Green Cards and the Location Choices of Immigrants in the United States, 1971-2000

David A. Jaeger

College of William and Mary and IZA

College of William and Mary

Department of Economics

Working Paper Number 29

May 2006

I thank Seth Sanders for comments on an earlier version and IZA for financial support while I worked on this paper. 
COLLEGE OF WILLIAM AND MARY

DEPARTMENT OF ECONOMICS

WORKING PAPER \# 29

May 2006

\title{
Green Cards and the Location Choices of Immigrants in the United States, 1971-2000
}

\begin{abstract}
This paper documents where immigrants who enter the U.S. with different types of visas ("green cards") choose to live initially and what determines those location choices. Using population data on immigrants from the Immigration and Naturalization Service from 1971 to 2000, matched to data on state characteristics from the Integrated Public Use Microsamples of the U.S. Census, I estimate conditional logit models with the 48 contiguous U.S. states as the choice set. Like previous researchers, I estimate that immigrants have a higher probability of moving to states where individuals from their region of birth represent a larger share of the state population, with relatives of legal permanent residents responding most to this factor. I also find that, in general, immigrants in all admission categories respond to labor market conditions when choosing where to live, but that these effects were the largest for male employment-based immigrants and, surprisingly, refugees.
\end{abstract}

JEL Codes: J61, J18, C35

Keywords: admission categories, immigrants, settlement patterns, conditional logit

David A. Jaeger

Department of Economics

College of William and Mary

P.O. Box 8795

Williamsburg, VA 23187-8795

djaeger@wm.edu 
Since 1971, approximately 25 million immigrants have entered the United States as legal permanent residents. These immigrants have tended to locate on both coasts and along the southern border, with labor market and fiscal impacts of immigrants concentrated in those areas. That immigrants tend to locate near the border might suggest that immigrants are relatively insensitive to economic conditions in the interior of the U.S. even though many come to the U.S. for economic reasons.

Given the continued large flow of immigrants that began in 1965 with the change in U.S. immigration law from a geographic quota system to one relying primarily on family reunification, the determinants of immigrant location choice should be important considerations in designing immigration policy. The capacity of the U.S. to absorb immigrants is potentially much greater if they are more likely to respond to disperse economic opportunities rather than clustering solely in "traditional" immigrant-receiving areas.

The literature on the determinants of immigrant locations in the U.S. provides mixed evidence on the responsiveness of immigrants to geographic variation in labor market conditions. Bartel (1989) found that the foreign-born tend to locate in metropolitan areas with large ethnic populations and that more highly educated immigrants tend to be less geographically concentrated than less-educated immigrants. She also found that immigrants are relatively insensitive to economic conditions, a result that has been frequently cited in the literature on the impact of immigration on the labor market outcomes of native workers (see Borjas 1999 for an overview). Dunlevy (1991), focusing solely on the location patterns of Caribbean- and Latinborn resident aliens, also found that new immigrants are attracted to locations with relatively large concentrations of similar immigrants. Bauer, Epstein, and Gang (2002) examined this issue further and found that Mexican immigrants respond both to recent flows as well as the stock of immigrants from their village when deciding where to locate in the U.S. They also presented some evidence that unemployment rates affect immigrants' choices, particularly for those who are in the U.S. illegally. Borjas (2001) found that immigrants are more responsive than natives to differences in economic conditions and "grease the wheels" of the labor market by bringing workers to where they can be used most efficiently.

In this paper I revisit the issue of location choice of immigrants entering the U.S. to reside permanently using data on nearly every legal immigrant to the U.S. between 1971 and 2000. Unlike past research, I stratify by one of the primary policy levers used to alter the 
character flow of the legal immigrant flow to the U.S.: green card categories. I also look at a much longer time frame than previous research. Because I have information on nearly every legal immigrant that has come to the U.S. since 1971, my samples are quite a bit larger than those used previously. Matching these population data on samples of the U.S. population from the 1970 through 2000 U.S. Censuses, I find that labor market conditions (measured by unemployment and expected wages) affect immigrant location choices across time and across admission categories, but are most important for where employment-related immigrants' location decisions. Like past research, I find that concentrations of similar immigrants (defined by region of birth) are also important determinants of where immigrants decide to live, particularly for relatives of past green card recipients.

The next section of the paper briefly discusses the admission categories that are used to determine eligibility for a foreign national to emigrate to the U.S. and which form the core the analysis in the paper. In Section III I then provide some descriptive statistics on the origin of immigrants in various admission categories and their destinations in the U.S. Section IV discusses the skills of immigrants in different admission categories. The stochastic choice model and the estimates of the parameters of that model for immigrants in different admission categories are presented in Section V while Section VI offers some conclusions.

\section{A Brief Overview of Admission Categories}

The Immigration and Naturalization Services Act of 1965 abolished national origin as the primary basis of U.S. immigration law and replaced it with a system based mainly on three objectives: reunite families, fill jobs with skilled or needed workers, and provide safe haven for refugees. Of these, the first is by far the most important and the majority of legal immigrants who enter the U.S. come in through this method. The law distinguishes between admission categories that have annual limits on the number of visas that can be issued and those that do not. Immediate relatives of U.S. citizens (spouses, parents, and unmarried children under 21) are not subject to quotas on the number of available visas while all other admission categories, or "green cards," are subject to annual quotas. Limits are imposed both by the type of green card and by

\footnotetext{
${ }^{1}$ So-called because the paper on which the documentation that showed the immigrant was a legal permanent resident of the U.S. was green, although now the card is predominantly white.
} 
the country of "chargeability," which is usually the immigrant's country of birth. Refugees and asylum seekers face different limitations than other visa categories.

While reuniting families, filling jobs, and providing safe haven have remained the primary goals of U.S. immigration policy, the absolute number of numerically limited green cards as well as the relative numbers in different categories have changed at various points since 1965. Most notably, the Immigration Act of 1990 increased both the total number of green cards and the relative number of employment-based green cards available. The "diversity" category was also introduced, with the objective of increasing the number of immigrants from countries that sent less than 50,000 individuals to the U.S. during the previous five years. ${ }^{2}$ These visas are allocated by a lottery; in 2005, the U.S. Department of State received 6.3 million eligible applications for 50,000 available diversity green cards.

In this paper, I divide the immigrant entrants into 7 primary categories: immediate family of U.S. citizens not subject to quotas (spouses, unmarried children under 21, and parents), family of U.S. citizens subject to quotas (unmarried children over 21, siblings, and married children), family of legal permanent residents (green card holders), employment-based, ${ }^{3}$ "diversity" visas, ${ }^{4}$ refugees and asylees, and a vestigial category of entrants from the Western Hemisphere. ${ }^{5}$ There are many different specific kinds of visas within each of these categories, but they represent the basic outline of U.S. immigrant policy. ${ }^{6}$

\footnotetext{
${ }^{2}$ While the initial set of countries from which diversity immigrants could come was relatively limited, since 1995 diversity visas have, in general, been open to individuals from most countries in the world. For example, in fiscal year 2007, only individuals from Canada, China (mainland-born), Colombia, Dominican Republic, El Salvador, Haiti, India, Jamaica, Mexico, Pakistan, Philippines, Poland, Russia, South Korea, and the United Kingdom (except Northern Ireland) are ineligible for a diversity visa.

${ }^{3}$ I include employment-creation, or "investor," immigrants in the employment-related category. The employmentcreation immigrant category was created in Immigration Act of 1990. "Investor" immigrants must agree to invest $\$ 1,000,000$ (\$500,000 in a targeted employment area) and create at least 10 jobs. Since the program's creation, there have been on average 446 immigrants per fiscal year who enter the U.S. with an employment-creation visa.

${ }^{4}$ Diversity entrants only appear after 1991.

${ }^{5}$ Prior to 1976, Western Hemisphere immigrants were not subject to the same admission categories as Eastern Hemisphere immigrants nor were they subject to per-country limitations, although the overall number of Western Hemisphere immigrants was limited after 1965. Thus, Western Hemisphere immigrants mainly appear in the other admission categories only after 1976.

${ }^{6}$ The one exception is formerly illegal aliens who were legalized as part of the Immigration Reform and Control Act (IRCA) of 1986. More than 2.6 million illegal aliens have been given green cards since 1989 under the IRCA
} 
The requirements to enter the U.S. vary by visa type, and because of this, we might expect the location choices of immigrants in different admission categories to vary as well. Family reunification immigrants must have a sponsoring relative already in the U.S., who files a petition with U.S. Citizenship and Immigration Services (CIS, formerly one of the constituent parts of the Immigration and Naturalization Service, or INS). Employment-based immigrants must, in general, already have a job in the U.S., and their prospective employer must file a petition with CIS for them to be admitted. In addition, for most employment visas, the U.S. Department of labor must certify that no qualified U.S. worker is available for the job. Unlike family-reunification and employment-based immigrants, diversity immigrants can have no prior connections to individuals or firms in the U.S. Because of this they provide, perhaps, the best measure of how immigrants respond to various factors that determine location choice. Refugees, in general, enter the U.S on temporary visas first and then can apply for legal permanent residence. $^{7}$

For immigrants who desire to enter under a visa category that is subject to a numerical limits, the immigrant may have to wait until an appropriate visa becomes available. The length of this wait can vary substantially by visa category and the immigrant's country of citizenship. For example, in May 2006, the "priority date" for individuals from the Philippines waiting to enter as a sibling of a U.S. citizen was 15 October 1983. This means that their application for admission to the U.S. had to be approved on that date for them to eligible for a visa of that type. For all other countries other than Mexico and India, the "priority date" for a visa for a sibling of a U.S. citizen was 1 January 1995 - still a substantial wait. Of course, immigrants may have available to them more than one potential sponsor, particularly for family-reunification visas, and may strategically choose which category under which to apply. Because I have no way of knowing who the potential sponsors are, I will not try to model this choice, but merely note that immigrants may have more than path of legal entry to the U.S.

amnesty, with all but approximately 35,000 legalizations occurring between 1989 and 1992. Data on IRCA legalizations are not available in the INS data files.

${ }^{7}$ Both refugees and asylees are granted admission to the U.S. because they fear persecution, injury, deprivation, or death if they were return to their home country. Refugees and asylees differ only in where they seek protection by the U.S. Refugees are those who seek protection while outside of the U.S. while asylees are those who seek protection while already in the U.S. I will refer to both groups "Refugees" for the rest of the paper. 
Two final distinctions made by U.S. policy should be noted. First, the immigrant whose relationship to an individual or firm in the U.S., refugee status, or lottery success allows them to enter the U.S. is considered the "primary" immigrant. But, in general, their immediate family (spouse and children) may also enter the U.S. at the same time. If they do, they are considered "beneficiaries" of the primary immigrant because their visa status is a "derivative" of the status

of the primary immigrant. ${ }^{8}$ Second, individuals may apply for legal permanent residency while they are either inside or outside of the U.S. Those who are already in the country must "adjust" their status from temporary (e.g. a student, J, or temporary employment, $\mathrm{H}$, visa) to permanent. Those who are outside of the U.S. enter the U.S. as "new" immigrants, although, of course, they are very likely to have ties to individuals or firms in the U.S. For the regression analysis later in the paper, I will examine the location choices of newly-arriving primary immigrants to minimize potential endogeneity issues.

\section{Data}

Data on the population of immigrants admitted legally to the U.S. is available in the various Immigrants Admitted to the United States files produced by the former Immigration and Naturalization Service (now split into several sub-agencies of the Department of Homeland Security). I use all of the available data from 1971 to 2000 for the descriptive statistics in the paper. The key variable available in the INS data, not available in other data sources such as the Census or Current Population Survey, is the type of visa under which an immigrant was admitted to the U.S. There is a substantial amount of detail available about visa type in the INS data (reflecting the complexity of U.S. immigration law), but to simplify the analysis and provide consistency over time, I divide the immigrant population into the 7 broad visa categories discussed above: immediate relatives of U.S. citizens not subject to quota limitations, other family of U.S. citizens subject to quota limitations, family of resident legal aliens, employmentrelated, diversity (for the years after 1991), Western Hemisphere immigrants (for the years prior to 1977), and refugees, The descriptive graphs also present a residual category of "other." Categorization of the detailed visa types available in the INS data into these 7 areas generally

\footnotetext{
${ }^{8}$ Both of these words are sometimes used to describe the status of non-primary immigrants.
} 
follows the classification outlined in the documentation to the 2000 INS data file (U.S. Department of Justice 2000). The INS data area made available by fiscal year but I present results by calendar year. ${ }^{9}$

In this paper I use states as the geographical unit of analysis. I define the geography this way for a variety of reasons. First, this allows me to examine the behavior of all of the immigrants who locate in the contiguous 48 states, rather than excluding those who live outside of some arbitrary number of large cities. ${ }^{10}$ Second, inclusion of all 48 contiguous states provides a "control" group of states without many previous immigrants that are partially absent from analyses that use only large metropolitan areas (e.g. Bartel 1989). Using a choice set of 48 states is both computationally feasible in the conditional logit analysis described below while also providing a substantial amount of variation in the right hand side variables. Third, and most important, state boundaries are constant and permit direct comparisons over time without concerns about how differing definitions of metropolitan areas might alter the descriptive statistics or the estimated coefficients of the models. In the INS data, the observed "location" is the address to which the immigrant's green card will be mailed. While this may or may not be the exact location in which the immigrant lives, for my purposes as long as the immigrant receives their green card in the state in which they do or will reside, there will be no mismeasurement of their location.

For the regression analysis, information on state characteristics (e.g. unemployment, wages, concentrations of the foreign-born) is drawn from the Integrated Public Use Microsamples of the U.S. Census, or IPUMS (Ruggles, et al., 2004) from 1970, 1980, 1990, and 2000. In all four years, the Census provides a snapshot of the U.S. on 1 April of that year. These data are then matched to the information on individual immigrants from the INS data. To estimate the stochastic choice models, I use data on non-refuee immigrants who entered from June-December 1971 (the earliest data available), May-December 1980, May-December 1990, and May-December 2000, matched to data from the 1970, 1980, 1990, and 2000 IPUMS, respectively. Thus, I measure the location decisions of immigrants just after the labor market conditions and socio-demographic distributions are observed. I estimate the models for non-

\footnotetext{
${ }^{9}$ The fiscal year was July-June for years prior to 1976 and October-September for fiscal years after $1976 . \quad$ There is also a file for the "transition quarter" of July-September 1976.

${ }^{10}$ I treat Washington, D.C. as part of Virginia for the analysis.
} 
refugees only using "new" immigrants who were (presumably) not in the U.S. at the time of the Census. These two restrictions reduce, as much as possible, the possibility of endogeneity bias, in the sense that the observed information about a state would include the immigrant herself, while still giving a strong temporal link between the observed U.S. conditions and the location choices of immigrants.

Because refugees are observed only when they change their status from temporary to permanent, I must treat them differently when defining the individuals in regression samples. ${ }^{11}$ The INS data record only the year, but not the month, in which "adjustees" first entered the U.S. on a temporary visa. To avoid endogeneity issues, I match the refugee population to the 1980 Census data include individuals who first entered the U.S. in 1981 and received their green card in 1981 or 1982; the refugee population matched to the 1990 Census is defined similarly. The refugee population matched to the 1970 Census data includes "new" refugees who received their green cards in the latter half of 1971 or the first half of 1972 as well as "adjusting" refugees who first entered the U.S. in 1971 and received their green card between 1971 and 1974. Because the INS data are available only until fiscal year 2000 (October 1999 to September 2000), I do not have data on any refugees who I am certain entered the U.S. after the Census data of 1 April 2000. I must also assume that the location of a refugee when entering U.S. was same as the location when they received their green card. The populations are chosen to limit the amount of time between initial entry and when I observe the immigrant's location. Because of these data limitations, the temporal and perhaps spatial link between the observed conditions in the U.S. and the location choice of refugees is not as close as for other admission categories.

I impose two other restrictions on the population used for the regression analysis. First, I limit the data to individuals who were 25 to 60 years old at the time they received their green card and who did not report their occupation being a student, to insure that they have some potential connection to the labor market. Second, I conduct the regression analysis only on "primary" immigrants - that is, the immigrant whose status permitted their immediate family (if any) to enter the U.S. This abstracts from issues of intra-household correlation of unobserved

\footnotetext{
${ }^{11}$ Prior to 1976 , some refugees were permitted to enter the U.S. with a green card in hand rather than waiting one year with a temporary visa before applying for one.
} 
characteristics and insures that only one individual per family is used for the regression analysis. $^{12}$

\section{How Many Immigrants? From Where? To Where?}

The flow of immigrants to the U.S. since 1971 has not been constant; it peaked in the mid-1990s then declined until 2000. Figure 1 shows the flow of immigrants from 1972 to 1999 (the first and last calendar years in which full data are available) in the seven admission categories outlined above. These figures include both "new" immigrants as well as those who were adjusting their status from a temporary status to permanent legal residency. The number of immigrants admitted to the U.S. more than doubled between 1972 from just less than 400,000 to a peak of about 870,000 in 1996 , and then decreased to around 625,000 in $1999 .^{13}$

Figure 2 presents the share of each green card group in total immigrant admissions from 1971 to 2000 . Immediate relatives of U.S. citizens, who are not subject to quota limitations, are always the largest group, with a share that has been generally increasing from around 25 percent in the early 1970s to around 40 percent in the late 1990s and 2000. The number of other relatives of U.S. citizens, which is subject to a quota, has fluctuated somewhat, but has usually remained between 12 and 18 percent of the total. Not surprisingly, given the increasing number of green card holders, the share of relatives of legal permanent residents increased fairly substantially from the early 1970s (when it was around 10 percent) to the mid-1980s (when it was around 20 percent). The share of this group then declined somewhat in the 1990s and by 2000 was around 15 percent. Overall family-related admissions (relatives of U.S. citizens and legal permanent residents) have been at least half of the total flow of immigrants since 1973, at times surpassing 70 percent of the total flow. This has been in spite of the legislative changes in 1990 that increased the number of employment-based visas and introduced employment-creation

\footnotetext{
${ }^{12}$ Unfortunately, one cannot identify members of the same family entering the U.S. to link the "primary" immigrant to his or her "beneficiaries."

${ }^{13}$ Note that these statistics are for the calendar year, not the federal government's fiscal year, and so will not match exactly the statistics reported by the Immigration and Naturalization Service. They also do not include amnesty legalizations authorized by the 1986 Immigration Reform and Control Act. After 2000, the flow of immigrants increased again. From fiscal years 2000 to 2004, the number of immigrants admitted to the U.S. averaged about 925,000, with a peak of just over 1,000,000 in 2002 (United States Census Bureau 2006, Table 6).
} 
and "diversity" green cards (winners of the visa lottery). Reflecting those changes, employmentbased entrants (including those entering as beneficiaries of the job holder) increased from less than 10 percent of the total in 1971 to a peak of 18 percent in 1992, falling back to an average of around 11 percent from 1995 to 2000. Refugee admissions have fluctuated substantially depending on the conditions around the world that warrant awarding refugee status, from a minimum of 6 percent in 1999 to a maximum of 28 percent in 1982. The number of diversity admissions has remained fairly constant at around 50,000 per year since their introduction in 1992, but as a share have fluctuated between 4 and 8 percent of the total.

\section{Where did the immigrants come from?}

Past research (e.g. Bartel 1989, Jaeger 2000, Bauer, Epstein, and Gang 2002) has shown that concentrations of similar immigrants are important determinants of he location choice. To the extent that immigrants in different admission categories originate in different countries, we would expect that settlement patterns would also differ across those categories. Given the different requirements of the various types of green cards, it is not surprising that immigrants entering the U.S. under different visas come from different areas of the world. In Figures 3 through 8, I present the share of green card recipients from each of 13 regions-of-origin in each of the 7 primary admission categories. ${ }^{14}$ Relative to other visa groups, immediate relatives of U.S. citizens (Figure 3) have had a roughly constant distribution across the 13 regions of origin over time. The biggest changes have been an increase in entrants from Eastern Europe after 1985, an increase in the share of entrants from Mexico and Central America after the mid-1990s, a decrease in the share of those from Southeast Asia since 1975, secular decreases in the share of immigrants from Western and Southern Europe, and secular increase in the share from the Caribbean.

Relative to immediate family of U.S. citizens, both family of U.S. citizens subject to quotas (Figure 4) and relatives of legal permanent residents (Figure 5) have experienced much greater shifts in the distribution across region-of-origin. For relatives of U.S. citizens, the largest change comes after 1975, when immigrants from the Western Hemisphere (i.e. from North

\footnotetext{
${ }^{14}$ The regions of origin are: Western Europe, Southern Europe, Eastern Europe, North America excluding Mexico, Mexico and Central America, South America, Caribbean, Africa, Middle East, Southwest Asia, Southeast Asia, East Asia, and Oceania. See the Data Appendix for more information about which countries are included in each region.
} 
America, Mexico and Central America, the Caribbean, and South America) were required to enter the U.S. through the "normal" admission categories from which they had previously been exempt. At the same time that the share of Western Hemisphere immigrants was increasing, that of immigrants from Western and Southern Europe was decreasing. Relative to the 1970s, the share of Eastern Europeans and Southeast Asians increased in the early and mid 1980s. Since 1985, however, the shares from the various country groups have been quite stable. This has not been the case for relatives of legal permanent residents. As with numerically limited relatives of U.S. citizens, there was a large increase in the share of immigrants from Mexico and Central America and South America after Western Hemisphere immigrants were required to enter under "normal" categories after 1976. What is more striking, however, is the substantial increase in the share of immigrants from Mexico and Central America after 1990. The timing of this large increase coincides with the legalization of illegal aliens following the 1986 Immigration Reform and Control Act (IRCA), which were largely of Mexican and Central American origin, suggesting that the overall impact of IRCA on the number of legal immigrants was substantially greater than just the 2.8 million who were admitted directly.

The change in the region-of-origin composition after 1976 is also evident in the distribution of employment-based green cards. Figure 6 shows the time pattern of these flows. On the whole, the shares are fairly stable after 1980, with a notable spike in 1993 of East Asians and an increase in Eastern Europeans following the fall of the Iron Curtain.

The region of origin distributions of Western Hemisphere and diversity immigrants are shown in Figure 7. ${ }^{15}$ The most notable feature here is the change in the composition of the flow of diversity immigrants in 1995. This is because in 1995 the countries from which diversity immigrants could come was substantially opened up; prior to 1995, citizens of Ireland and Poland were main beneficiaries of the diversity visa program.

The origin of refugees is determined both by political and humanitarian situations around the world. Figure 8 presents the region-of-origin shares of refugees. In the early 1970s refugees were predominantly from Cuba. Following the end of the Vietnam War, there was an increase in the share of refugees from Southeast Asia and since roughly 1980 there has been a steady

\footnotetext{
${ }^{15}$ The small number of European-born immigrants that appear for Western Hemisphere visas are due to individuals who were born in Europe but who could be "charged" to a Western Hemisphere country, presumably because they had become citizens of a Western Hemisphere country.
} 
increase in the share of refugees from Eastern Europe, particularly just prior to, and after, the fall of the Soviet Union.

Where did the immigrants go?

It is well known that immigrants tend to be more geographically concentrated than natives. In Figure 9, I present Herfindahl indices of concentration for the flow of immigrants to the U.S. (measured annually from 1971 to 2000 in the INS data) and the stocks of foreign- and native-born individuals (measured at 10 year intervals from 1970 to 2000 in the IPUMS data). The Herfindahl index is give by

$$
H_{i t}=\sum_{j=1}^{48} \theta_{i j t}^{2}
$$

where $\theta_{i j}$ is the share of group $i$ that is located in state $j$, in year $t$, with $0 \leq H_{i t} \leq 1$. Smaller values of $H_{i t}$ indicate lower degrees of geographic concentration. The geographic concentration of natives is essentially constant, while that for both the flow of immigrants and the stock of the foreign-born peaks around 1990 and then declines by 2000. While the flow of immigrants appears to be less geographically dispersed than the stock of the foreign-born in 1970 and 1980, but they were essentially concentrated to the same degree by 1990 and 2000.

Figure 10, for family reunification visas, and Figure 11, for all other admission categories, repeat this exercise. Immediate family of U.S. citizens (mostly spouses) are, in Figure 10, less concentrated than other relatives of U.S. citizens, but are (in comparison to Figure 9), still substantially more concentrated than the total native-born population. Relatives of legal permanent residents are more concentrated than the relatives of U.S. citizens, which is (again) not surprising, given that the foreign-born are more concentrative than the native born. As with the overall flow of immigrants, the concentration of employment-based immigrants peaked between 1985 and 1990 and then has declined somewhat. This increase in geographic dispersion is also evinced by diversity immigrants who have grown more disperse each year since the visa lottery was introduced. Refugees have exhibited a high degree of variability in their degree of geographic concentration, reflecting the sometimes-sudden changes in the country-of-birth composition of refugees. Overall, however, refugees have also grown more disperse since 1990. 
Western Hemisphere immigrants were relatively highly concentrated compared to other admission categories.

The conventional wisdom is that immigrants locate primarily in 6 states: California, New York, Florida, Texas, New Jersey, and Illinois. While this has remained roughly true during the 30 years under examination in this paper, the Herfindahl indices presented above allude to substantial variation across admission categories in the degree to which these 6 states receive the bulk of immigrants.

For reference, I present maps in Figures 12 and 13 of he geographic distribution across states of the stock of the native- and foreign-born populations, respectively, from 1970 to 2000 . Each break point between categories is twice the previous breakpoint, i.e. the categories are $[0,0.25),[.25,0.50),[.50,1.00)$, etc. to $[8,16)$, and $[16,100)$. A few patterns can be discerned from these figures. As was shown in Figure 9, the foreign-born are more geographically concentrated than natives. Between 1970 and 2000, both populations have shifted somewhat away from northern states like New York and Michigan. While the "Big 6" states continue to be important locations for the foreign-born, they have also started moving to non-traditional destinations like Arizona, Nevada, North Carolina, and Utah. Unlike in 1970, Texas and Florida are now as roughly as important locations for the foreign-born as New York.

Figure 14 through 19 show the distribution of the cumulative 10 year flow of immigrants in the seven admission categories for each of the three decades available in the INS data. Like the geographic distribution of natives, the location choices of immediate relatives of U.S. citizens, shown in Figure 14, have also changed relatively little in the 30 years between 1971 and 2000. The Southeast was less popular as a destination in 1991-2000 than in 1971-2000 and the lower Mississippi River valley also seems to be less popular, but these changes were small and overall the distributions look remarkably similar. The same could also be said of other relatives of U.S. citizens, shown in Figure 15, except for a slight shift towards the southwestern states.

There have been substantial changes, however, in the location choices of relatives of legal permanent residents, as shown in Figure 16. Given the large increase in the share of this group coming from Mexico and Central America, as shown in Figure 5, it is perhaps not surprising that Texas has becoming an increasingly important destination. There has also been a distinct shift towards states relatively near to Texas and California (Arizona, New Mexico, Nevada, Utah, Oklahoma, Kansas, and Colorado). 
Employment visa immigrants, shown in Figure 17, are less concentrated than the family of legal permanent residents and non-immediate family of U.S. citizens. In all three periods, they are more likely to locate in the upper Midwest and the Southeast than either family of legal permanent residents or non-immediate family of U.S. citizens. The most notable changes among employment immigrants are shifts away from Illinois after 1980 and New York after 1990.

Figure 18 show that Western Hemisphere immigrants were highly concentrated in the "Big 6" states, and avoided locating in much of the country. Diversity immigrants are less highly concentrated, but still much more concentrated than natives or immediate family of U.S. citizens, with the "Big 6" figuring prominently in their location choices.

Refugees were approximately similarly geographically distributed as non-immediate family of U.S. citizens. They were somewhat more likely to locate in the Southeast in 1991-2000 than in 1971-1980, and were somewhat less likely to locate in Louisiana and Arkansas. Washington is also now somewhat more popular. New York is less popular in the middle decade as a destination than in the first and last. But, over the 30 year period, the changes in the geographic distribution of refugees have been relatively minor.

Taken as a whole, these figures indicate that there are substantial differences in location choices among immigrants in different admission categories and, to some extent, over time within admission category. This is due, in part, to the different countries of origin, and likely also to the varying skills that immigrants in different categories bring to the U.S.

\section{Green Cards and the Skills of Immigrants}

While concentrations of individuals from their country of birth are likely to be an important determinant of where an immigrant decides to live, Bartel (1989) has noted that the more highly educated foreign-born tend to be more geographically disperse than those with lower levels of education. Skills and their interaction with labor market conditions may also play an important role in determining location choice. Unfortunately, the INS data do not contain information on educational attainment. They do, however, contain information on occupation, age, and country of origin, all of which should be related to the human capital that immigrants bring to the U.S. I use this information to calculate the probability that the immigrants in the INS data are in each of three broad skill categories by pooling data on the foreign-born from the 
1980 and 1990 Censuses and estimating an ordered logit with the three choices for the dependent variable: less than 12 years of schooling, 12-15 years of schooling, and 16 years of more of schooling. In addition to indicator variables for occupation, the regressions included indicators for each of the 13 region-of-origin groups, an indicator for being married, and a quadratic in age. ${ }^{16}$. I estimated the model separately for men and women and to abstract from schooling and retirement issues, I dropped individuals whose were in school as well as those who were less than 25 years or greater than 60 years old. More information on the results of the ordered logit regressions can be found in the Data Appendix.

To evaluate the changing skill composition of immigrants within admission categories, I plot the distribution across the three skill groups in Figures 20 through 25. For each year, I summed the predicted probability of being in each of the three skill groups across individuals; i.e. each individual contributed some fraction to each of the three skill group shares. This procedure amounts to assigning fixed weights to occupation, region-of-origin, age, and marital status based on the coefficients of the mens' and womens' ordered logit regressions. Changes over time in the imputed skill distribution of immigrants in each admission category derive completely from changes in the occupational, region-of-origin, age, and marital status distributions.

For family of U.S. citizens, shown in Figures 20 (immediately family) and 21 (other relatives), the distribution across skill groups has changed relatively little over time. Roughly 22 percent both immediate and other relatives of U.S. citizens were in the lowest skill category (high school dropout equivalents). For immediate family of U.S. citizens this share declines substantially between 1998 and 2000, to 15 percent. About 30 percent of immediately family and 35 percent of other family were in the highest skill category (college graduates), although this increases for immediately family, ending at 37 percent in 2000. Individuals who enter as family of legal permanent residents have shown a continual decline in average skill (Figure 22). In 1971, 40 percent of family of legal permanent residents was imputed to be in the highest skill category while in 2000, only 23 percent were. Similarly, in the mid 1970s, only about 12 percent

\footnotetext{
${ }^{16}$ Occupation codes vary across time in the INS data and between the INS and IPUMS data. The "lowest common denominator" for the occupation codes are those used in the INS data between 1983 and 1998. After combining a few occupations with small cells and dropping students, there are 18 occupation categories, which are used to predict skill levels.
} 
were imputed to be in the lowest skill group, while in 1997, 35 percent were (although this fell to 23 percent by 2000$)$.

Since most (primary) employment visa immigrants are required to be high-skilled, it is not surprising that Figure 23 shows that a much larger share of employment-based immigrants are highly skilled than other groups. Roughly 50-60 percent of this admissions group is in the high skill group while another 30-40 percent are in the middle skill group. Between 5 and 15 percent are in the lowest skill category. The average skill level declined somewhat in the late 1980s but since then has increased. Diversity immigrants are also required to have at least a high school diploma, and the skill distribution in Figure 24 reflects this. Western Hemisphere immigrants were generally low-skilled, with less than 20 percent in the high skill category.

The skills of refugees, shown in Figure 25, have improved somewhat since the 1970s, when roughly one third were in the low-skill group, while more recently this share has been closer to 20 percent. Also, in the late 1980s the share allocated to the high skill group increased substantially.

While these skill measures are relatively coarse, they do roughly capture the administrative requirements of the various admission categories. Given the differing skills and region-of-origin across the various admission categories, we might expect that different groups will respond differently to changing economic and socio-demographic conditions when deciding where to locate in the U.S.

\section{Admission Categories and Determinants of Immigrants' Location Choice}

What determines where immigrants decide to live? Certainly proximity to kin and country-specific networks play an important role. While the past evidence is mixed, it is almost certainly true that labor market conditions affect where immigrants decide to live, even for family-reunification entrants. In this section I estimate regressions that attempt to estimate how various socio-demographic and labor market factors influence where immigrants live.

I employ a standard discrete choice model for the analysis. This framework is similar to those employed by Bartel (1989), Jaeger (2000), and Bauer, Epstein, and Gang (2002). I assume that immigrants have an additive stochastic utility function of the form

$U_{i j}=\mathbf{L}_{j} \Theta+\mathbf{X}_{i j} \Pi+\varepsilon_{i j}$ 
where $\mathbf{L}_{j}$ is a vector of state characteristics (including, potentially, state fixed effects) and $\mathbf{X}_{i j}$ is a vector of interactions between state and individual characteristics. I assume that immigrants choose the location that maximizes their expected utility. If the stochastic term $\varepsilon_{i j} \sim$ i.i.d. Weibull, the parameters of the model can be estimated using a conditional logit model (McFadden 1984). The probability of individual $i$ choosing to live in state $l$ is then

$$
P\left(y_{i}=l\right)=\frac{\exp \left(\mathbf{L}_{j} \Theta+\mathbf{X}_{i j} \Pi\right)}{\sum_{j=1}^{48} \exp \left(\mathbf{L}_{j} \Theta+\mathbf{X}_{i j} \boldsymbol{\Pi}\right)}
$$

where $y_{i}$ is individual $i$ 's location choice and there are 48 states in the choice set. This analysis requires estimation using $48 \times N$ observations, where $N$ is the number of individuals in the data. The marginal effect of a change in some characteristic, $z$, of a state, on the probability that an immigrant will choose to live in that state is just the derivative of (2), i.e.

$$
\frac{\partial P\left(y_{i}=l\right)}{\partial z_{l}}=\left[P\left(y_{i}=l\right)\left(1-P\left(y_{i}=l\right)\right)\right] \theta_{z} .
$$

While the effect of any covariate will vary with $l$ (because the share of immigrants choosing to live in any given state is different), I present "average" effects of $z$ on $P\left(y_{i}=l\right)$, i.e.

$$
\frac{\partial \hat{P}\left(y_{i}=l\right)}{\partial z_{l}}=[(1 / 48)-(1-(1 / 48))] \hat{\theta}_{z}
$$

The variables in $\mathbf{L}$ and $\mathbf{X}$ are designed to capture a variety of state characteristics that may affect both the pecuniary and non-pecuniary aspects of immigrants' utility. I include two variables to measure labor market conditions: the state-level unemployment rate, and the immigrant's expected log wage. The expected wage is calculated by taking a weighted average of $\log$ median wages in each of the skill categories discussed earlier, observed in the IPUMS data, with the weights being $\hat{P}(S=k)_{i}$, derived from the results of the conditional logit estimation. ${ }^{17}$ The "expected" wage varies both by state and by the characteristics of the immigrant.

It has been thoroughly documented that immigrants are drawn to locations with concentrations of immigrants who are like them (e.g. Bartel 1989, Dunlevy 1991, Jaeger 2000, Bauer, Epstein, and Gang 2002). This may be due to network externalities, herd effects, or linguistic considerations. For sample-size reasons in the IPUMS (particularly in low-immigrant

\footnotetext{
${ }^{17}$ I use median rather than mean wages to avoid issues of different nominal topcode values across Censuses.
} 
states in 1970 and 1980), I measure immigrant concentrations using region of birth rather than country of birth. I measure immigrant concentrations in three ways. First, I include the share of the immigrant's region of birth group in the state population. This controls for the relative size of the potential network and, to some extent, for the size of linguistic community available to the immigrant. Second, as a measure of the absolute size of the population of an immigrant group in a state, I include the share of the total population in the U.S. of the immigrant's region of birth that lives in the state. ${ }^{18}$ And, finally, I include the overall foreign-born share of the state. Immigrants may prefer, for cultural and economic reasons, to live in areas with more "international" neighbors, without regard to their country of origin. Bauer, Epstein, and Gang (2002) argue that there are diminishing returns to the size of immigrant networks and so their "magnetic" effect should also show diminishing or even declining returns. I therefore include both a linear and quadratic term for all three of the immigrant concentration measures. I also include the natural log of the state's population and (in models without state fixed effects) the natural log of the land area of the state, which together control for the population density.

Many immigrants still maintain ties with their "home" country even after receiving a green card. To proxy for costs of visiting kin (or perhaps returning home), I include a quadratic in the straight-line distance from the most populous city in the immigrant's country of birth to the geographic center of the state. ${ }^{19}$ In addition, Cragg and Kahn (1997) show that amenities like climate are important determinants of migration propensities. I include in the models a quadratic in the absolute difference between the average temperature in the state and the immigrant's country of birth and a quadratic in the absolute difference between the average annual precipitation in the state and the immigrant's country of birth. ${ }^{20}$

I first estimate models where I pool the four samples from the INS data matched to IPUMS data from 1970, 1980, 1990, and 2000 and include state fixed effects. These fixed effects control for time-invariant characteristics of the state, e.g. the land area of the state, and

\footnotetext{
${ }^{18}$ Note that this is just the population of a region of birth group in a state divided by the total population of that region of birth group in the U.S. Since this denominator is the same for all states, the variable measures the effect of the absolute size of the group, but in a way that permits easier comparison to the other immigrant concentration variables.

${ }^{19}$ The Data Appendix discusses how this distance was calculated in greater detail.

${ }^{20}$ Note that because neither distance nor weather rely on the IPUMS data, I use the actual country of birth rather than the general region of birth.
} 
the "gateway" effects of places like California and New York, which naturally attract immigrants because they are on the coasts. In addition fixed effects capture the "initial" endowment of immigrants that determined where past migrants chose to live. Identification with state fixed effects comes from within-state variation over time in the covariates

Given the extremely large sample sizes in these regressions it is prudent to be conservative with the nominal level of significance when conducting hypothesis tests. I will use a nominal one percent level when discussing statistical significance, giving a nominal nonrejection region of $(-2.5758,2.5758)$ for a two-tailed test that the parameter in question is equal to zero.

Table 1 presents results of estimating (3) on the population of "primary" male immigrants. Entries in the table are marginal effects of a change in the characteristic of state $j$ on the probability that an immigrant will locate in state $j$, evaluated at the "average" probability of location (i.e. $1 / 48=.0208 \overline{3}$ ), per equation (5). Recall that the population used for the estimation is limited to individuals who were 25 to 60 years old at the time that they received their green card and who, except for refugees, are newly-arrived in the U.S.

Focusing first on labor market conditions, I find that they have mixed effects on the location propensities of family reunification immigrants. For all three family-reunification groups, the unemployment rate is not statistically significant at the one percent level while expected log wages have a strong positive effect for immediate relative of U.S. citizens and a marginally statistically significant and positive effect for relatives of legal permanent residents. For other relatives of U.S. citizens, higher wages negatively affect the probability of location.

For employment-based immigrants, higher unemployment rates have a negative and statistically significant effect on location probabilities, while wages have a positive and statistically significant effect. This suggests that employment immigrants locate in places with better labor markets, ceteris paribus. Because employment immigrants must normally have a job and be sponsored by a firm, interpreting these coefficients as purely causal effects of the labor market on the immigrants choices is somewhat problematic. What the estimates most likely reflect is the actions by firms in high-wage, low-employment states. When labor markets are tight, firms will be more likely to look outside of the U.S. for labor. That the region-of-birth variables are also significant suggests that when firms decide to look outside of the U.S., they may look for immigrants who are similar to those that already work for the firm. 
Government or private agencies often resettle refugees, so it is somewhat surprising that expected wages are even more important in determining location for them than for employment immigrants. For refugees the unemployment rate is also perversely signed and statistically significant.

Broadly speaking, the results confirm the previous literature that finds that concentrations of similar immigrants have a magnetic effect on immigrants' location choices. This is true for all family-unification groups with two of the three measures of immigrant concentrations, i.e. the percentage of the state that is from the immigrant's region-of-birth, and percent of the total U.S. population from the immigrant's region of birth that is living in the state. Of these two, the former is much more important. This suggests that immigrants would prefer a smaller state in which their country folk make up a larger percentage even if there are other states that larger absolutely numbers of individuals born in the same region as they were. Immigrant concentrations are more important for refugees than for either employment or family reunification immigrants. The magnitude of the third concentration variable, the percent of foreign born in the state population is much smaller than the other concentration variables, except for employment-based immigrants. This suggests that there areas of the country that are "immigrant-hiring" and those that are not. Lastly, given that the "Big 6" are populous states, it is not surprising that immigrants are estimated to locate in states with larger populations. This is likely due to immigrants' preferences for urban areas, where it is easier for them to establish employment and linguistic networks. The effect of population is strongest for employment immigrants, followed by relatives of legal permanent residents, and family of U.S. citizens. Population size does not affect the location probabilities of refugees.

The geographic and weather variables have differing effects across the admission categories. Distance has a negative effect for all groups (even though the coefficients on the quadratic terms are positive, over the relevant range the net effect of both variables is negative), but this is largest for relatives of legal permanent residents and smaller and statistically insignificant for refugees. The weather variables are of little quantitative importance and are often statistically not significant.

I repeat the same estimation for immigrant women in Table 2. Here the labor market effects are sometimes perversely signed, statistically insignificant, or both. Perhaps most puzzling is the negative and relatively large coefficients on expected wages for employment 
immigrants. Even though the population used for the estimation is primary immigrants, the location choices of female immigrants may be more likely to be a joint decision or affected more by their spouse's labor market possibilities than those of male immigrants. ${ }^{21}$ Only for refugees do the coefficients on the labor market variables have the expected signs and are statistically significant.

As with men, the share of the state's population that comes from the immigrant's region of birth is the most important of the three immigrant concentration variables. Distance from the "home" country is a more important determinant of location for family of legal permanent residents than for the other admission categories.

In general, across all 10 groups for men and women, I find confirmation of Bauer, Epstein, and Gang's (2002) results that the magnetic effects of immigrant concentrations have diminishing effects, although the coefficients on the quadratic terms are generally not large enough to lead to an inverted U-shape over the relevant ranges of immigrant concentration variables.

In Tables 3 through 6, I present estimates of the same model, with the addition of $\log$ (state land area) as a regressor and without state fixed effects, for immediate family of U.S. citizens, other family of U.S. citizens, family of legal permanent residents, and employment immigrants, respectively. In each table, I estimate the models separately for each of the four years under examination $(1971,1980,1990$, and 2000) and for men and women. Unlike the models in Tables 1 and 2, these are identified by both cross-state (over time) and within-state variation in the regressors. The within-state variation comes from having immigrants from different regions- and countries-of-birth as well as different occupations. In general, I find that the coefficients for men and women are remarkably similar within year and admission category.

Taking the results as a whole, I conclude that labor market conditions do significantly affect location choices across all four groups, with immigrants choosing higher-wage, lowerunemployment areas. Labor market conditions are most consistently important for employmentbased immigrants, where the unemployment rate, in particular, has a much larger effect than for other groups. The magnitude of the coefficients on the labor market variables, while changing somewhat from decade to decade, are fairly constant over time within admission category.

\footnotetext{
${ }^{21}$ That labor market conditions are more important for the male spouses of female U.S. citizens than they are for female spouses of male U.S. citizens suggests that, perhaps, female immigrants are more likely than their male counterparts to marry for love than for money.
} 
Given these results it is hard to argue, as Bartel (1989) does, that labor market conditions do not influence where immigrants decide to live. The results here are much more consistent with those of Borjas (2001), who found that immigrants are more sensitive than natives to labor market conditions when deciding where to live. That the results are fairly similar across decades, while relative economic conditions across states were changing, suggests that the results are not just picking up an artifact of low unemployment rates in California (for example) at one point in time.

Examining the immigrant concentration variables, I find strong evidence that these are more important for the family reunification groups than for immigrants entering under an employment visa. As in the models with fixed effects, the regional of birth as a share of the state population is the most important of the three immigrant location variables for all groups. As well, for all four admission categories, the coefficients on the share of the state's population from the immigrant's region of birth are smaller in 1990 and 2000 than they are in 1971 and 1980, suggesting that immigrants started seeking "non-traditional" locations during the during the last 20 years.

With the geographic and weather variables, as with the pooled fixed effects models, distance from country-of-birth is most important for relatives of legal permanent residents and least important for employment immigrants. The coefficients are fairly similar over time, except that for some groups the linear and quadratic terms switch signs in 1971. For all groups the coefficient on $\log$ (state population) is positive and for all groups except immediate family of U.S. citizens the coefficient on $\log$ (state land area) is negative. This is the pattern we would expect, ceteris paribus, if immigrants prefer to live in states with a higher population density (like New Jersey). Because the coefficients on both variables are positive for immediate family of U.S. citizens, it would appear that they to prefer to live in less dense areas. The sizes of the coefficients on the weather variables are generally quite small and of varying signs, although for some groups in some years they are statistically significant.

I only observe Western Hemisphere and diversity immigrants in 1971 and 2000, respectively, and so cannot include them in the pooled analysis with state fixed effects. In Table 7, I present results from estimating the now-familiar model on these two groups. They both provide, in some sense, a better test of the hypothesis that labor markets matter in addition to network and kinship effects, because individuals in neither group needed a formal tie to the U.S. 
prior to entering the country. Diversity immigrants, in particular, were chosen at random, and had a very low probability of actually winning the visa lottery. Their arrival in the U.S. can therefore be seen almost as a natural experiment, at least conditional on having applied for the lottery. Western Hemisphere and particularly diversity immigrants are substantially less unconstrained in their choice set than immigrants entering with other types of green cards.

For both groups, I find that labor market conditions are important determinants of their location choice. In particular, for diversity immigrants, higher wages in a state positively affect the probability of an immigrant locating there while higher unemployment rates deter immigrants from location there. For both men and women these effects are statistically significantly different from zero. This is perhaps the cleanest test and clearest refutation of Bartel's (1989) assertion that labor markets are relatively unimportant in determining where immigrants live.

Immigrant concentrations are much more important for Western Hemisphere immigrants than for diversity immigrants, reflecting, perhaps that they come from relatively few countries. Both groups, however, prefer to locate closer to their country-of-origin than not. Both groups also appear to prefer less densely populated states. As with other groups, weather matters comparatively little.

Lastly, Table 8 presents estimates from the model for refugees in 1971, 1980, and 1990. As with the pooled fixed effects models, I find very strong evidence that refugees locate in areas with good labor markets. These effects were strongest in 1971 for men and in 1971 and 1980 for women, but in all years the magnitude of the coefficients on the labor market variables are similar to those for employment-based immigrants. The impact of immigrant concentrations was stronger for both men and women in 1980 and 1990 than in 1971. Effects of the other variables were roughly constant over time and consistent with other groups.

\section{Conclusions}

This paper comprehensively examines the determinants of location choice of legal immigrants between 1971 and 2000. From the preponderance of data and coefficients, a fairly clear picture emerges. Immigrants are generally responsive to labor market conditions, and locate (in most cases) in areas with higher wages and lower rates of unemployment. The degree of this relationship differs across admission categories, however, with the most consistent 
relationship being found for male employment-based immigrants. This is perhaps not surprising; employment-based immigrants must enter the U.S. with a job. Given the cost of recruiting overseas, firms will likely only look for foreign workers if they are in markets in which native workers are scarce, or expensive, or both. In general, the results on the effect of labor market conditions on immigrant location choice would seem to strongly refute Bartel's (1989) claim that immigrants do not responds to labor market conditions. The results also cast doubt on the extensive literature that uses geographic variation in the concentration of immigrants to try to identify the relative demand curves of immigrants and natives. It is clear from these results that immigrants' locations cannot be treated as exogenous to labor demand.

Like previous researchers, I also find that foreign-born concentrations have a magnetic effect on newly-arrived immigrants. This magnetism is most strongly felt by relatives of legal permanent residents, although all groups are somewhat subject to it. Individuals in most admission categories are drawn to states in which individuals from their region-of-birth make up a higher percentage of the state population. The effects of the share of the foreign-born in the state population as well as the state's share of the total U.S. population of individuals from the immigrant's region-of-birth are much smaller for most admission groups in most years.

One surprising, but consistent, is the degree to which refugees' location choices seem to be influenced by labor market conditions; refugees are often relocated by government agencies or private charities, and I expected that refugees' responsiveness to labor market conditions would therefore be particularly low. One possibility is that the relocating agency is aware of which labor markets are best and then seeks refugees in those places.

Diversity immigrants and to some extent Western Hemisphere immigrants provide a quasi-natural experiment do not need to have any formal ties to the U.S. prior to arrival. Therefore the estimates of their responses to immigrant concentrations and labor market conditions most closely approximate what would happen if the U.S. shifted to a policy that required only that immigrants meet certain skill requirements but not have any link to someone already in the States. It is clear from these results that immigrants are naturally drawn to areas with good labor markets that bring the prospect of lower unemployment and higher wages, as well areas with foreign-born individuals from their home country.

How might these results inform immigration policy? If, as the results here and in Borjas (2001) suggest, immigrants are responsive to labor market conditions and increase labor market 
efficiency by being the margin on which labor markets equilibrate geographically, then it stands to reason that this "greasing the wheels" function of immigrants would be most enhanced by admitting more of the immigrants who are most responsive to labor market conditions. While the results suggest that all immigrants are, to some extent, sensitive to labor market conditions when deciding where to locate, employment visa immigrants and, surprisingly, refugees, are the most consistently sensitive to higher wages and lower rates of unemployment. Admitting more of these types of immigrants and, perhaps, fewer family-reunification immigrants, would increase labor market efficiency. 


\section{DAta ApPendix}

\section{Region of Birth Groups}

Region of birth groups are defined in both the Immigration and Naturalization Service data and in the various Censuses from the IPUMS. Codes for the different countries vary across different years of the INS data and between the INS data and the IPUMS. In addition, the names of some geographic areas have changed over time (e.g. the breakup of the Soviet Union). This list, therefore, is not exhaustive, but should be sufficient so that the reader knows which countries are included in which grouping.

Western Europe: Austria, Belgium, Denmark, Finland, France, Germany, Iceland, Ireland, Liechtenstein, Luxembourg, Monaco, Netherlands, Norway, Sweden, Switzerland, United Kingdom

Southern Europe: Gibraltar, Greece, Italy, Malta, Portugal, San Marino, Spain, Vatican City

Eastern Europe: Albania, Andorra, Bulgaria, Czechoslovakia, Estonia, Hungary, Latvia, Lithuania, Poland, Romania, Soviet Union, Yugoslavia

North America: Bermuda, Canada, Greenland, St. Pierre and Miquelon

Central America and Mexico: Belize, Costa Rica, El Salvador, Guatemala, Honduras, Mexico, Nicaragua, Panama

South America: Argentina, Bolivia, Brazil, Chile, Colombia, Ecuador, Falkland Islands, French Guyana, Guyana, Paraguay, Peru, Suriname, Uruguay, Venezuela

Caribbean: Anguilla, Antigua, Aruba, Bahamas, Barbados, British Virgin Islands, Cayman Islands, Cuba, Dominican Republic, Dominica, Grenada, Guadeloupe, Haiti, Jamaica, Martinique, Montserrat, Netherlands Antilles, St. Kits-Nevis, St. Lucia, St. Vincent and the Grenadines, Trinidad and Tobago, Turks and Caicos Islands

Africa: Algeria, Angola, Benin, Botswana, Burkina Faso, Burundi, Central African Republic, Cameroon, Cape Verde, Chad, Comoros, Congo, Djibouti, Egypt, Equitorial Guinea, Ethiopia, Gabon, Gambia, Ghana, Guinea, Guinea-Bissau, Ivory Coast, Kenya, Lesotho, Liberia, Libya, Madagascar, Malawi, Mali, Mauritania, Mauritius, Morocco, Mozambique, Namibia, Niger, Nigeria, Reunion, Rwanda, Sao Tome and Principe, Senegal, Seychelles, Sierra Leone, Somalia, South Africa, St. Helena, Sudan, Swaziland, Tanzania, Togo, Tunisia, Uganda, Western Sahara, Zaire, Zambia, Zimbabwe

Middle East: Bahrain, Cyprus, Iraq, Israel, Jordan, Kuwait, Lebanon, Oman, Qatar, Saudi Arabia, Syria, Turkey, United Arab Emirates, Yemen

Southwest Asia: Afghanistan, Bangladesh, Bhutan, India, Iran, Maldives, Nepal, Pakistan, Sri Lanka

Southeast Asia: Brunei, Burma, Cambodia, Indonesia, Laos, Malaysia, Philippines, Singapore, Thailand, Vietnam

East Asia: China, Hong Kong, Japan, Korea, Macau, Mongolia, Taiwan

Oceania: Australia, Christmas Island, Cocos Island, Cook Island, Fiji, French Polynesia, French Southern Antartic, Kiribati, Nauru, New Caledonia, New Zealand, Niue, Papua New Guinea, Pitcairn Island, Solomon Island ,Tonga, Tuvalu, Vanatu, Wallis and Futuna Islands, Westem Samoa 


\section{Distance}

Distance from country of birth to the state of intended residence is calculated as the straight line distance from the most populous city in the country of birth in 1991 to the geographic center of each state (taken from http://geography.about.com/library/weekly/aa120699a.htm). Distance, $d$, in 1,000s of miles is calculated following Sinnot (1984):

$$
d=\frac{2 \cdot 3956}{1000} \arcsin (\min (1, \sqrt{a}))
$$

where

$a=\sin \left(\frac{l a t_{2}-l a t_{1}}{2}\right)^{2}+\cos \left(l a t_{1}\right) \cdot \cos \left(l a t_{2}\right) \cdot \sin \left(\frac{l o n_{2}-l o n_{1}}{2}\right)^{2}$,

$l t_{2}$ and $l o n_{2}$ are the coordinates of the destination (in radians), $l a t_{1}$ and $l o n_{1}$ are the coordinates of the origin (in radians) and 3,956 is the diamteter of the earth in miles. This method treats the Earth as a perfect sphere, resulting in less measurement error than if the earth were treated as a flat plane.

\section{Occupation}

Occupation in the INS data is self-reported. For primary employment visa immigrants, the recorded occupation is the one that the immigrant will do in the U.S. All other immigrants are free to record whatever occupation they want. From the responses in the INS data it is impossible to tell whether recorded occupation is the one they will or want to do in the U.S. or one that they performed in their home country. The coding used by the INS was also, until recently, fairly idiosyncratic. The occupation groupings I use are the "least common denominator," i.e. the coding scheme in the INS data with the fewest categories, that was employed from 1983 to 1998.

\section{Skill Imputation}

Skill categories for individuals in the INS data were predicted on the basis of reported occupation, age, and marital status. I estimated an ordered logit using pooled data from the 1980 and 1990 IPUMS on foreign-born individuals aged 25 to 64, separately for men and women. The dependent variable has three categories: less than 12 years of school, 12 through 15 years of school, and 16 or more years of school. The method suggested by Jaeger (1997) was used to code the schooling categories. Results of the ordered logit regressions are presented in Appendix Table 1 . This method correctly predicts the within-sample educational category about $64 \%$ of the time in the IPUMS data. The predicted probabilities of being in each skill category for individual $i$ are then

$$
\begin{aligned}
& \hat{P}(S<12)_{i}=\left(1+\exp \left(X_{i} \hat{\beta}-\hat{\mu}_{1}\right)\right)^{-1} \\
& \hat{P}(S \geq 16)_{i}=\left(1+\exp \left(X_{i} \hat{\beta}-\hat{\mu}_{2}\right)\right)^{-1}-\left(1+\exp \left(X_{i} \hat{\beta}-\hat{\mu}_{1}\right)\right)^{-1}, \\
& \hat{P}(S \geq 16)_{i}=1-\hat{P}(S<12)_{i}-\hat{P}(S \geq 16)_{i}
\end{aligned}
$$


where $\hat{\mu}_{1}$ and $\hat{\mu}_{2}$ are the estimated cut points, $X_{i}$ is the vector of characteristics (age, age squared, occupational dummy variables, and a dummy variable for being married), and $\hat{\beta}$ is the vector of estimated coefficients.

\section{REFERENCES}

Bartel, A. (1989) "Where Do the New U.S. Immigrants Live?" Journal of Labor Economics, 7, 371-391.

Bauer, T., G. Epstein, and I. Gang (2002) "Herd Effects or Migration Networks? The Location Choice of Mexican Immigrants in the U.S.," Institute for the Study of Labor Discussion Paper 551, August.

Borjas, G. J. (1999) "The Economic Analysis of Immigration," in Handbook of Labor Economics, Volume 3A, ed. O. C. Ashenfelter and D. Card, 1697-1760. Amsterdam: North-Holland.

Borjas, G. J. (2001) "Does Immigration Grease the Wheels of the Labor Market," Brookings Papers on Economic Activity, 1:2001, 1-51.

Cragg, M. and M. Kahn (1997) "New Estimates of Climate Demand: Evidence from Migration," Journal of Urban Economics, 42, 261-284.

Dunlevey, J. A. (1991) "On the Settlement Patterns of Recent Caribbean and Latin Immigrants to the U.S.," Growth and Change, 22, 54-67.

Jaeger, D. A. (1997) "Reconciling Educational Attainment Questions in the CPS and the Census," Monthly Labor Review, 1218, 36-40.

Jaeger, D. A. (2000) "Local Labor Markets, Admission Categories, and Immigrant Location Choice," Hunter College and Graduate Center, City University of New York, unpublished mimeo.

McFadden, D. (1984) "Econometric Analysis of Qualitative Choice Models," in Handbook of Econometrics, Volume 2, ed. Z. Griliches and M. D. Intriligator, 1396-1456. Amsterdam: North-Holland.

Ruggles, S., M. Sobek, T. Alexander, C. A. Fitch, R. Goeken, P. K. Hall, M. King, and C. Ronnander (2004) Integrated Public Use Microdata Series: Version 3.0 [Machinereadable database], Minneapolis, MN: Minnesota Population Center [producer and distributor]. URL: http://www.ipums.org.

Sinnot, R. W. (1984) "Virtues of the Haversine," Sky and Telescope, 68(2), 159.

United States Census Bureau (2006) Statistical Abstract of the United States, Washington, D.C.: Government Printing Office. URL: http://www.census.gov/statab/www. 
United States Department of Justice (2000) Immigrants Admitted to the United States [documentation to machine-readable database], Washington, D.C.: Immigration and Naturalization Service [producer]. Inter-University Consortium for Political and Social Research version, 2002, Ann Arbor, MI. [distributor]. URL: http://webapp.icpsr.umich.edu/cocoon/ICPSR-STUDY/03486.xml. 
Figure 1

Number of Immigrants Admitted to the U.S.

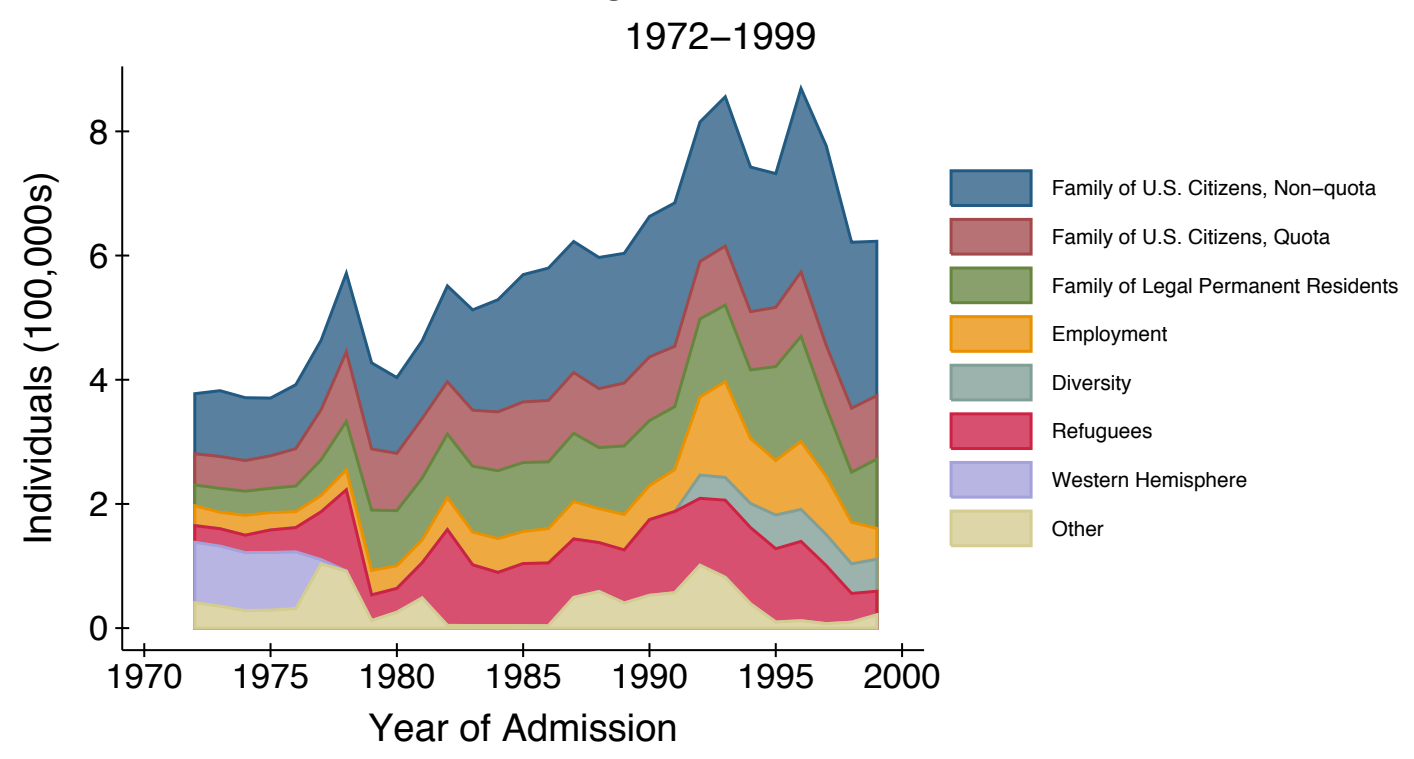

Source: Author's tabulations of Immigration and Naturalization Service data Note: 48 contiguous states.

Figure 2

Share of Admission Categories of Immigrants Admitted to the U.S.

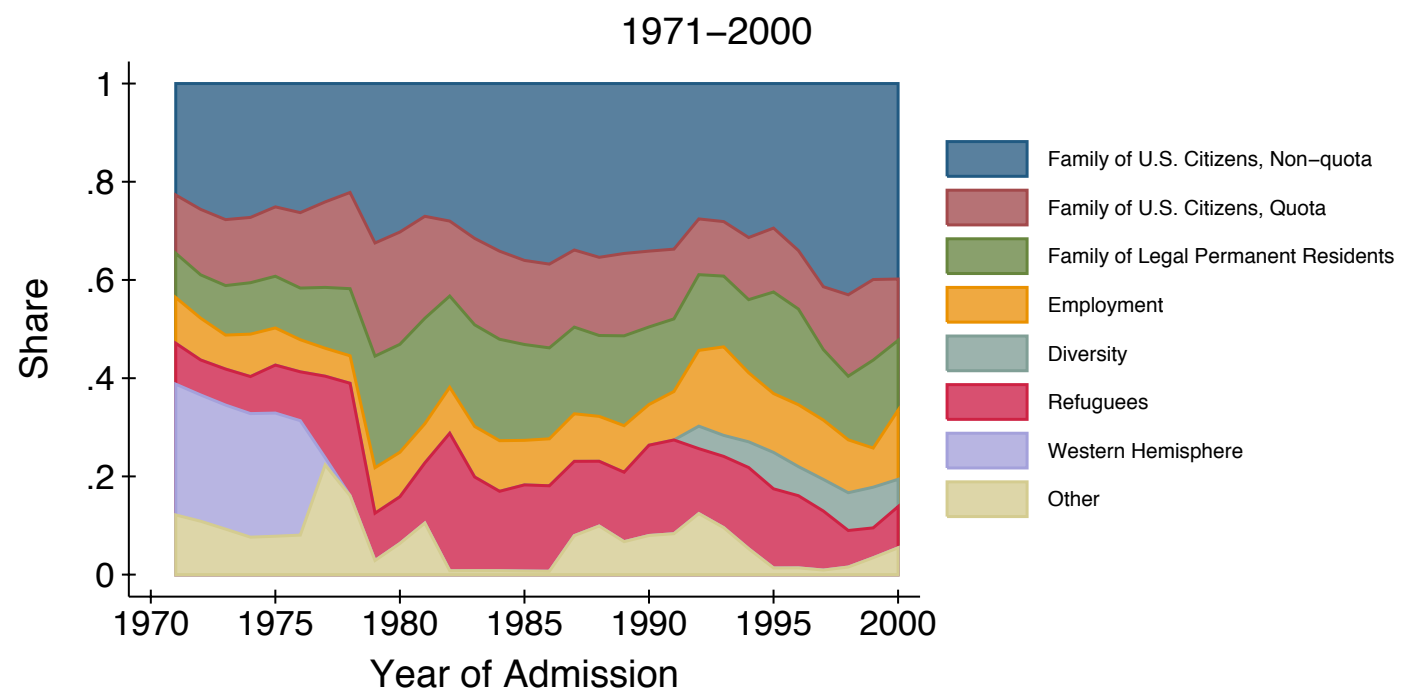

Source: Author's tabulations of Immigration and Naturalization Service data. Note: 48 contiguous states. 
Figure 3

Share by Country of Birth of Relatives of U.S. Citizens, Non-Quota

1971-2000

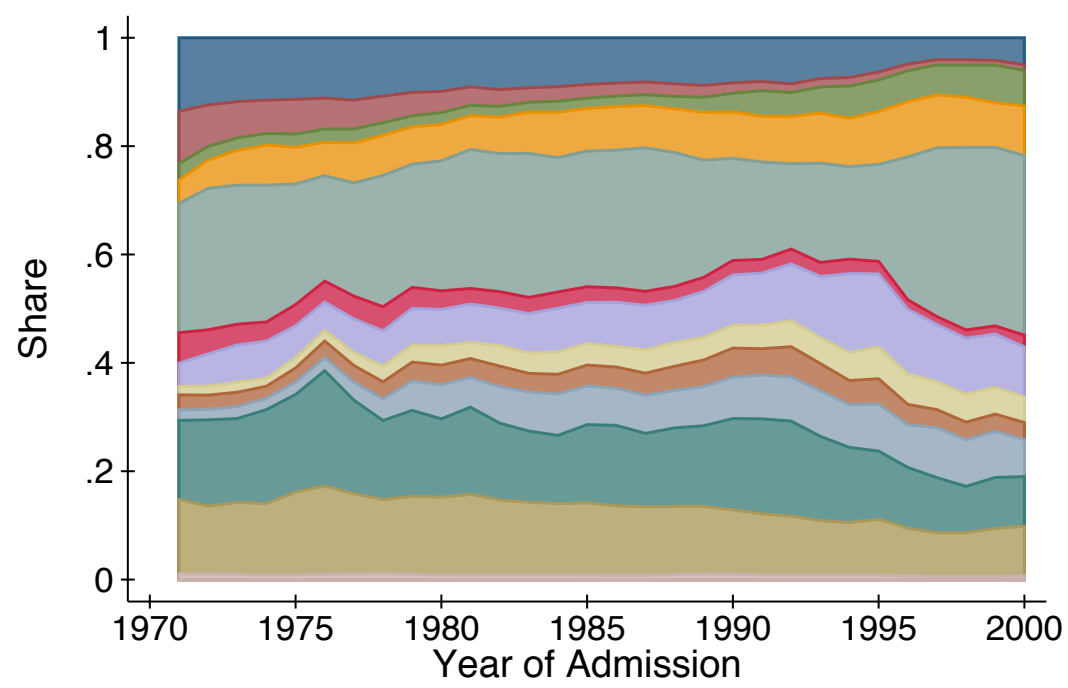

Western Europe

Southern Europe

Eastern Europe

North America

Mexico \& Cent. America

South America

Caribbean

Africa

Middle East

Southwest Asia

Southeast Asia

East Asia

Oceania

Source: Author's tabulations of Immigration and Naturalization Service data. Note: 48 contiguous states.

Figure 4

Share by Country of Birth of Relatives of U.S. Citizens, Quota

1971-2000

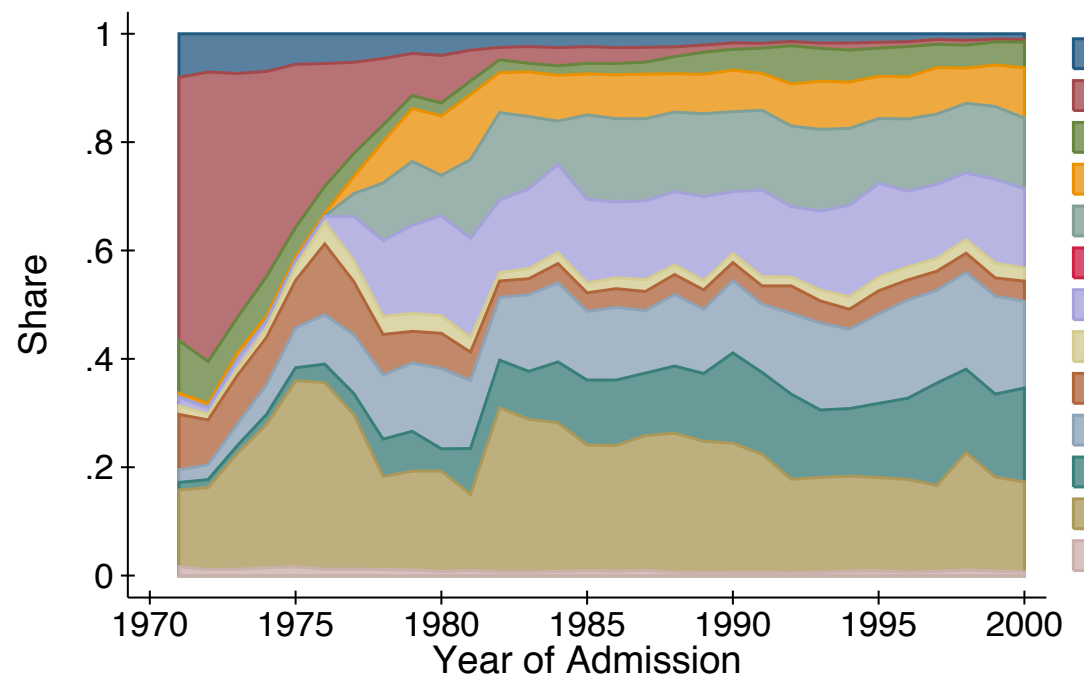

Western Europe

Southern Europe

Eastern Europe

North America

Mexico \& Cent. America

Caribbean

South America

Africa

Middle East

Southwest Asia

Southeast Asia

East Asia

Oceania

Source: Author's tabulations of Immigration and Naturalization Service data. Note: 48 contiguous states. 
Figure 5

Share by Country of Birth of Relatives of Legal Permanent Residents

1971-2000

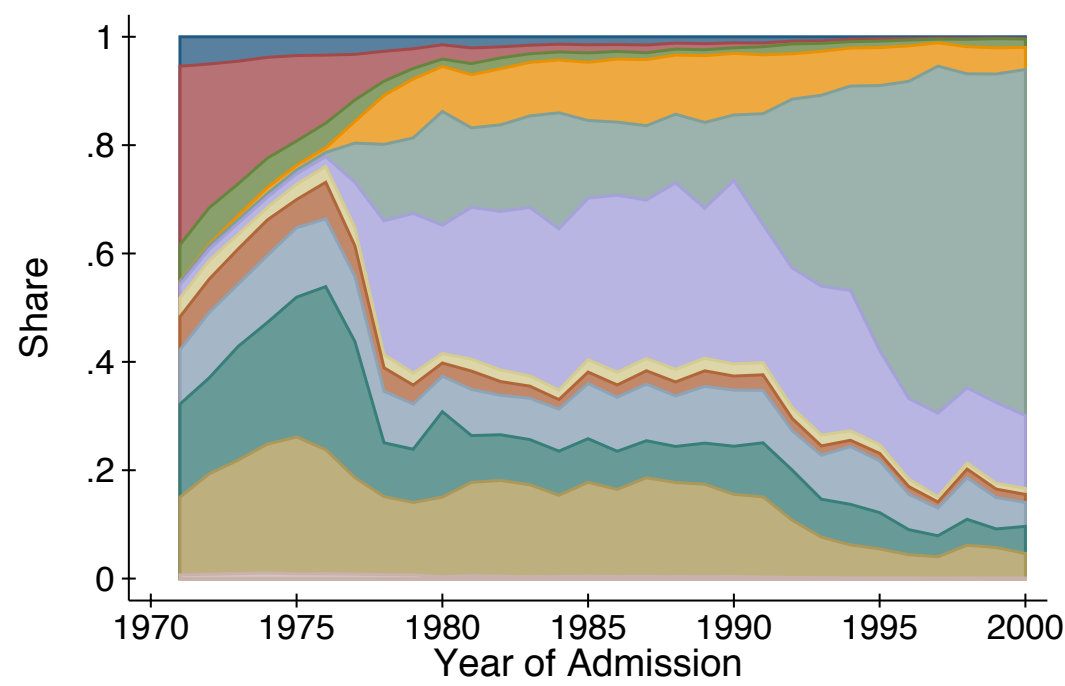

Western Europe

Southern Europe

Eastern Europe

North America

Mexico \& Cent. America

Caribbean

South America

Africa

Middle East

Southwest Asia

Southeast Asia

East Asia

Oceania

Source: Author's tabulations of Immigration and Naturalization Service data. Note: 48 contiguous states.

Figure 6

Share by Country of Birth of Employment Immigrants

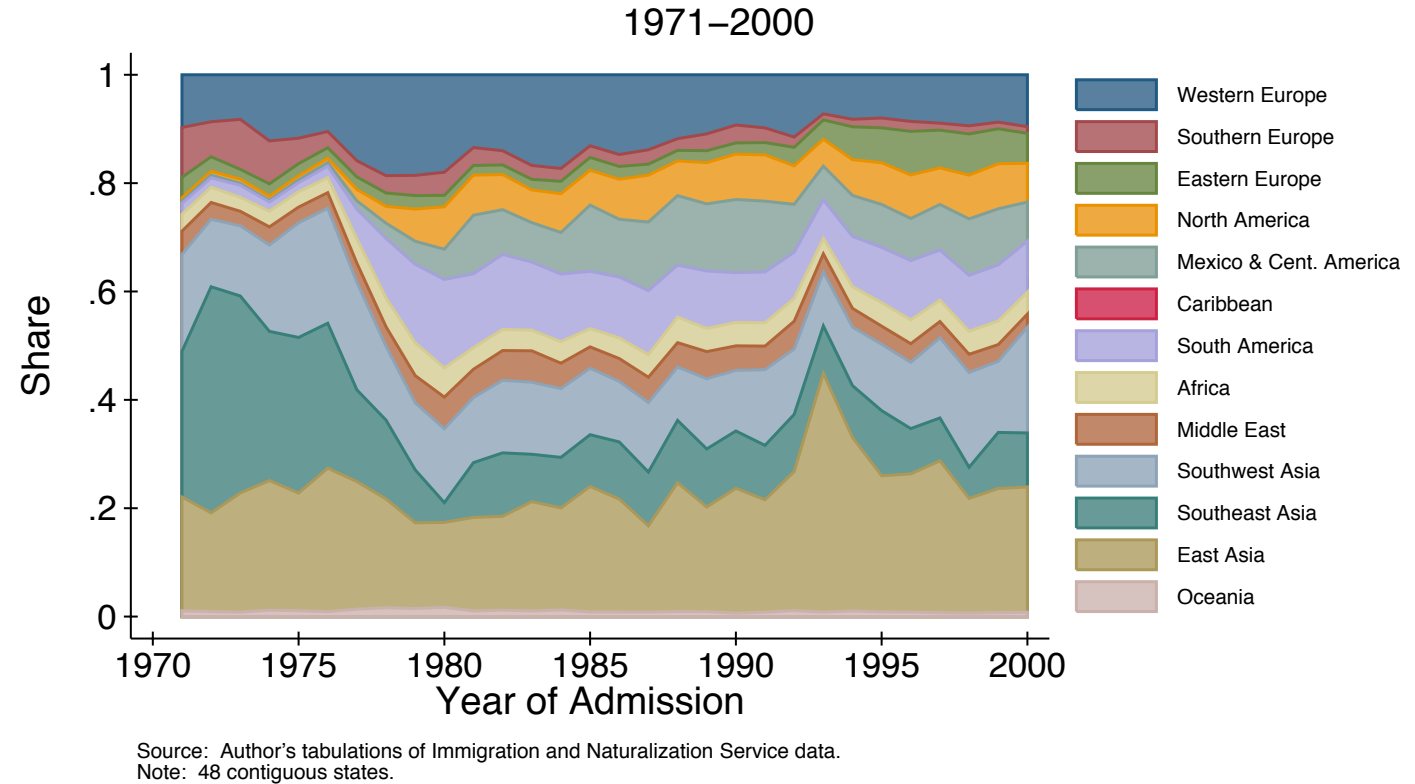


Figure 7

Share by Country of Birth of Western Hemisphere and Diversity Immigrants

1971-2000

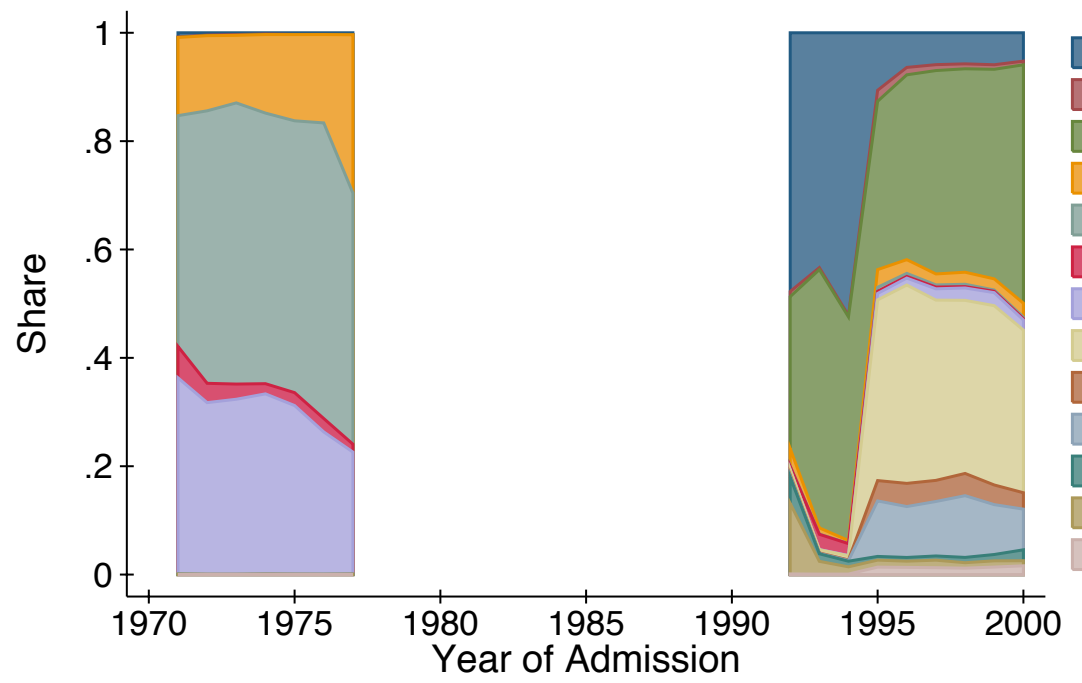

Western Europe

Southern Europe

Eastern Europe

North America

Mexico \& Cent. America

South America

Caribbean

Africa

Middle East

Southwest Asia

Southeast Asia

East Asia

Oceania

Source: Author's tabulations of Immigration and Naturalization Service data. Note: 48 contiguous states.

Figure 8

Share by Country of Birth of Refugees

1971-2000

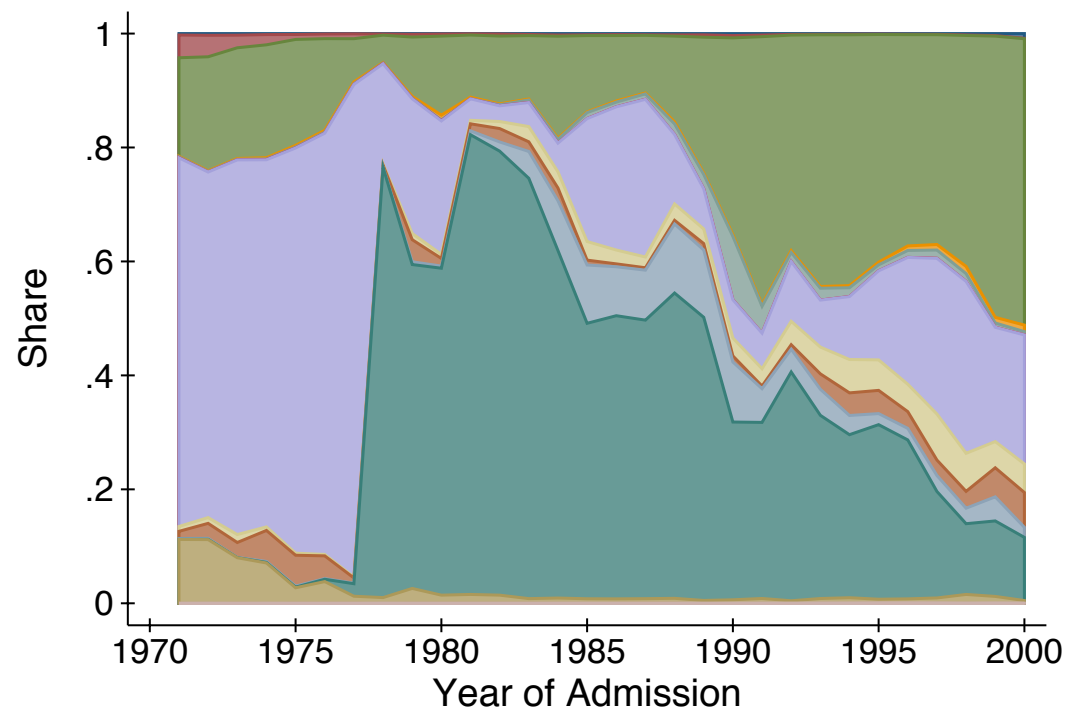

Western Europe

Southern Europe

Eastern Europe

North America

Mexico \& Cent. America

South America

Caribbean

Africa

Middle East

Southwest Asia

Southeast Asia

East Asia

Oceania

Source: Author's tabulations of Immigration and Naturalization Service data. Note: 48 contiguous states. 
Figure 9

Geographic Concentration of

Stock of Foreign-Born and Natives, Flow of Immigrants

1970-2000

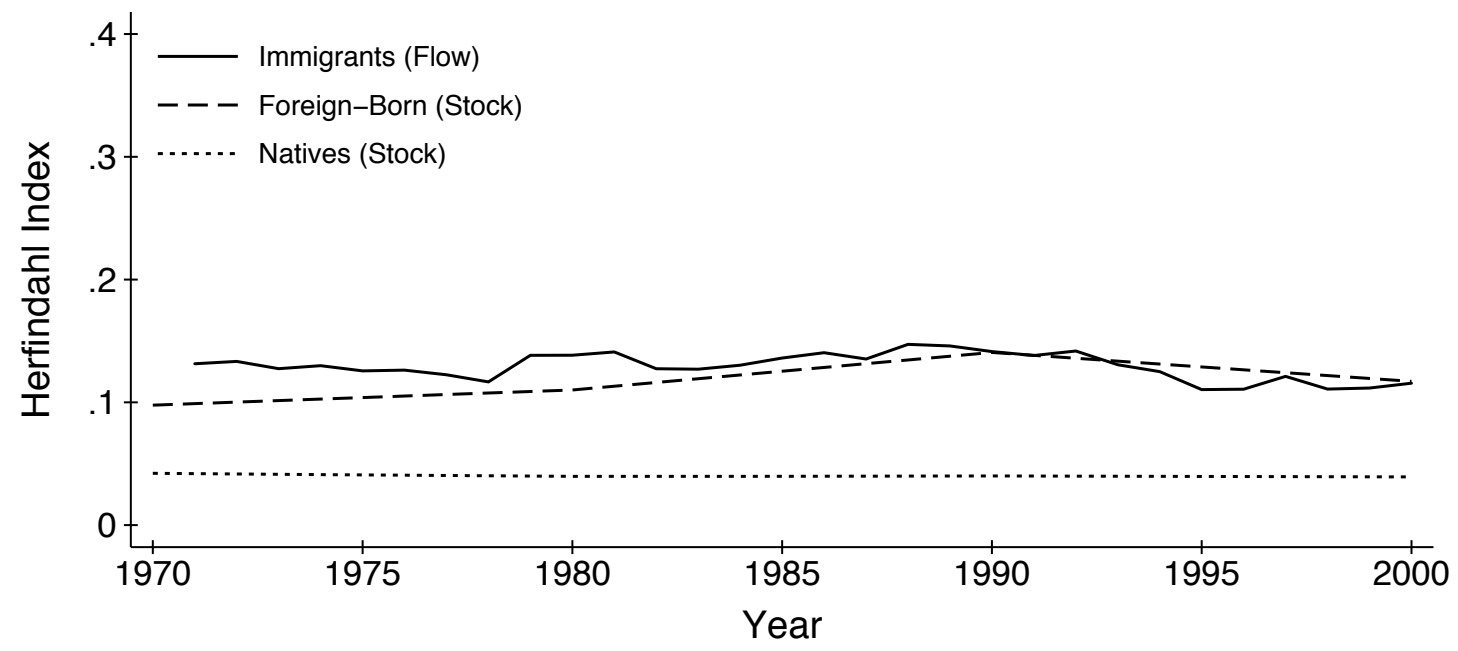

Source: Author's tabulations of Integrated Public Use Microsample Census and Immigration and Naturalization Service data. Note: 48 contiguous states.

Figure 10

Geographic Concentration of

Family Reunification Immigrants

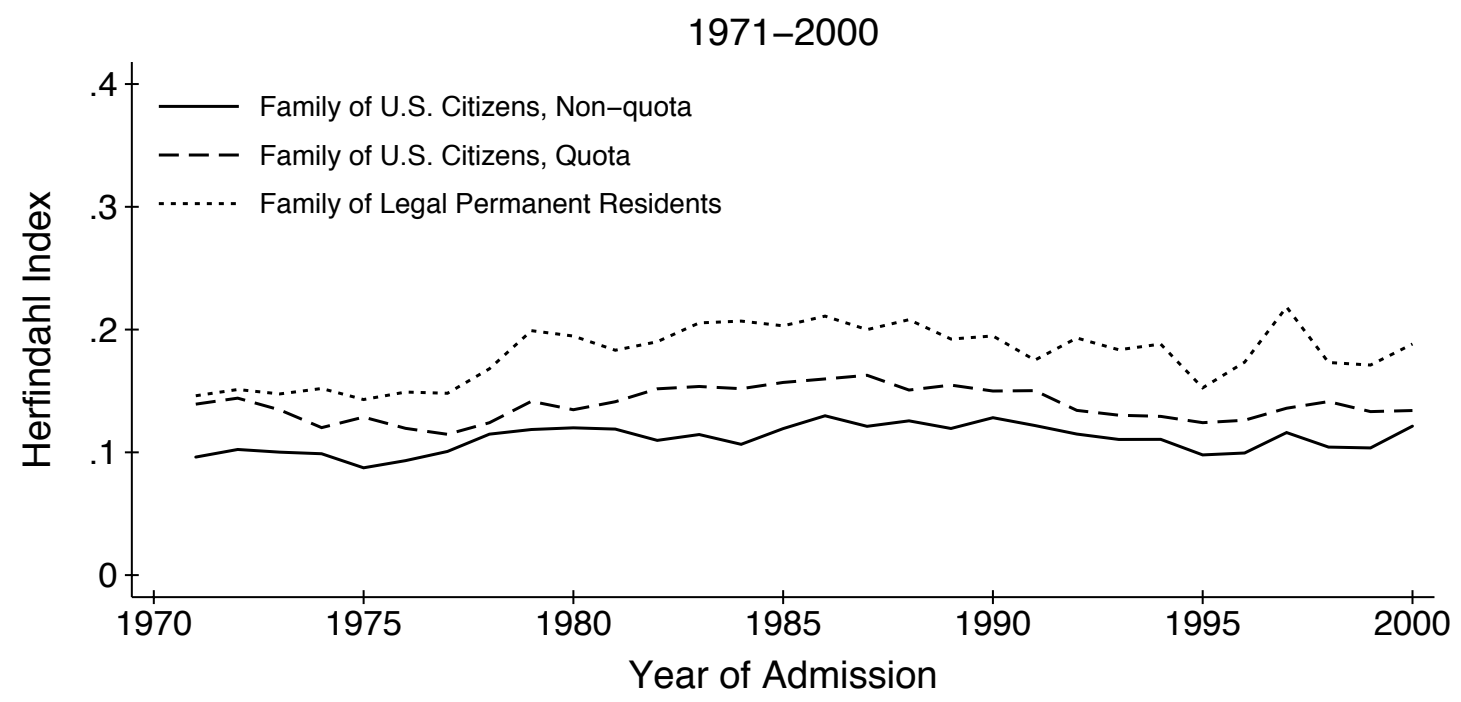

Source: Author's tabulations of Immigration and Naturalization Service data. Note: 48 contiguous states. 
Figure 11

Geographic Concentration of

Employment, Refugee, Diversity, and Western-Hemisphere

1971-2000

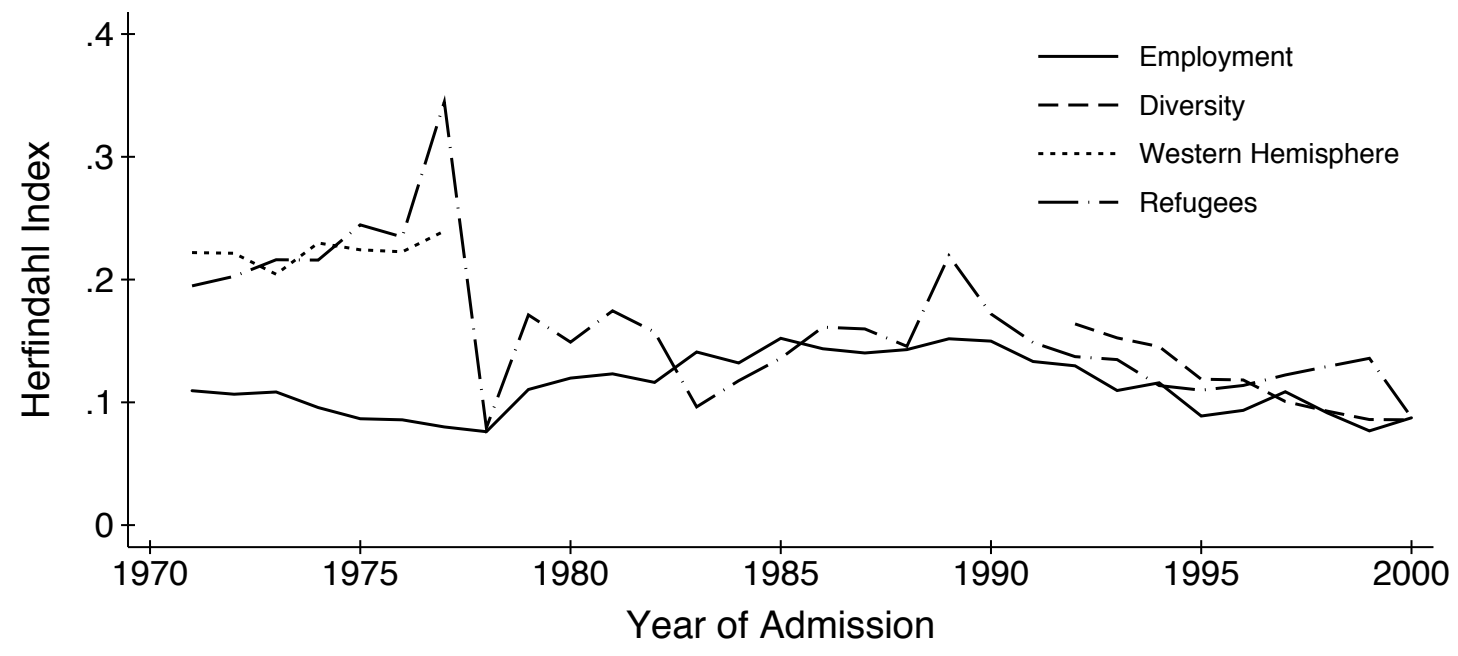

Source: Author's tabulations of Immigration and Naturalization Service data. Note: 48 contiguous states. 

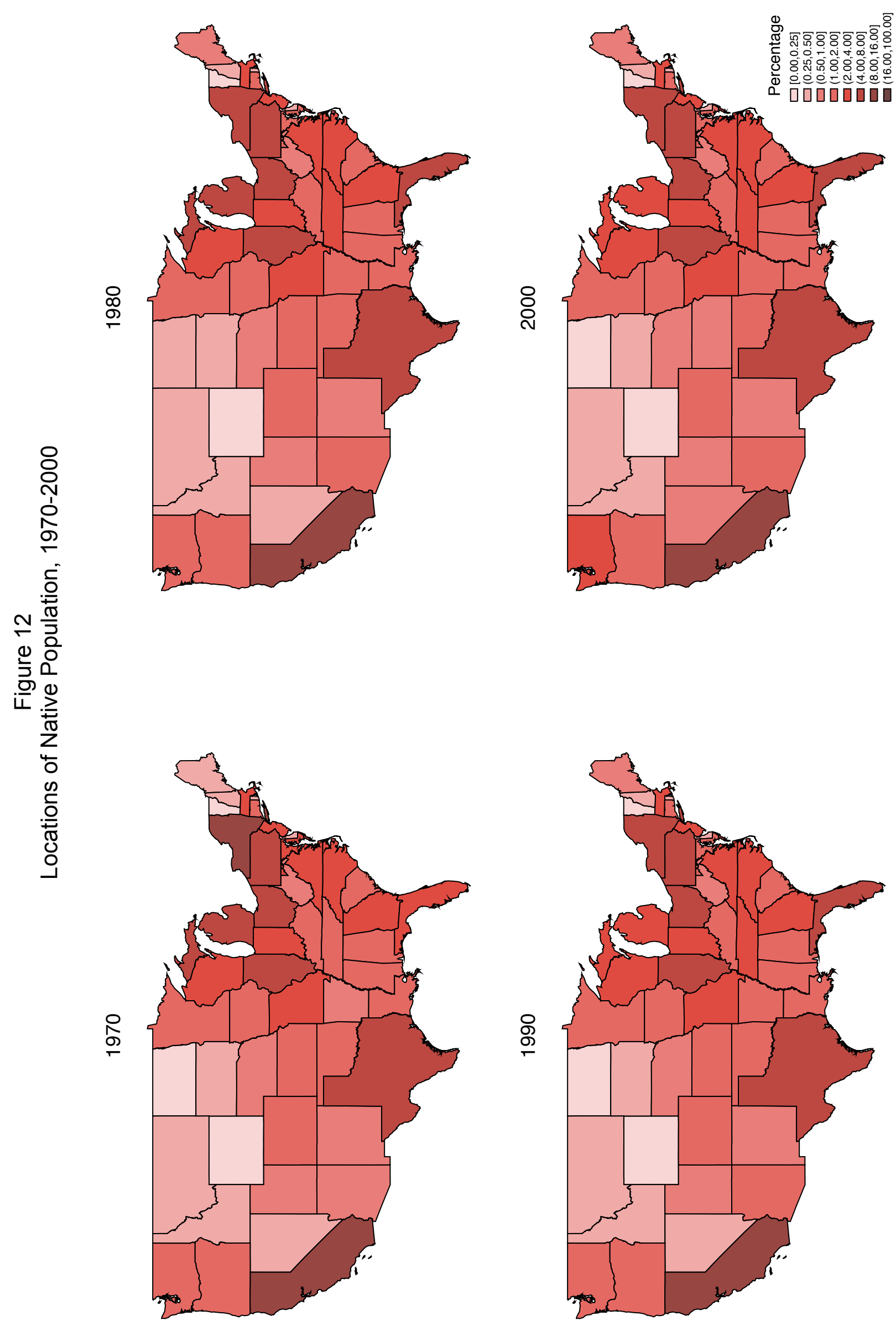

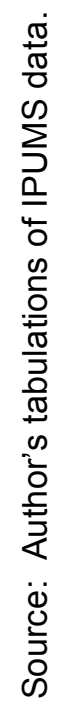



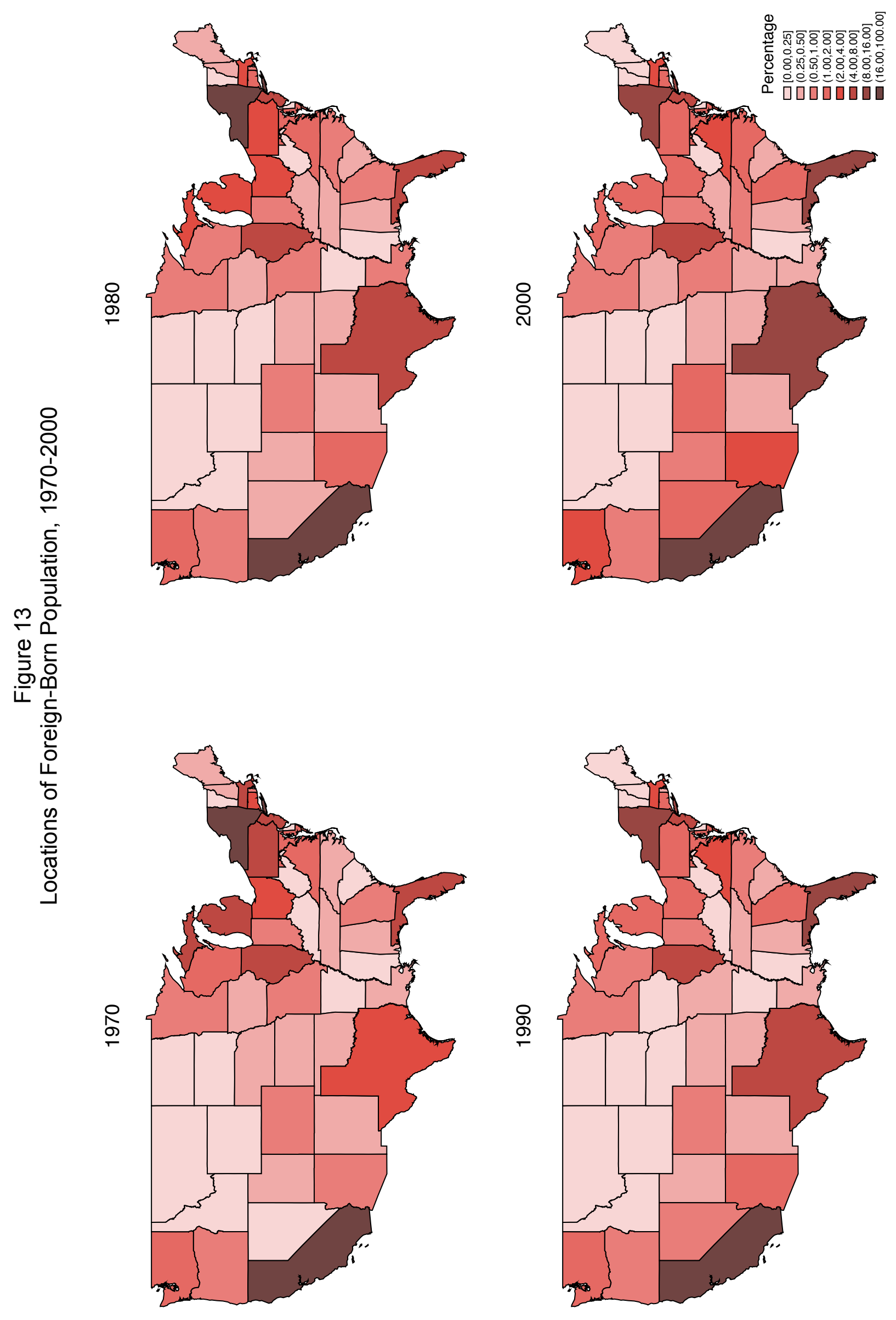

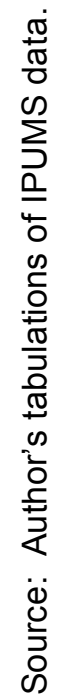


Figure 14

Locations of Relatives of U.S. Citizens, Non-Quota

1971-1980

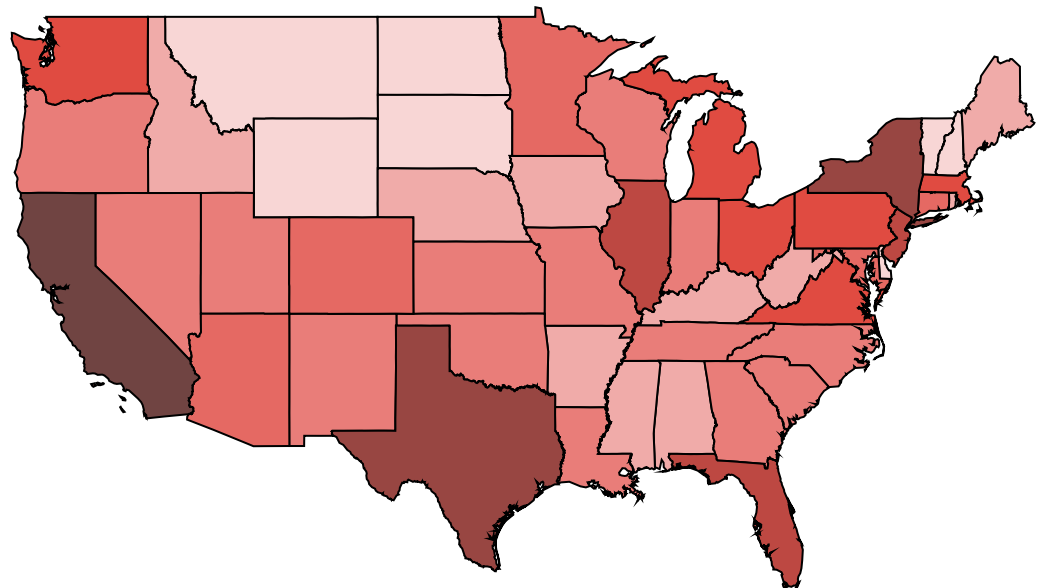

$$
1981-1990
$$

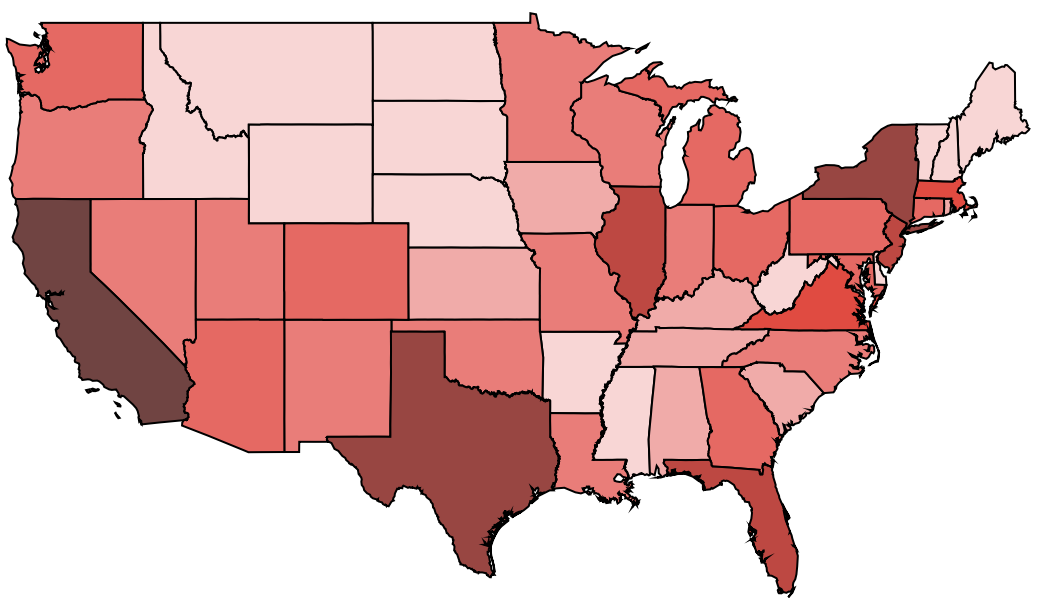

$1991-2000$

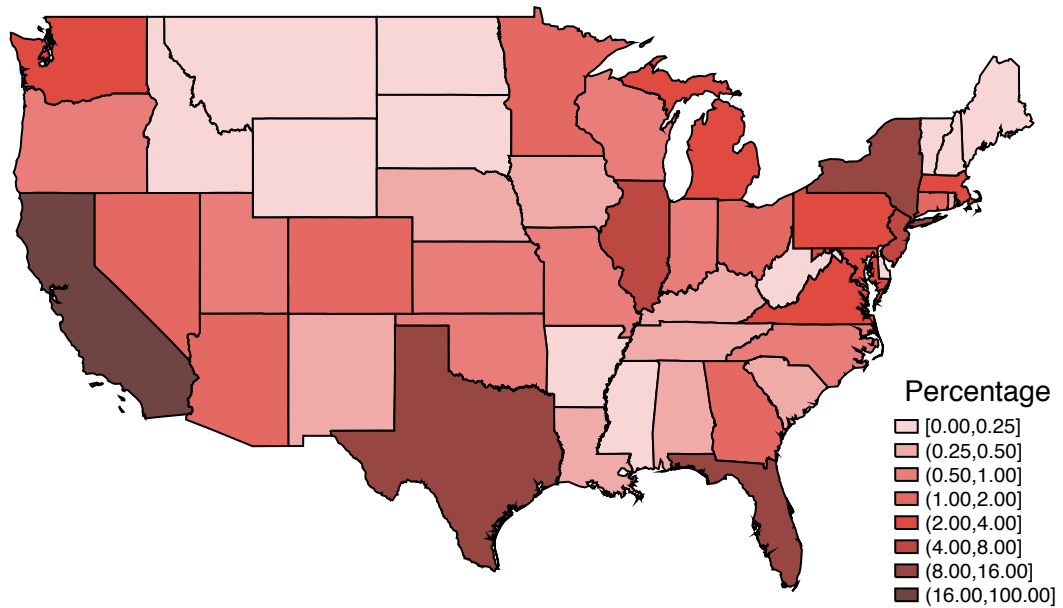


Figure 15

Locations of Relatives of U.S. Citizens, Quota

1971-1980

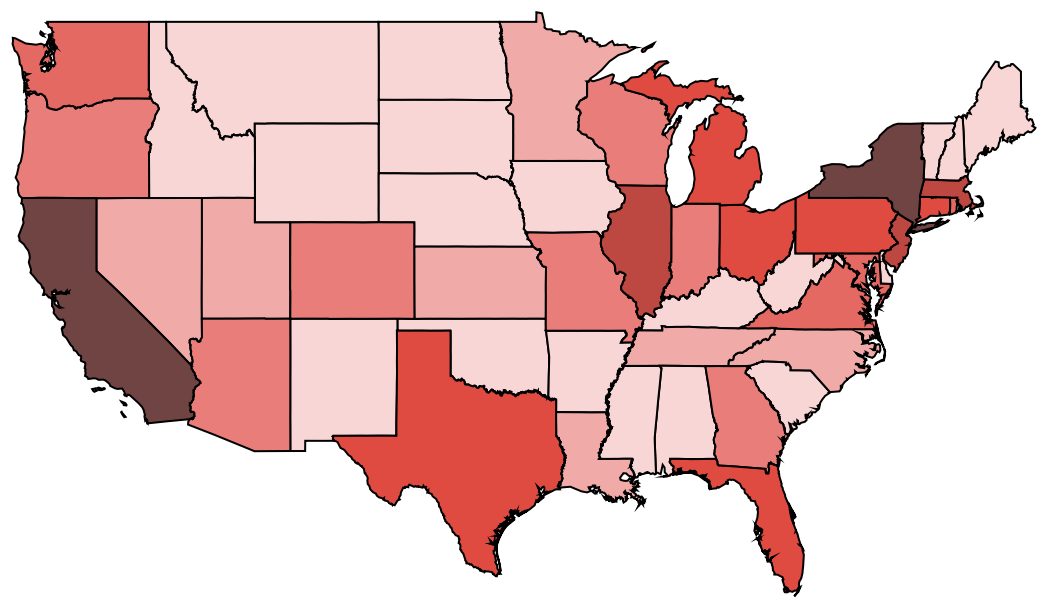

$1981-1990$

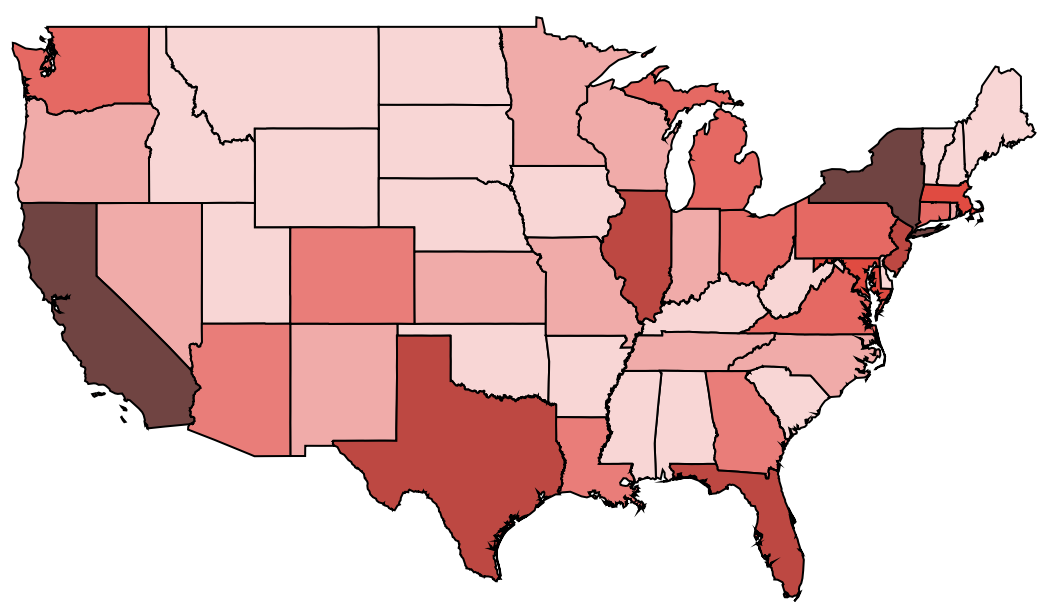

$1991-2000$

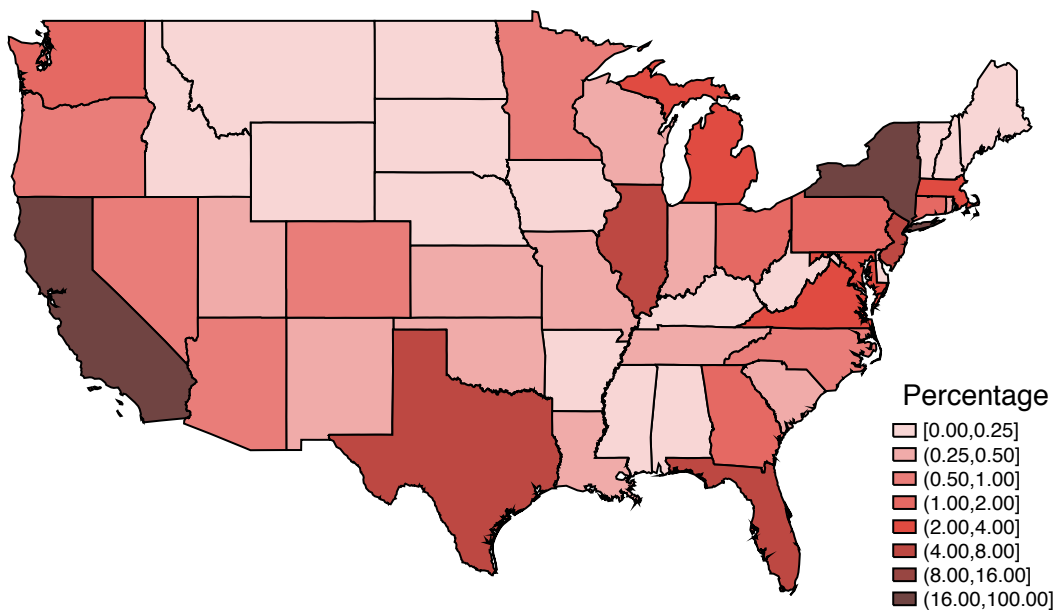


Figure 16

Locations of Relatives of Legalized Permanent Residents 1971-1980
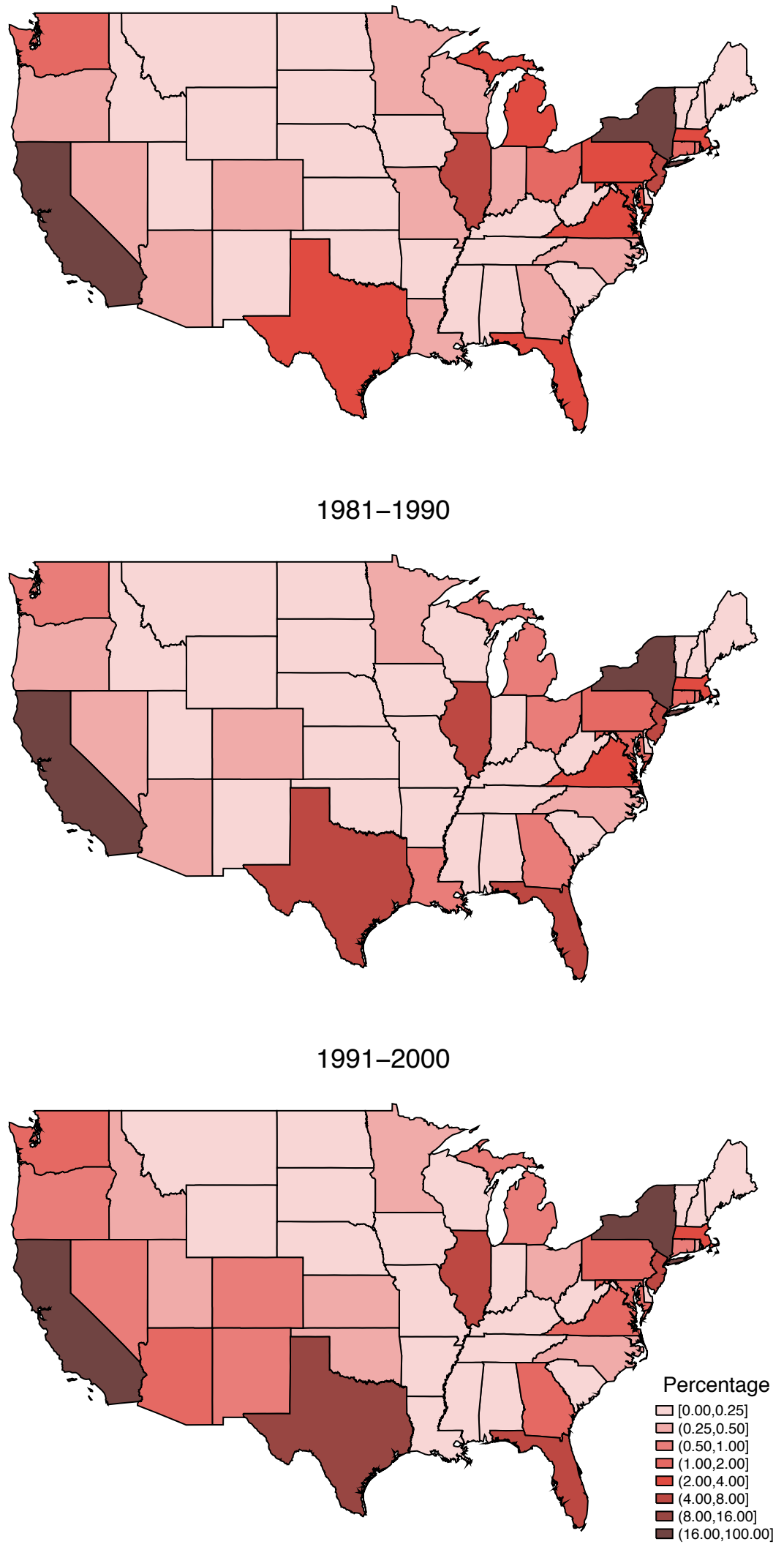
Figure 17

Locations of Employment Visa Immigrants

$1971-1980$

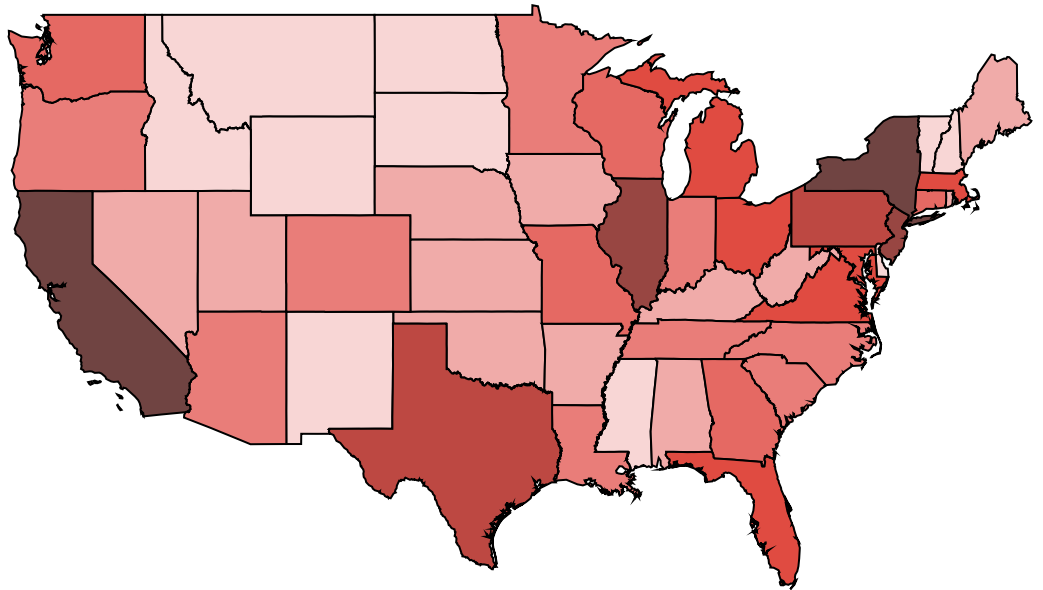

$1981-1990$

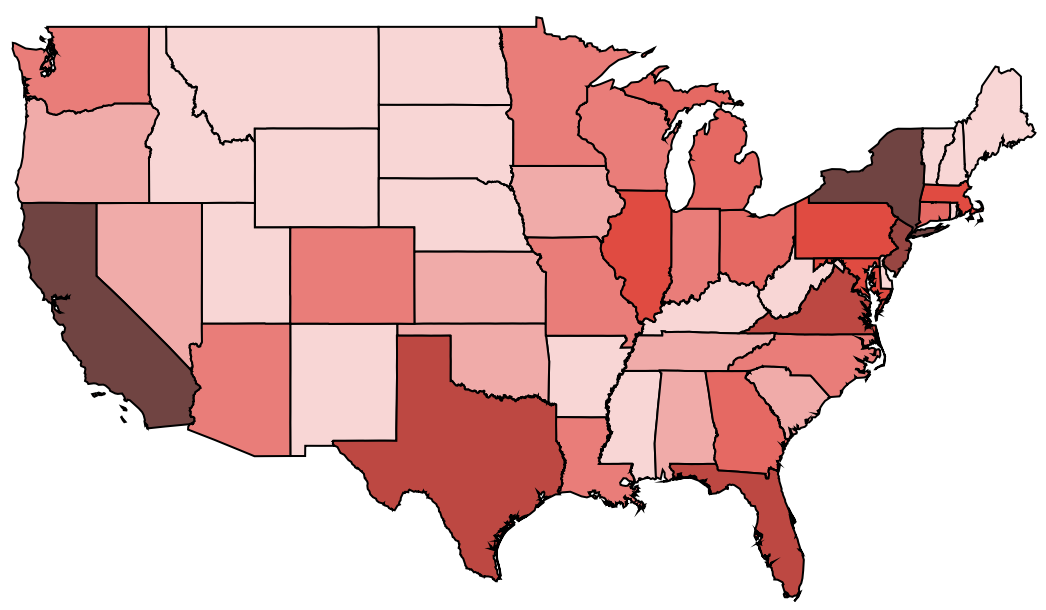

$1991-2000$

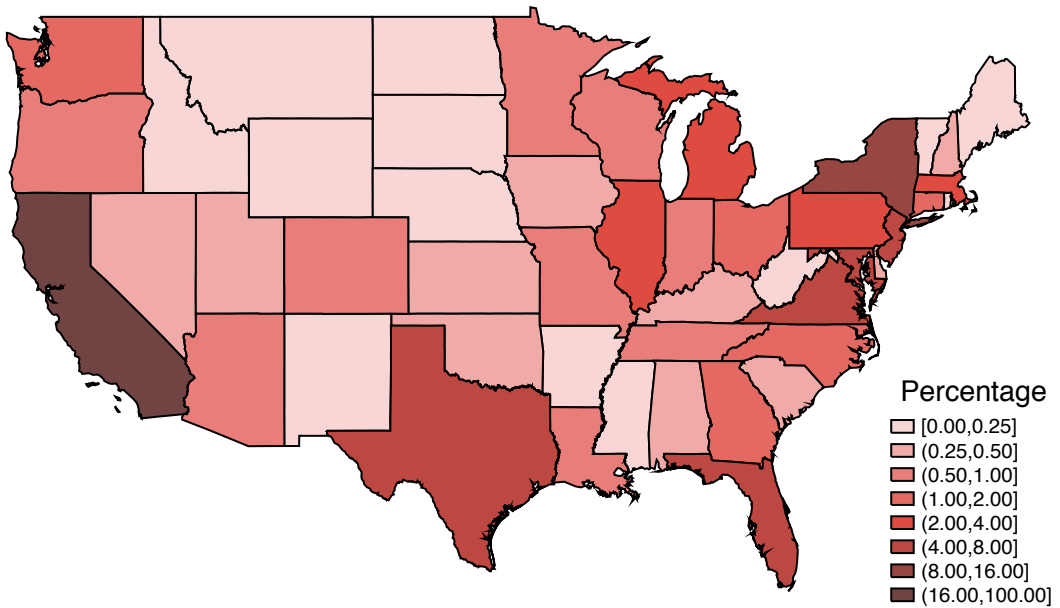


Figure 18

Locations of Western-Hemisphere and Diversity Immigrants

Western Hemisphere 1971-1977

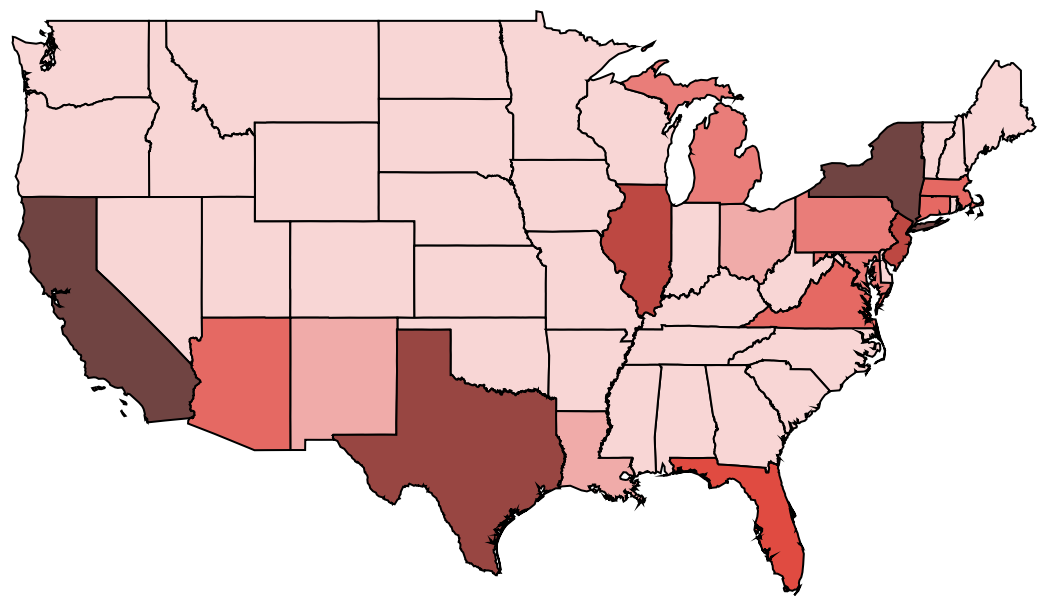

Diversity 1992-2000

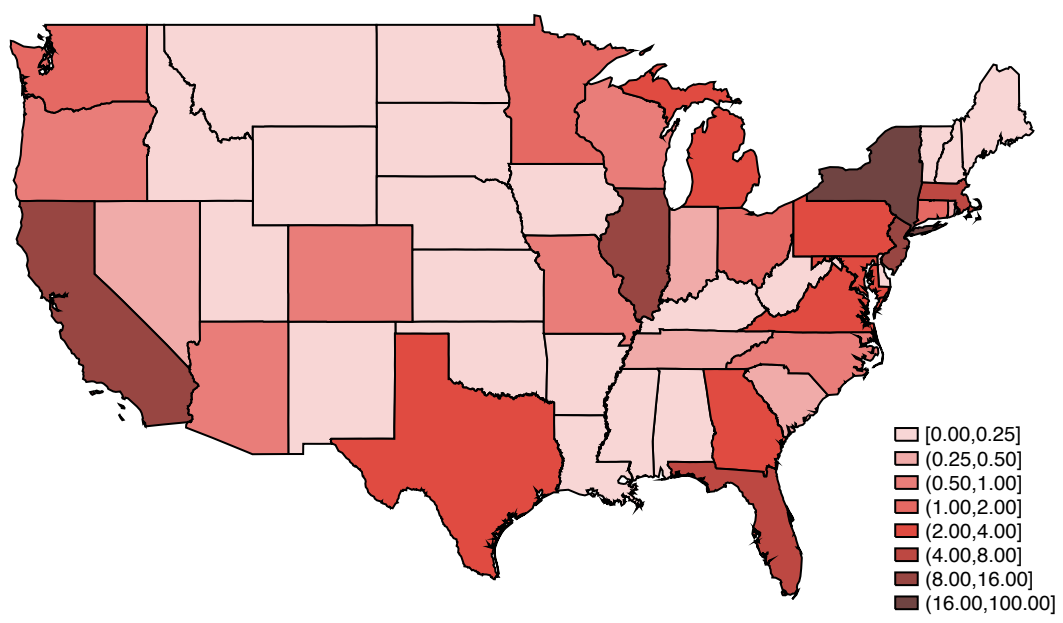


Figure 19

Locations of Refugees

$1971-1980$
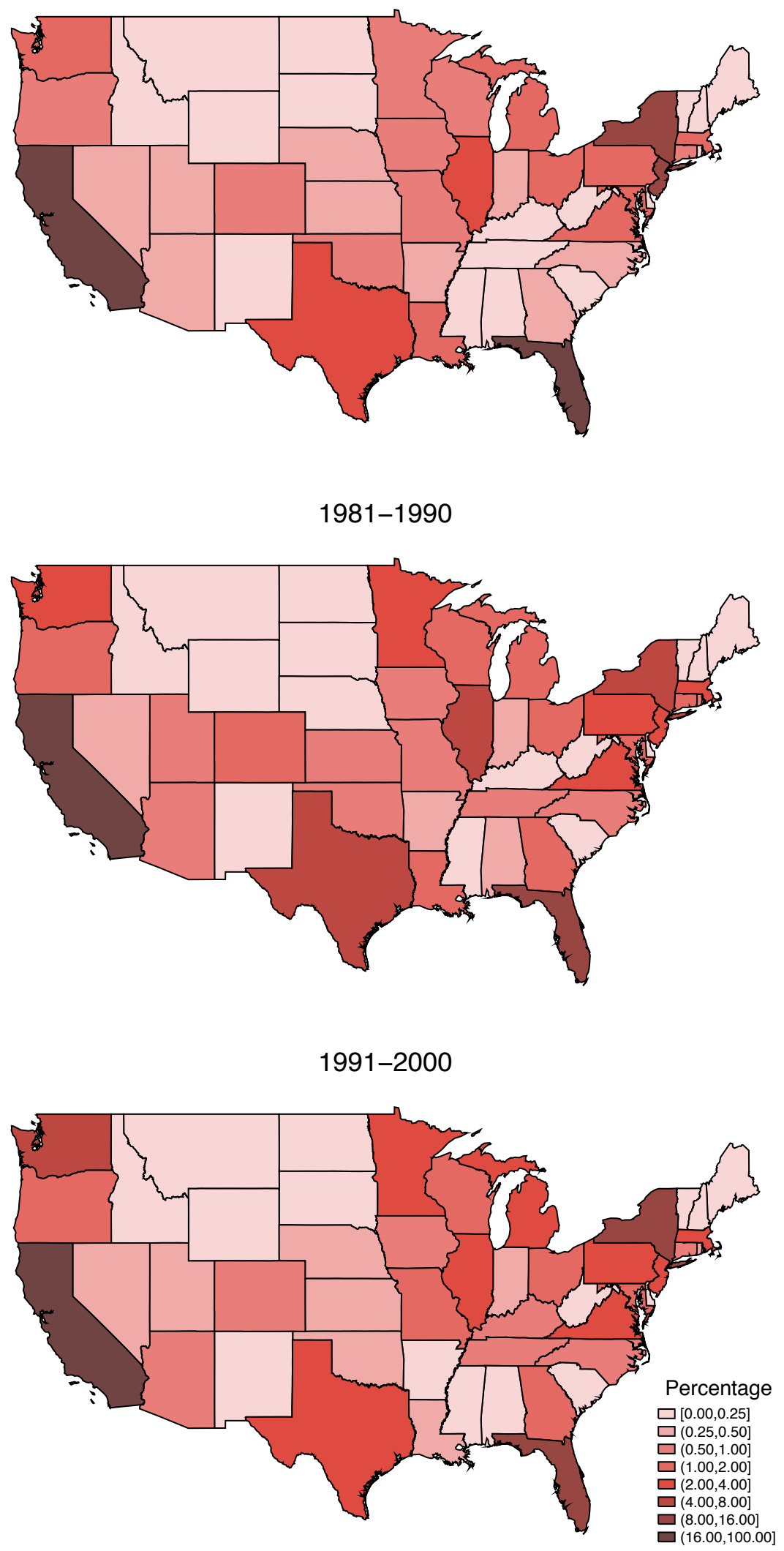
Figure 20

Share of Skill Group

Relatives of U.S. Citizens, Non-Quota

1971-2000

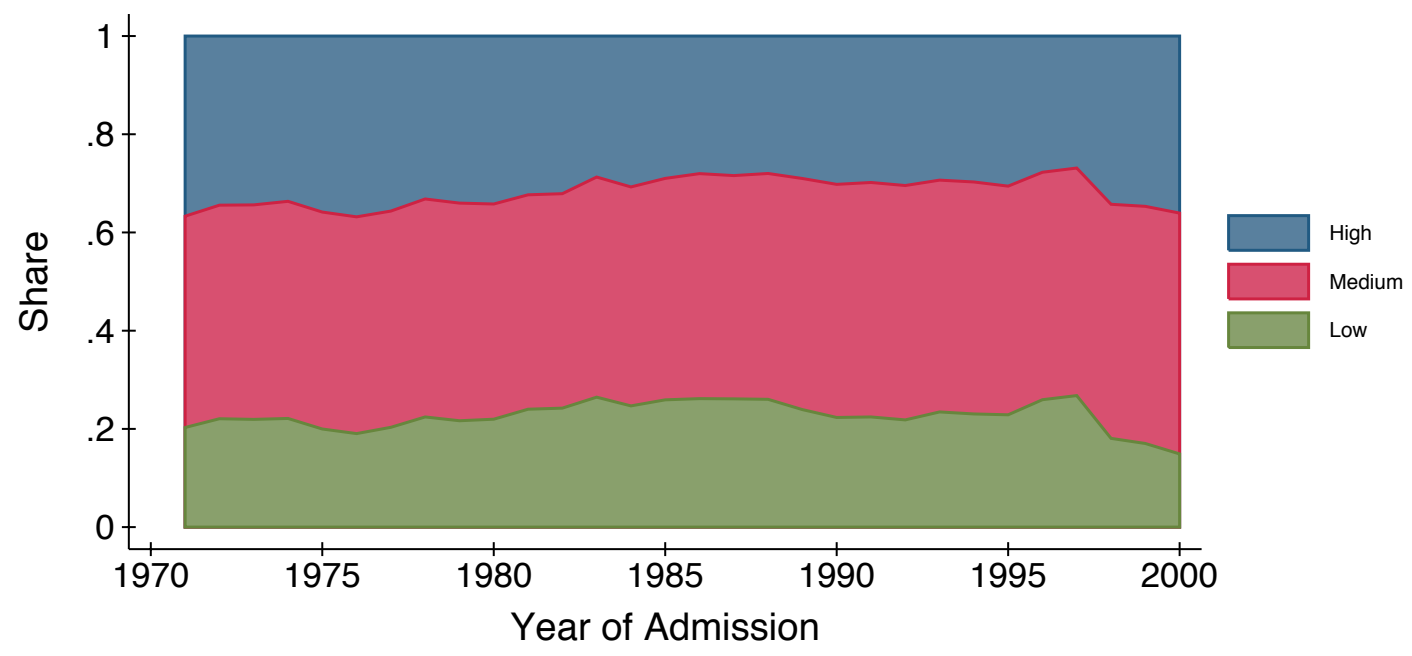

Source: Author's tabulations of Immigration and Naturalization Service data. Note: 48 contiguous states.

Figure 21

Share by Skill Group of

Relatives of U.S. Citizens, Quota

1971-2000

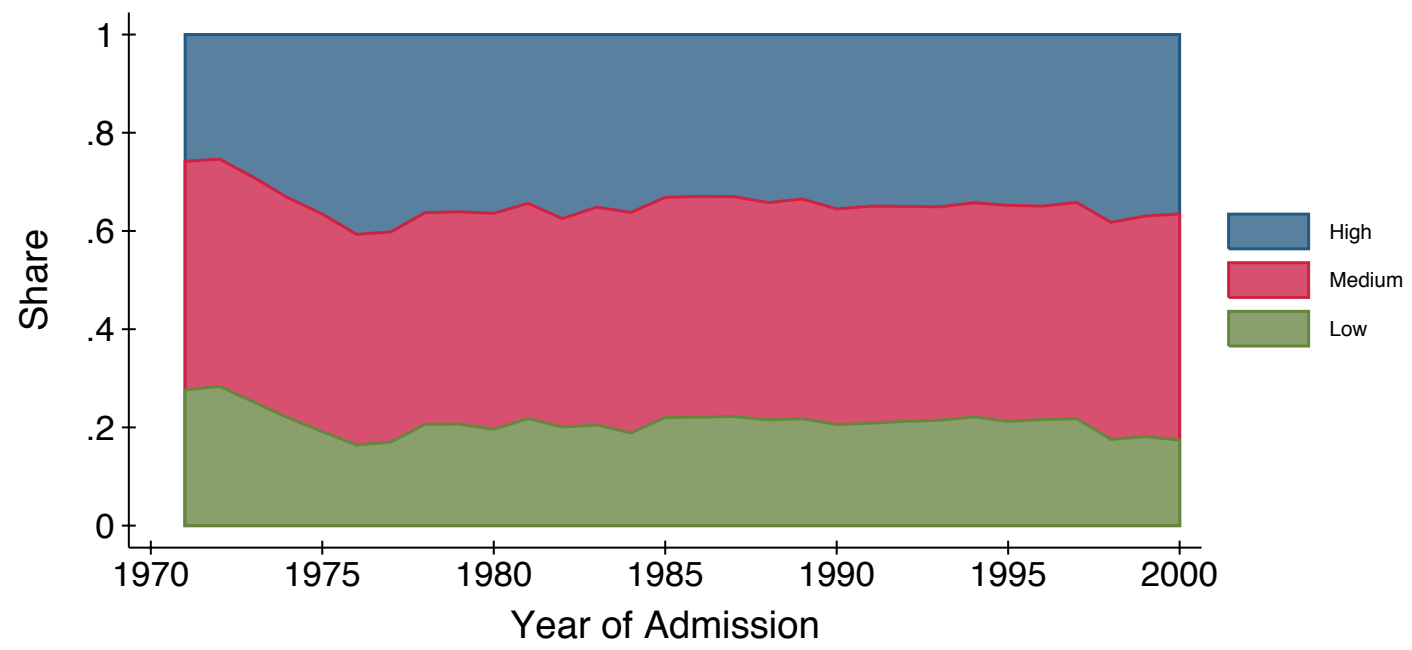

Source: Author's tabulations of Immigration and Naturalization Service data. Note: 48 contiguous states. 
Figure 22

Share by Skill Group of

Relatives of Legal Permanent Relatives

1971-2000

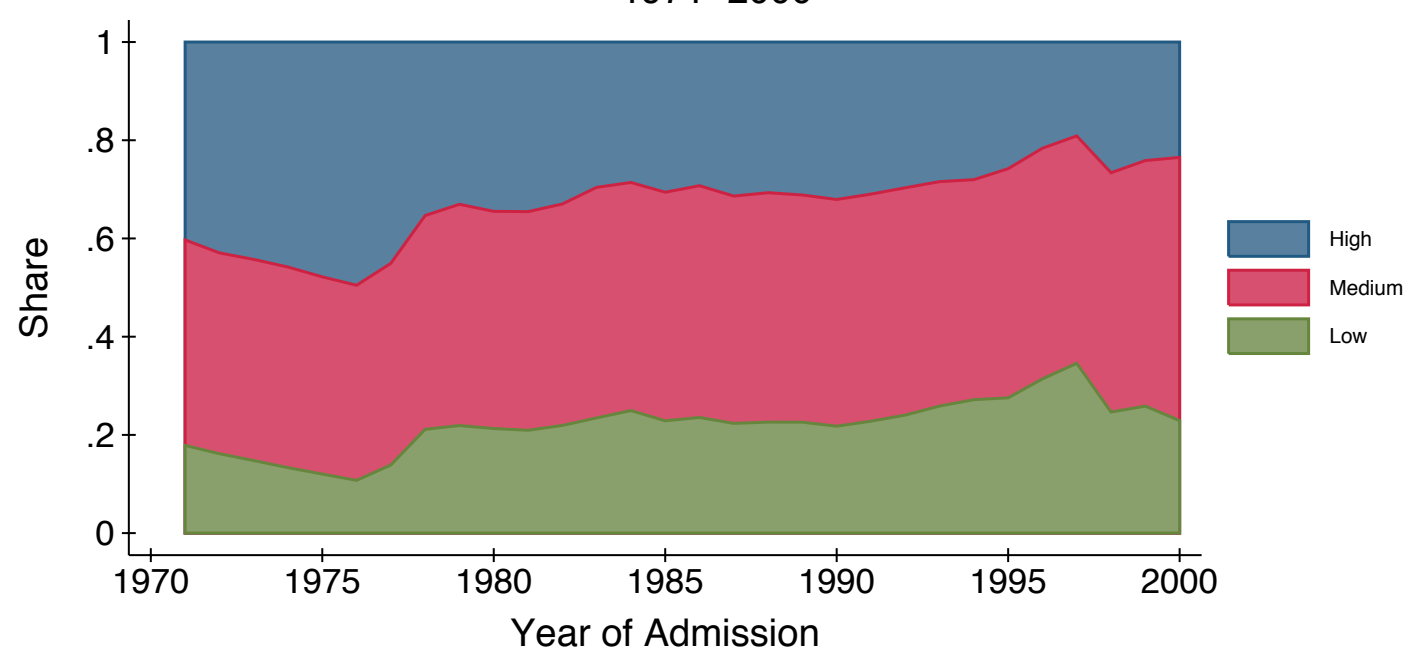

Source: Author's tabulations of Immigration and Naturalization Service data. Note: 48 contiguous states.

Figure 23

Share by Skill Group of

Employment Immigrants

1971-2000

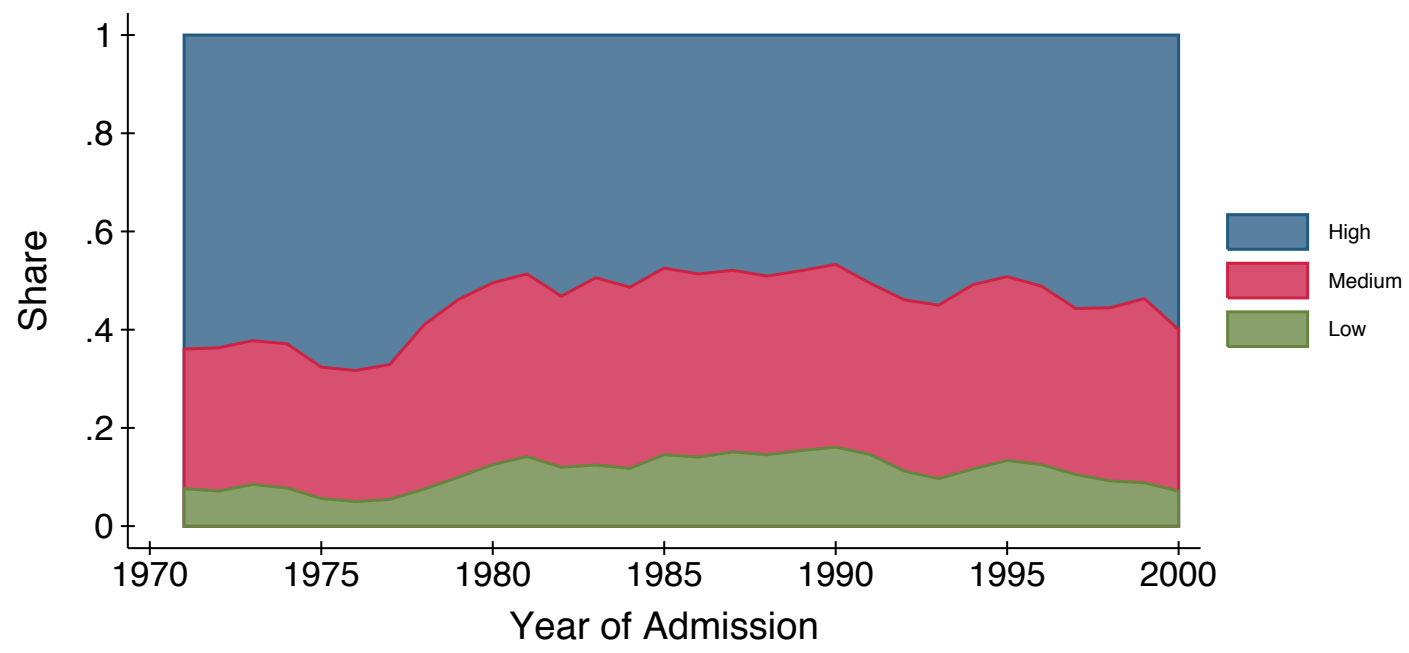

Source: Author's tabulations of Immigration and Naturalization Service data. Note: 48 contiguous states. 
Figure 24

Share by Skill Group of

Western Hemisphere and Diversity Immigrants

1992-2000

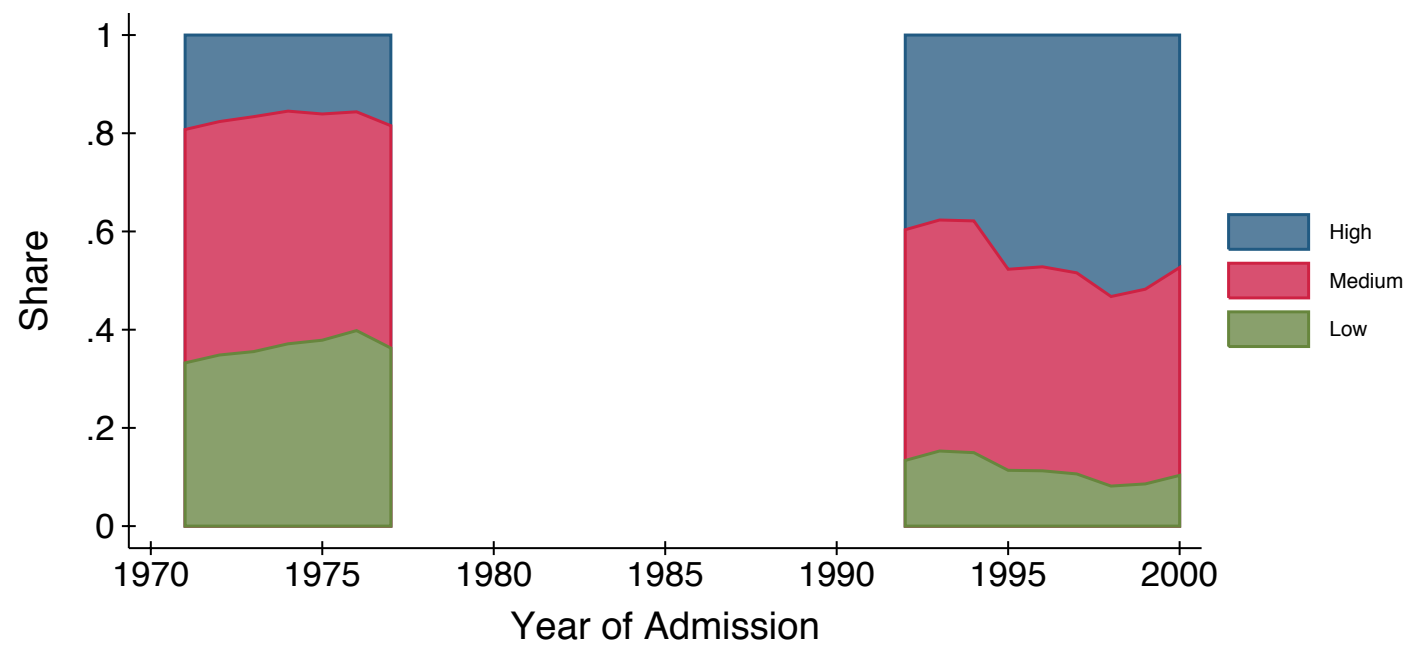

Source: Author's tabulations of Immigration and Naturalization Service data. Note: 48 contiguous states.

Figure 25

Share by Skill Group of Refugees

1971-2000

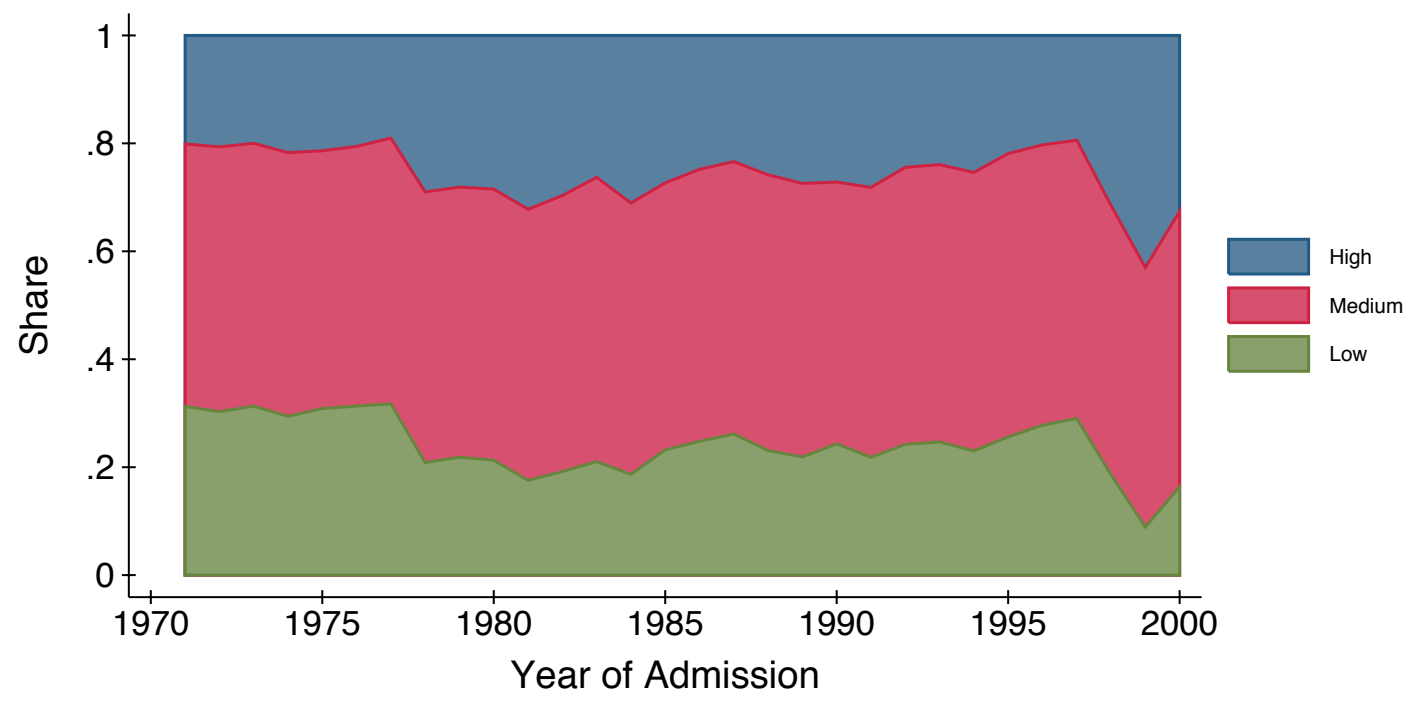

Source: Author's tabulations of Immigration and Naturalization Service data. Note: 48 contiguous states. 
Table 1

Determinants of Location Choice: Men

Pooled 1971-2000 with State Fixed Effects

(own-state marginal effects, $z$-ratios in parentheses)

\begin{tabular}{|c|c|c|c|c|c|}
\hline \multirow[b]{3}{*}{ Variable } & \multicolumn{5}{|c|}{ Visa Category } \\
\hline & \multicolumn{2}{|c|}{ Relatives of U.S. Citzens } & \multirow{2}{*}{$\begin{array}{c}\text { Relatives of } \\
\text { LPR }\end{array}$} & \multirow[b]{2}{*}{ Employment } & \multirow{2}{*}{$\begin{array}{c}\text { Refugees } \\
(1971-1990)\end{array}$} \\
\hline & Non-Quota & Quota & & & \\
\hline Expected Log(Wage) & $\begin{array}{r}.0256 \\
(8.19)\end{array}$ & $\begin{array}{c}-.0180 \\
(4.77)\end{array}$ & $\begin{array}{c}.0121 \\
(2.86)\end{array}$ & 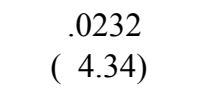 & $\begin{array}{c}.0648 \\
(11.51)\end{array}$ \\
\hline Unemployment Rate (\% points) & $\begin{array}{l}-.0003 \\
(1.77)\end{array}$ & $\begin{array}{c}.0004 \\
(1.68)\end{array}$ & $\begin{array}{c}.0008 \\
(2.45)\end{array}$ & $\begin{array}{l}-.0017 \\
(4.74)\end{array}$ & $\begin{array}{c}.0018 \\
(4.36)\end{array}$ \\
\hline Region of Birth as $\%$ of State Pop. & $\begin{array}{c}.0066 \\
(22.26)\end{array}$ & $\begin{array}{c}.0110 \\
(26.44)\end{array}$ & $\begin{array}{c}.0059 \\
(13.00)\end{array}$ & $\begin{array}{c}.0017 \\
(3.03)\end{array}$ & $\begin{array}{c}.0210 \\
(17.29)\end{array}$ \\
\hline Region of Birth as $\%$ of State Pop. Sq. $\div 100$ & $\begin{array}{l}-.0305 \\
(17.07)\end{array}$ & $\begin{array}{l}-.0606 \\
(21.54)\end{array}$ & $\begin{array}{l}-.0332 \\
(11.19)\end{array}$ & $\begin{array}{l}-.0069 \\
(1.66)\end{array}$ & $\begin{array}{c}-.0533 \\
(2.83)\end{array}$ \\
\hline$\%$ of Region of Birth Pop. in State & $\begin{array}{c}.0014 \\
(24.43)\end{array}$ & $\begin{array}{c}.0007 \\
(8.52)\end{array}$ & $\begin{array}{c}.0003 \\
(3.95)\end{array}$ & $\begin{array}{c}.0007 \\
(6.33)\end{array}$ & $\begin{array}{c}.0030 \\
(15.54)\end{array}$ \\
\hline$\%$ of Region of Birth Pop. in State Sq. $\div 100$ & $\begin{array}{l}-.0021 \\
(25.33)\end{array}$ & $\begin{array}{l}-.0014 \\
(11.81)\end{array}$ & $\begin{array}{c}.0001 \\
(1.24)\end{array}$ & $\begin{array}{l}-.0005 \\
(2.94)\end{array}$ & $\begin{array}{l}-.0062 \\
(20.76)\end{array}$ \\
\hline Foreign-Born \% of State Pop. & $\begin{array}{l}-.0013 \\
(5.89)\end{array}$ & $\begin{array}{c}.0004 \\
(1.53)\end{array}$ & $\begin{array}{c}.0011 \\
(3.17)\end{array}$ & $\begin{array}{c}.0030 \\
(9.45)\end{array}$ & $\begin{array}{l}-.0044 \\
(5.22)\end{array}$ \\
\hline Foreign-Born $\%$ of State Pop. Sq. $\div 100$ & $\begin{array}{c}.0022 \\
(4.38)\end{array}$ & $\begin{array}{l}-.0028 \\
(4.86)\end{array}$ & $\begin{array}{l}-.0048 \\
(6.29)\end{array}$ & $\begin{array}{c}-.0074 \\
(10.03)\end{array}$ & $\begin{array}{c}.0063 \\
(3.30)\end{array}$ \\
\hline Log (State Population) & $\begin{array}{c}.0162 \\
(10.09)\end{array}$ & $\begin{array}{c}.0199 \\
(9.64)\end{array}$ & $\begin{array}{c}.0301 \\
(11.54)\end{array}$ & $\begin{array}{c}.0363 \\
(12.98)\end{array}$ & $\begin{array}{c}.0005 \\
(0.08)\end{array}$ \\
\hline Distance from Country of Birth (1000 miles) & $\begin{array}{l}-.0162 \\
(20.72)\end{array}$ & $\begin{array}{l}-.0263 \\
(24.42)\end{array}$ & $\begin{array}{l}-.0347 \\
(29.12)\end{array}$ & $\begin{array}{c}-.0080 \\
(6.52)\end{array}$ & $\begin{array}{c}-.0077 \\
(2.48)\end{array}$ \\
\hline Distance from Countryof Birth Sq. $\div 100$ & $\begin{array}{c}.0660 \\
(10.37)\end{array}$ & $\begin{array}{r}.1329 \\
(16.04)\end{array}$ & $\begin{array}{c}.1948 \\
(20.92)\end{array}$ & $\begin{array}{r}.0166 \\
(1.71)\end{array}$ & $\begin{array}{c}.0446 \\
(2.08)\end{array}$ \\
\hline |State-Country of Birth Temp.| $\left({ }^{\circ} \mathrm{F}\right)$ & $\begin{array}{c}.0009 \\
(13.94)\end{array}$ & $\begin{array}{c}.0000 \\
(0.40)\end{array}$ & $\begin{array}{c}.0004 \\
(4.69)\end{array}$ & $\begin{array}{l}-.0005 \\
(5.05)\end{array}$ & $\begin{array}{c}-.0003 \\
(2.31)\end{array}$ \\
\hline $\mid$ State-Country of Birth Temp. Sq. $\mid \div 100$ & $\begin{array}{c}-.0016 \\
(8.24)\end{array}$ & $\begin{array}{c}.0008 \\
(3.82)\end{array}$ & $\begin{array}{c}.0001 \\
(0.29)\end{array}$ & $\begin{array}{c}.0024 \\
(8.51)\end{array}$ & $\begin{array}{c}.0005 \\
\left(\begin{array}{c}1.67)\end{array}\right)\end{array}$ \\
\hline |State-Country of Birth Precip.| (inches) & $\begin{array}{c}-.0004 \\
(15.32)\end{array}$ & $\begin{array}{c}-.0003 \\
(10.92)\end{array}$ & $\begin{array}{c}-.0004 \\
(13.94)\end{array}$ & $\begin{array}{c}-.0003 \\
(8.20)\end{array}$ & $\begin{array}{c}-.0003 \\
(6.32)\end{array}$ \\
\hline $\mid$ State-Country of Birth Precip. Sq. $\mid \div 100$ & $\begin{array}{c}.0003 \\
(9.32)\end{array}$ & $\begin{array}{c}.0002 \\
(6.68)\end{array}$ & $\begin{array}{c}.0005 \\
(11.14)\end{array}$ & $\begin{array}{c}.0003 \\
(4.58)\end{array}$ & $\begin{array}{c}.0001 \\
(1.26)\end{array}$ \\
\hline Pseudo- $R^{2}$ & .355 & .397 & .479 & .307 & .352 \\
\hline Number of Individuals & 30,419 & 25,384 & 24,597 & 11,755 & 16,267 \\
\hline Number of Observations & $1,460,112$ & $1,218,432$ & $1,180,656$ & 564,240 & 780,816 \\
\hline
\end{tabular}

Source: Author's calculations using INS and Census data.

Note: Estimated via conditional logit with robust standard errors. Choice set is 48 contiguous U.S. states. 
Table 2

Determinants of Location Choice: Women

Pooled 1971-2000 with State Fixed Effects

(own-state marginal effects, $z$-ratios in parentheses)

\begin{tabular}{|c|c|c|c|c|c|}
\hline \multirow[b]{3}{*}{ Variable } & \multicolumn{5}{|c|}{ Visa Category } \\
\hline & \multicolumn{2}{|c|}{ Relatives of U.S. Citzens } & \multirow{2}{*}{$\begin{array}{c}\text { Relatives of } \\
\text { LPR }\end{array}$} & \multirow[b]{2}{*}{ Employment } & \multirow{2}{*}{$\begin{array}{c}\text { Refugees } \\
(1971-1990)\end{array}$} \\
\hline & Non-Quota & Quota & & & \\
\hline Expected Log(Wage) & $\begin{array}{l}-.0005 \\
(0.17)\end{array}$ & $\begin{array}{c}-.0269 \\
(6.57)\end{array}$ & 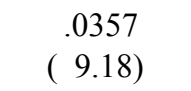 & $\begin{array}{l}-.0664 \\
(8.21)\end{array}$ & $\begin{array}{r}.0068 \\
\left(\begin{array}{c}6.76)\end{array}\right)\end{array}$ \\
\hline Unemployment Rate (\% points) & $\begin{array}{l}-.0006 \\
(3.26)\end{array}$ & $\begin{array}{c}.0013 \\
(4.63)\end{array}$ & $\begin{array}{l}-.0003 \\
(0.97)\end{array}$ & $\begin{array}{l}-.0004 \\
(0.58)\end{array}$ & $\begin{array}{l}-.0030 \\
(6.12)\end{array}$ \\
\hline Region of Birth as $\%$ of State Pop. & $\begin{array}{c}.0060 \\
(27.15)\end{array}$ & $\begin{array}{c}.0098 \\
(23.20)\end{array}$ & $\begin{array}{c}.0048 \\
(14.80)\end{array}$ & $\begin{array}{l}-.0048 \\
(5.98)\end{array}$ & $\begin{array}{c}.0022 \\
\left(\begin{array}{c}1.11)\end{array}\right)\end{array}$ \\
\hline Region of Birth as $\%$ of State Pop. Sq. $\div 100$ & $\begin{array}{l}-.0257 \\
(20.03)\end{array}$ & $\begin{array}{l}-.0544 \\
(18.56)\end{array}$ & $\begin{array}{l}-.0215 \\
(11.94)\end{array}$ & $\begin{array}{c}.0503 \\
(8.29)\end{array}$ & $\begin{array}{r}.1772 \\
(3.87)\end{array}$ \\
\hline$\%$ of Region of Birth Pop. in State & $\begin{array}{c}.0013 \\
(29.12)\end{array}$ & $\begin{array}{c}.0008 \\
(9.68)\end{array}$ & $\begin{array}{c}.0009 \\
(14.01)\end{array}$ & $\begin{array}{c}.0011 \\
(8.25)\end{array}$ & $\begin{array}{c}.0058 \\
(28.09)\end{array}$ \\
\hline$\%$ of Region of Birth Pop. in State Sq. $\div 100$ & $\begin{array}{l}-.0017 \\
(25.88)\end{array}$ & $\begin{array}{l}-.0014 \\
(11.42)\end{array}$ & $\begin{array}{c}-.0007 \\
(6.96)\end{array}$ & $\begin{array}{c}-.0008 \\
(3.56)\end{array}$ & $\begin{array}{l}-.0099 \\
(28.19)\end{array}$ \\
\hline Foreign-Born \% of State Pop. & $\begin{array}{c}.0004 \\
(2.85)\end{array}$ & $\begin{array}{c}.0014 \\
(4.93)\end{array}$ & $\begin{array}{c}.0005 \\
(1.69)\end{array}$ & $\begin{array}{c}.0044 \\
(7.69)\end{array}$ & $\begin{array}{c}-.0053 \\
(7.48)\end{array}$ \\
\hline Foreign-Born $\%$ of State Pop. Sq. $\div 100$ & $\begin{array}{l}-.0009 \\
(2.55)\end{array}$ & $\begin{array}{c}-.0056 \\
(9.33)\end{array}$ & $\begin{array}{l}-.0026 \\
(4.25)\end{array}$ & $\begin{array}{c}-.0118 \\
(8.98)\end{array}$ & $\begin{array}{r}.0090 \\
(4.81)\end{array}$ \\
\hline Log (State Population) & $\begin{array}{c}.0057 \\
(4.92)\end{array}$ & $\begin{array}{c}.0201 \\
(9.05)\end{array}$ & $\begin{array}{c}.0231 \\
(10.91)\end{array}$ & $\begin{array}{c}.0423 \\
(8.84)\end{array}$ & $\begin{array}{c}.0554 \\
(9.45)\end{array}$ \\
\hline Distance from Country of Birth (1000 miles) & $\begin{array}{c}-.0122 \\
(19.92)\end{array}$ & $\begin{array}{l}-.0268 \\
(24.44)\end{array}$ & $\begin{array}{l}-.0321 \\
(30.24)\end{array}$ & $\begin{array}{l}-.0065 \\
(3.08)\end{array}$ & $\begin{array}{c}.0087 \\
(6.53)\end{array}$ \\
\hline Distance from Countryof Birth Sq. $\div 100$ & $\begin{array}{c}.0497 \\
(9.77)\end{array}$ & $\begin{array}{c}.1365 \\
(15.86)\end{array}$ & $\begin{array}{c}.1737 \\
(20.69)\end{array}$ & $\begin{array}{c}-.0048 \\
(0.26)\end{array}$ & $\begin{array}{l}-.0362 \\
(3.36)\end{array}$ \\
\hline |State-Country of Birth Temp.| $\left({ }^{\circ} \mathrm{F}\right)$ & $\begin{array}{c}.0003 \\
(7.39)\end{array}$ & $\begin{array}{c}.0001 \\
(0.90)\end{array}$ & $\begin{array}{c}.0002 \\
(2.15)\end{array}$ & $\begin{array}{c}-.0008 \\
(5.51)\end{array}$ & $\begin{array}{c}-.0003 \\
(2.28)\end{array}$ \\
\hline $\mid$ State-Country of Birth Temp. Sq. $\mid \div 100$ & $\begin{array}{c}-.0003 \\
(1.95)\end{array}$ & $\begin{array}{c}.0008 \\
(3.40)\end{array}$ & $\begin{array}{c}.0005 \\
(2.39)\end{array}$ & $\begin{array}{c}.0044 \\
(9.07)\end{array}$ & $\begin{array}{c}.0002 \\
(0.47)\end{array}$ \\
\hline |State-Country of Birth Precip.| (inches) & $\begin{array}{c}-.0004 \\
(19.52)\end{array}$ & $\begin{array}{c}-.0003 \\
(9.66)\end{array}$ & $\begin{array}{c}-.0004 \\
(14.92)\end{array}$ & $\begin{array}{c}-.0004 \\
(7.22)\end{array}$ & $\begin{array}{c}-.0001 \\
(2.15)\end{array}$ \\
\hline |State-Country of Birth Precip. Sq. $\mid \div 100$ & $\begin{array}{c}.0003 \\
(11.95)\end{array}$ & $\begin{array}{c}.0002 \\
(4.33)\end{array}$ & $\begin{array}{c}.0004 \\
(9.42)\end{array}$ & $\begin{array}{c}.0002 \\
(3.36)\end{array}$ & $\begin{array}{c}.0002 \\
(1.26)\end{array}$ \\
\hline Pseudo- $R^{2}$ & .312 & .400 & .452 & .406 & .353 \\
\hline Number of Individuals & 54,273 & 24,597 & 31,299 & 6,921 & 9,250 \\
\hline Number of Observations & $2,605,104$ & $1,180,656$ & $1,502,352$ & 332,208 & 444,000 \\
\hline
\end{tabular}

Source: Author's calculations using INS and Census data.

Note: Estimated via conditional logit with robust standard errors. Choice set is 48 contiguous U.S. states. 
Table 3

Determinants of Location Choice: Family of U.S. Citizens (Non-Quota)

(own-state marginal effects, $z$-ratios in parentheses)

\begin{tabular}{|c|c|c|c|c|c|c|c|c|}
\hline \multirow[b]{2}{*}{ Variable } & \multicolumn{4}{|c|}{ Men } & \multicolumn{4}{|c|}{ Women } \\
\hline & 1971 & 1980 & 1990 & 2000 & 1971 & 1980 & 1990 & 2000 \\
\hline Expected Log(Wage) & $\begin{array}{c}.0275 \\
(4.57)\end{array}$ & $\begin{array}{c}.0385 \\
(9.37)\end{array}$ & $\begin{array}{r}.0426 \\
(12.89)\end{array}$ & $\begin{array}{c}.0253 \\
(5.12)\end{array}$ & $\begin{array}{c}.0011 \\
(0.27)\end{array}$ & $\begin{array}{c}.0118 \\
(2.73)\end{array}$ & $\begin{array}{c}.0254 \\
(6.08)\end{array}$ & $\begin{array}{r}.0259 \\
(6.79)\end{array}$ \\
\hline Unemployment Rate (\% points) & $\begin{array}{c}-.0027 \\
(4.33)\end{array}$ & $\begin{array}{c}-.0009 \\
(3.77)\end{array}$ & $\begin{array}{c}-.0009 \\
(3.07)\end{array}$ & $\begin{array}{c}-.0002 \\
(0.31)\end{array}$ & $\begin{array}{c}-.0015 \\
(4.11)\end{array}$ & $\begin{array}{c}-.0011 \\
(4.39)\end{array}$ & $\begin{array}{c}.0001 \\
(0.38)\end{array}$ & $\begin{array}{c}.0003 \\
(0.57)\end{array}$ \\
\hline Region of Birth as $\%$ of State Pop. & $\begin{array}{c}.0280 \\
(12.93)\end{array}$ & $\begin{array}{c}.0245 \\
(21.59)\end{array}$ & $\begin{array}{r}.0144 \\
(25.31)\end{array}$ & $\begin{array}{c}.0096 \\
(14.82)\end{array}$ & $\begin{array}{r}.0246 \\
(14.49)\end{array}$ & $\begin{array}{r}.0213 \\
(19.23)\end{array}$ & $\begin{array}{c}.0112 \\
(16.73)\end{array}$ & $\begin{array}{r}.0073 \\
(17.26)\end{array}$ \\
\hline Region of Birth as $\%$ of State Pop. Sq. $\div 100$ & $\begin{array}{l}-.6314 \\
(10.34)\end{array}$ & $\begin{array}{l}-.3147 \\
(16.35)\end{array}$ & $\begin{array}{l}-.1060 \\
(22.11)\end{array}$ & $\begin{array}{l}-.0446 \\
(12.80)\end{array}$ & $\begin{array}{c}-.5253 \\
(10.83)\end{array}$ & $\begin{array}{l}-.2528 \\
(14.02)\end{array}$ & $\begin{array}{l}-.0766 \\
(14.13)\end{array}$ & $\begin{array}{l}-.0277 \\
(12.10)\end{array}$ \\
\hline$\%$ of Region of Birth Pop. in State & $\begin{array}{c}.0010 \\
(7.12)\end{array}$ & $\begin{array}{l}-.0003 \\
(2.37)\end{array}$ & $\begin{array}{c}-.0003 \\
(3.12)\end{array}$ & $\begin{array}{c}.0002 \\
(0.97)\end{array}$ & $\begin{array}{c}.0005 \\
(4.33)\end{array}$ & $\begin{array}{l}-.0002 \\
(1.45)\end{array}$ & $\begin{array}{c}.0003 \\
(2.25)\end{array}$ & $\begin{array}{r}.0009 \\
(7.45)\end{array}$ \\
\hline$\%$ of Region of Birth Pop. in State Sq. $\div 100$ & $\begin{array}{c}-.0014 \\
(6.30)\end{array}$ & $\begin{array}{c}.0007 \\
(2.63)\end{array}$ & $\begin{array}{c}.0008 \\
(4.39)\end{array}$ & $\begin{array}{c}.0003 \\
(0.77)\end{array}$ & $\begin{array}{c}-.0002 \\
(1.31)\end{array}$ & $\begin{array}{c}.0005 \\
(2.27)\end{array}$ & $\begin{array}{c}.0000 \\
(0.11)\end{array}$ & $\begin{array}{c}-.0012 \\
(5.10)\end{array}$ \\
\hline Foreign-Born \% of State Pop. & $\begin{array}{c}.0065 \\
(10.02)\end{array}$ & $\begin{array}{c}.0037 \\
(9.24)\end{array}$ & $\begin{array}{c}.0032 \\
(17.80)\end{array}$ & $\begin{array}{c}.0019 \\
(8.32)\end{array}$ & $\begin{array}{c}.0033 \\
(8.45)\end{array}$ & $\begin{array}{c}.0028 \\
(9.05)\end{array}$ & $\begin{array}{c}.0024 \\
(13.10)\end{array}$ & $\begin{array}{c}.0019 \\
(12.91)\end{array}$ \\
\hline Foreign-Born $\%$ of State Pop. Sq. $\div 100$ & $\begin{array}{c}-.0321 \\
(7.44)\end{array}$ & $\begin{array}{c}-.0092 \\
(4.03)\end{array}$ & $\begin{array}{c}-.0063 \\
(8.44)\end{array}$ & $\begin{array}{c}-.0029 \\
(3.55)\end{array}$ & $\begin{array}{c}-.0150 \\
(5.73)\end{array}$ & $\begin{array}{c}-.0093 \\
(5.12)\end{array}$ & $\begin{array}{c}-.0068 \\
(8.61)\end{array}$ & $\begin{array}{c}-.0043 \\
(7.98)\end{array}$ \\
\hline Log (State Population) & $\begin{array}{c}.0146 \\
(19.75)\end{array}$ & $\begin{array}{c}.0174 \\
(28.18)\end{array}$ & $\begin{array}{r}.0156 \\
(29.13)\end{array}$ & $\begin{array}{c}.0165 \\
(20.87)\end{array}$ & $\begin{array}{c}.0153 \\
(31.76)\end{array}$ & $\begin{array}{c}.0192 \\
(37.28)\end{array}$ & $\begin{array}{c}.0158 \\
(29.62)\end{array}$ & $\begin{array}{c}.0156 \\
(31.63)\end{array}$ \\
\hline Distance from Country of Birth (1000 miles) & $\begin{array}{c}-.0159 \\
(8.21)\end{array}$ & $\begin{array}{c}-.0113 \\
(7.79)\end{array}$ & $\begin{array}{c}-.0160 \\
(12.77)\end{array}$ & $\begin{array}{c}-.0131 \\
(6.74)\end{array}$ & $\begin{array}{c}-.0144 \\
(9.34)\end{array}$ & $\begin{array}{c}-.0096 \\
(7.12)\end{array}$ & $\begin{array}{c}-.0123 \\
(8.78)\end{array}$ & $\begin{array}{c}-.0118 \\
(9.44)\end{array}$ \\
\hline Distance from Countryof Birth Sq. $\div 100$ & $\begin{array}{c}.0598 \\
(3.31)\end{array}$ & $\begin{array}{c}.0360 \\
(2.88)\end{array}$ & $\begin{array}{c}.0727 \\
(7.31)\end{array}$ & $\begin{array}{c}.0573 \\
(3.73)\end{array}$ & $\begin{array}{c}.0692 \\
(4.94)\end{array}$ & $\begin{array}{c}.0369 \\
(3.21)\end{array}$ & $\begin{array}{c}.0644 \\
(5.67)\end{array}$ & $\begin{array}{r}.0559 \\
(5.62)\end{array}$ \\
\hline Log(State Land Area) & $\begin{array}{c}.0065 \\
(11.40)\end{array}$ & $\begin{array}{c}.0030 \\
(8.71)\end{array}$ & $\begin{array}{r}.0032 \\
(8.32)\end{array}$ & $\begin{array}{c}.0003 \\
(0.66)\end{array}$ & $\begin{array}{r}.0037 \\
(9.62)\end{array}$ & $\begin{array}{c}.0011 \\
(3.69)\end{array}$ & $\begin{array}{c}.0022 \\
(6.06)\end{array}$ & $\begin{array}{c}-.0002 \\
(0.75)\end{array}$ \\
\hline |State-Country of Birth Temp.| $\left({ }^{\circ} \mathrm{F}\right)$ & $\begin{array}{c}.0011 \\
(6.03)\end{array}$ & $\begin{array}{c}.0008 \\
(6.17)\end{array}$ & $\begin{array}{c}.0003 \\
(3.27)\end{array}$ & $\begin{array}{c}.0003 \\
(1.95)\end{array}$ & $\begin{array}{c}.0006 \\
(5.31)\end{array}$ & $\begin{array}{c}.0006 \\
(6.68)\end{array}$ & $\begin{array}{c}-.0001 \\
(1.00)\end{array}$ & $\begin{array}{c}.0001 \\
\left(\begin{array}{c}0.68)\end{array}\right)\end{array}$ \\
\hline $\mid$ State-Country of Birth Temp. Sq. $\mid \div 100$ & $\begin{array}{c}-.0017 \\
(3.24)\end{array}$ & $\begin{array}{c}-.0013 \\
(3.41)\end{array}$ & $\begin{array}{c}.0004 \\
(1.23)\end{array}$ & $\begin{array}{c}.0001 \\
(0.28)\end{array}$ & $\begin{array}{c}-.0013 \\
(3.88)\end{array}$ & $\begin{array}{c}-.0013 \\
(4.81)\end{array}$ & $\begin{array}{c}.0010 \\
(3.62)\end{array}$ & $\begin{array}{r}.0002 \\
(0.62)\end{array}$ \\
\hline |State-Country of Birth Precip.| (inches) & $\begin{array}{c}-.0005 \\
(6.92)\end{array}$ & $\begin{array}{c}-.0006 \\
(10.51)\end{array}$ & $\begin{array}{c}-.0004 \\
(9.92)\end{array}$ & $\begin{array}{c}-.0001 \\
(1.67)\end{array}$ & $\begin{array}{c}-.0003 \\
(6.33)\end{array}$ & $\begin{array}{c}-.0005 \\
(10.15)\end{array}$ & $\begin{array}{c}-.0003 \\
(7.12)\end{array}$ & $\begin{array}{c}-.0002 \\
(5.46)\end{array}$ \\
\hline $\mid$ State-Country of Birth Precip. Sq. $\mid \div 100$ & $\begin{array}{c}.0005 \\
(4.22)\end{array}$ & $\begin{array}{c}.0005 \\
(6.24)\end{array}$ & $\begin{array}{c}.0003 \\
(5.88)\end{array}$ & $\begin{array}{c}-.0002 \\
(2.04)\end{array}$ & $\begin{array}{r}.0003 \\
(4.12)\end{array}$ & $\begin{array}{r}.0006 \\
(8.80)\end{array}$ & $\begin{array}{r}.0002 \\
(3.95)\end{array}$ & $\begin{array}{c}-.0000 \\
(0.53)\end{array}$ \\
\hline $\begin{array}{l}\text { Pseudo- } R^{2} \\
\text { Number of Individuals } \\
\text { Number of Observations }\end{array}$ & $\begin{array}{c}.402 \\
4,787 \\
229,776\end{array}$ & $\begin{array}{c}.358 \\
8,258 \\
396,384\end{array}$ & $\begin{array}{c}.356 \\
11,745 \\
563,760\end{array}$ & $\begin{array}{c}.324 \\
5,629 \\
270,192\end{array}$ & $\begin{array}{c}.262 \\
8,020 \\
384,960\end{array}$ & $\begin{array}{c}.303 \\
11,460 \\
550,080\end{array}$ & $\begin{array}{c}.327 \\
10,367 \\
497,616\end{array}$ & $\begin{array}{c}.326 \\
10,421 \\
500,208\end{array}$ \\
\hline
\end{tabular}

Source: Author's calculations using INS and Census data.

Note: Estimated via conditional logit with robust standard errors. Choice set is 48 contiguous U.S. states. 
Table 4

Determinants of Location Choice: Family of U.S. Citizens (Quota)

(own-state marginal effects, $z$-ratios in parentheses)

\begin{tabular}{|c|c|c|c|c|c|c|c|c|}
\hline \multirow[b]{2}{*}{ Variable } & \multicolumn{4}{|c|}{ Men } & \multicolumn{4}{|c|}{ Women } \\
\hline & 1971 & 1980 & 1990 & 2000 & 1971 & 1980 & 1990 & 2000 \\
\hline ed Log(Wage) & & & & & & & & $\begin{array}{r}.0546 \\
(7.71)\end{array}$ \\
\hline Unemployment Rate (\% points) & $\begin{array}{l}-.0006 \\
(0.78)\end{array}$ & $\begin{array}{l}-.0009 \\
(3.33)\end{array}$ & $\begin{array}{l}-.0007 \\
(2.24)\end{array}$ & $\begin{array}{r}.0034 \\
(4.38)\end{array}$ & $\begin{array}{l}-.0016 \\
(2.35)\end{array}$ & $\begin{array}{l}-.0002 \\
(0.58)\end{array}$ & $\begin{array}{r}.0014 \\
(2.61)\end{array}$ & $\begin{array}{r}.0033 \\
\text { ( } 3.54)\end{array}$ \\
\hline egion of Birth as \% of State Pop. & $\begin{array}{c}.0281 \\
(10.59)\end{array}$ & $\begin{array}{c}.0317 \\
(24.66)\end{array}$ & $\begin{array}{c}.0158 \\
(21.10)\end{array}$ & & $\begin{array}{r}.0269 \\
(10.16)\end{array}$ & & & $\begin{array}{r}.0097 \\
(10.69)\end{array}$ \\
\hline egion of Birth as $\%$ of State Pop. Sq. $\div 100$ & $\begin{array}{l}-.4042 \\
(7.65)\end{array}$ & $\begin{array}{l}-.4242 \\
(22.66)\end{array}$ & $\begin{array}{l}-.1040 \\
(18.28)\end{array}$ & $\begin{array}{l}-.0499 \\
(10.25)\end{array}$ & $\begin{array}{l}-.4066 \\
(7.74)\end{array}$ & $\begin{array}{c}-.3784 \\
(19.75)\end{array}$ & $\begin{array}{c}-.0999 \\
(13.08)\end{array}$ & $\begin{array}{l}-.0424 \\
(8.57)\end{array}$ \\
\hline te & $\begin{array}{c}.0023 \\
(6.55)\end{array}$ & $\begin{array}{l}-.0014 \\
(8.53)\end{array}$ & $\begin{array}{c}-.0001 \\
(0.63)\end{array}$ & $\begin{array}{c}-.0001 \\
(0.26)\end{array}$ & $\begin{array}{c}.0032 \\
(8.44)\end{array}$ & & $\begin{array}{r}.0000 \\
(0.23)\end{array}$ & $\begin{array}{l}-.0000 \\
(0.15)\end{array}$ \\
\hline f Rirth Pon & $\begin{array}{l}-.0035 \\
(4.48)\end{array}$ & $\begin{array}{c}.0021 \\
(8.15)\end{array}$ & $\begin{array}{c}.0001 \\
(0.50)\end{array}$ & & & $\begin{array}{r}.0019 \\
(7.09)\end{array}$ & $\begin{array}{r}.0000 \\
(0.08)\end{array}$ & $\begin{array}{r}.0001 \\
(0.30)\end{array}$ \\
\hline Foreign-Born $\%$ of State Pop. & $\begin{array}{r}.0067 \\
(6.54)\end{array}$ & $\begin{array}{c}.0032 \\
(8.06)\end{array}$ & $\begin{array}{r}.0039 \\
(19.87)\end{array}$ & $\begin{array}{c}.0028 \\
(10.23)\end{array}$ & $\begin{array}{r}.0079 \\
(7.58)\end{array}$ & $\begin{array}{c}.0032 \\
(7.59)\end{array}$ & $\begin{array}{c}.0029 \\
(10.88)\end{array}$ & $\begin{array}{r}.0020 \\
(7.99)\end{array}$ \\
\hline 0 & $\begin{array}{l}-.0494 \\
(7.06)\end{array}$ & $\begin{array}{l}-.0009 \\
(0.37)\end{array}$ & $\begin{array}{l}-.0115 \\
(13.22)\end{array}$ & & $\begin{array}{l}-.0634 \\
(9.32)\end{array}$ & $\begin{array}{c}-.0002 \\
(0.07)\end{array}$ & & $\begin{array}{l}-.0048 \\
(4.96)\end{array}$ \\
\hline (Ctoto & $\begin{array}{c}.0182 \\
(14.07)\end{array}$ & $\begin{array}{c}.0261 \\
(33.92)\end{array}$ & $\begin{array}{c}.0220 \\
(33.20)\end{array}$ & & & $\begin{array}{r}.0235 \\
(28.26)\end{array}$ & $\begin{array}{c}.0229 \\
(25.61)\end{array}$ & $\begin{array}{r}.0260 \\
(25.81)\end{array}$ \\
\hline Distance from Country of Birth (10 & $\begin{array}{c}.0102 \\
(2.23)\end{array}$ & $\begin{array}{l}-.0312 \\
(18.89)\end{array}$ & $\begin{array}{l}-.0225 \\
(14.70)\end{array}$ & $\begin{array}{l}-.0271 \\
(11.87)\end{array}$ & $\begin{array}{c}-.0023 \\
(0.55)\end{array}$ & $\begin{array}{l}-.0290 \\
(17.70)\end{array}$ & & $\begin{array}{l}-.0271 \\
(12.54)\end{array}$ \\
\hline (1) & $\begin{array}{l}-.0761 \\
(2.04)\end{array}$ & $\begin{array}{r}.1898 \\
(14.89)\end{array}$ & $\begin{array}{r}.1144 \\
(9.95)\end{array}$ & & $\begin{array}{c}.0103 \\
(0.30)\end{array}$ & $\begin{array}{r}.1801 \\
(13.76)\end{array}$ & & $\begin{array}{r}.1226 \\
(7.47)\end{array}$ \\
\hline 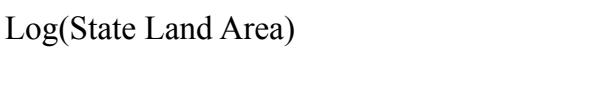 & $\begin{array}{l}-.0040 \\
(3.90)\end{array}$ & $\begin{array}{l}-.0022 \\
(6.06)\end{array}$ & $\begin{array}{c}.0011 \\
(2.87)\end{array}$ & $\begin{array}{l}-.0040 \\
(7.01)\end{array}$ & $\begin{array}{l}-.0021 \\
(2.09)\end{array}$ & $\begin{array}{l}-.0027 \\
(6.72)\end{array}$ & $\begin{array}{r}.0007 \\
(1.36)\end{array}$ & $\begin{array}{l}-.0031 \\
(5.86)\end{array}$ \\
\hline State-Count & $\begin{array}{c}.0001 \\
(0.51)\end{array}$ & $\begin{array}{l}-.0003 \\
(2.25)\end{array}$ & $\begin{array}{l}-.0004 \\
(3.55)\end{array}$ & $\begin{array}{l}-.0005 \\
(2.76)\end{array}$ & $\begin{array}{c}.0001 \\
(0.60)\end{array}$ & $\begin{array}{l}-.0001 \\
(1.18)\end{array}$ & $\begin{array}{l}-.0004 \\
(2.76)\end{array}$ & $\begin{array}{l}-.0003 \\
(1.95)\end{array}$ \\
\hline $\mid$ State-Country of Birth Temp. Sq. $\mid \div 100$ & $\begin{array}{l}-.0006 \\
(0.79)\end{array}$ & $\begin{array}{r}.0026 \\
(8.24)\end{array}$ & $\begin{array}{c}.0018 \\
(6.02)\end{array}$ & $\begin{array}{c}.0017 \\
(3.55)\end{array}$ & $\begin{array}{l}-.0010 \\
(1.12)\end{array}$ & $\begin{array}{r}.0025 \\
\left(\begin{array}{c}7.66)\end{array}\right.\end{array}$ & $\begin{array}{r}.0020 \\
(5.25)\end{array}$ & $\begin{array}{r}.0020 \\
(4.21)\end{array}$ \\
\hline |State-Country of Birth Precip.| (inches) & $\begin{array}{l}-.0005 \\
(4.67)\end{array}$ & $\begin{array}{l}-.0004 \\
(7.27)\end{array}$ & $\begin{array}{l}-.0003 \\
(7.69)\end{array}$ & $\begin{array}{l}-.0002 \\
(2.96)\end{array}$ & $\begin{array}{l}-.0004 \\
(3.39)\end{array}$ & $\begin{array}{r}-.0003 \\
(5.53)\end{array}$ & $\begin{array}{l}-.0003 \\
(6.35)\end{array}$ & $\begin{array}{c}-.0002 \\
\text { ( } 3.99)\end{array}$ \\
\hline $\mid$ State-Country of Birth Precip. Sq. $\mid \div 100$ & $\begin{array}{r}.0009 \\
(4.51)\end{array}$ & $\begin{array}{r}.0003 \\
(4.95)\end{array}$ & $\begin{array}{r}.0002 \\
(4.52)\end{array}$ & $\begin{array}{r}.0001 \\
(1.22)\end{array}$ & $\begin{array}{r}.0008 \\
(3.87)\end{array}$ & $\begin{array}{c}.0002 \\
(3.25)\end{array}$ & $\begin{array}{c}.0002 \\
(3.90)\end{array}$ & $\begin{array}{r}.0001 \\
(1.41)\end{array}$ \\
\hline $2^{2}$ & .397 & $\begin{array}{l}.397 \\
9214\end{array}$ & .405 & .388 & .406 & .403 & .405 & $\begin{array}{l}.381 \\
4.006\end{array}$ \\
\hline Number of Observations & 130,704 & $\begin{array}{r}9,214 \\
442,272 \\
\end{array}$ & 614,304 & 244,320 & 122,976 & $\begin{array}{r}8,354 \\
400,992 \\
\end{array}$ & $\begin{array}{r}7,052 \\
338,496\end{array}$ & $\begin{array}{r}4,006 \\
192,288\end{array}$ \\
\hline
\end{tabular}

Source: Author's calculations using INS and Census data.

Note: Estimated via conditional logit with robust standard errors. Choice set is 48 contiguous U.S. states. 
Table 5

Determinants of Location Choice: Family of Legal Permanent Residents

(own-state marginal effects, $z$-ratios in parentheses)

\begin{tabular}{|c|c|c|c|c|c|c|c|c|}
\hline \multirow[b]{2}{*}{ Variable } & \multicolumn{4}{|c|}{ Men } & \multicolumn{4}{|c|}{ Women } \\
\hline & 1971 & 1980 & 1990 & 2000 & 1971 & 1980 & 1990 & 2000 \\
\hline Expected Log(Wage) & $\begin{array}{c}.0439 \\
(3.48)\end{array}$ & $\begin{array}{c}.0374 \\
(8.43)\end{array}$ & $\begin{array}{c}.0665 \\
(16.28)\end{array}$ & $\begin{array}{c}.0287 \\
(3.57)\end{array}$ & $\begin{array}{r}.0642 \\
(6.72)\end{array}$ & $\begin{array}{r}.0456 \\
(8.41)\end{array}$ & $\begin{array}{c}.0770 \\
(10.71)\end{array}$ & $\begin{array}{r}.0298 \\
(5.65)\end{array}$ \\
\hline Unemployment Rate (\% points) & $\begin{array}{c}-.0008 \\
(0.75)\end{array}$ & $\begin{array}{c}.0008 \\
(2.77)\end{array}$ & $\begin{array}{c}-.0007 \\
(1.65)\end{array}$ & $\begin{array}{c}.0095 \\
(8.57)\end{array}$ & $\begin{array}{c}-.0018 \\
(2.60)\end{array}$ & $\begin{array}{c}.0006 \\
(2.10)\end{array}$ & $\begin{array}{c}.0009 \\
(1.30)\end{array}$ & $\begin{array}{r}.0045 \\
(5.57)\end{array}$ \\
\hline Region of Birth as $\%$ of State Pop. & $\begin{array}{c}.0190 \\
(4.90)\end{array}$ & $\begin{array}{r}.0300 \\
(19.52)\end{array}$ & $\begin{array}{c}.0098 \\
(12.22)\end{array}$ & $\begin{array}{c}.0121 \\
(10.85)\end{array}$ & $\begin{array}{r}.0266 \\
(8.75)\end{array}$ & $\begin{array}{c}.0337 \\
(23.96)\end{array}$ & $\begin{array}{r}.0079 \\
(7.66)\end{array}$ & $\begin{array}{c}.0087 \\
(15.06)\end{array}$ \\
\hline Region of Birth as $\%$ of State Pop. Sq. $\div 100$ & $\begin{array}{c}-.1422 \\
(1.72)\end{array}$ & $\begin{array}{l}-.4967 \\
(23.56)\end{array}$ & $\begin{array}{c}-.0836 \\
(12.93)\end{array}$ & $\begin{array}{c}-.0522 \\
(8.94)\end{array}$ & $\begin{array}{c}-.4123 \\
(6.19)\end{array}$ & $\begin{array}{l}-.4952 \\
(25.38)\end{array}$ & $\begin{array}{c}-.0677 \\
(7.93)\end{array}$ & $\begin{array}{c}-.0437 \\
(13.53)\end{array}$ \\
\hline$\%$ of Region of Birth Pop. in State & $\begin{array}{c}.0021 \\
(4.90)\end{array}$ & $\begin{array}{c}-.0020 \\
(10.72)\end{array}$ & $\begin{array}{c}-.0007 \\
(4.88)\end{array}$ & $\begin{array}{c}-.0001 \\
(0.27)\end{array}$ & $\begin{array}{c}.0020 \\
(6.08)\end{array}$ & $\begin{array}{c}-.0018 \\
(10.20)\end{array}$ & $\begin{array}{c}-.0004 \\
(2.20)\end{array}$ & $\begin{array}{c}.0011 \\
(6.06)\end{array}$ \\
\hline$\%$ of Region of Birth Pop. in State Sq. $\div 100$ & $\begin{array}{c}-.0044 \\
(5.26)\end{array}$ & $\begin{array}{c}.0046 \\
(15.90)\end{array}$ & $\begin{array}{c}.0023 \\
(10.20)\end{array}$ & $\begin{array}{c}.0000 \\
(0.08)\end{array}$ & $\begin{array}{c}-.0034 \\
(5.12)\end{array}$ & $\begin{array}{c}.0037 \\
(13.72)\end{array}$ & $\begin{array}{r}.0018 \\
(6.03)\end{array}$ & $\begin{array}{c}-.0016 \\
(4.23)\end{array}$ \\
\hline Foreign-Born $\%$ of State Pop. & $\begin{array}{r}.0088 \\
(6.19)\end{array}$ & $\begin{array}{c}.0064 \\
(12.80)\end{array}$ & $\begin{array}{c}.0065 \\
(26.89)\end{array}$ & $\begin{array}{c}.0032 \\
(8.69)\end{array}$ & $\begin{array}{c}.0045 \\
(4.72)\end{array}$ & $\begin{array}{c}.0050 \\
(11.26)\end{array}$ & $\begin{array}{c}.0056 \\
(17.94)\end{array}$ & $\begin{array}{r}.0020 \\
(7.36)\end{array}$ \\
\hline Foreign-Born $\%$ of State Pop. Sq. $\div 100$ & $\begin{array}{c}-.0502 \\
(5.32)\end{array}$ & $\begin{array}{c}-.0149 \\
(5.30)\end{array}$ & $\begin{array}{c}-.0182 \\
(19.00)\end{array}$ & $\begin{array}{c}-.0081 \\
(6.20)\end{array}$ & $\begin{array}{c}-.0343 \\
(5.41)\end{array}$ & $\begin{array}{c}-.0139 \\
(5.52)\end{array}$ & $\begin{array}{c}-.0166 \\
(13.41)\end{array}$ & $\begin{array}{c}-.0039 \\
(3.96)\end{array}$ \\
\hline Log (State Population) & $\begin{array}{c}.0231 \\
(12.49)\end{array}$ & $\begin{array}{c}.0289 \\
(28.14)\end{array}$ & $\begin{array}{r}.0264 \\
(27.39)\end{array}$ & $\begin{array}{c}.0250 \\
(17.16)\end{array}$ & $\begin{array}{c}.0225 \\
(17.18)\end{array}$ & $\begin{array}{c}.0286 \\
(31.29)\end{array}$ & $\begin{array}{c}.0250 \\
(21.09)\end{array}$ & $\begin{array}{r}.0160 \\
(20.06)\end{array}$ \\
\hline Distance from Country of Birth (1000 miles) & $\begin{array}{c}.0037 \\
(0.63)\end{array}$ & $\begin{array}{c}-.0344 \\
(18.87)\end{array}$ & $\begin{array}{c}-.0274 \\
(18.17)\end{array}$ & $\begin{array}{c}-.0166 \\
(5.69)\end{array}$ & $\begin{array}{c}.0187 \\
(3.73)\end{array}$ & $\begin{array}{c}-.0288 \\
(16.23)\end{array}$ & $\begin{array}{c}-.0304 \\
(14.54)\end{array}$ & $\begin{array}{c}-.0169 \\
(8.61)\end{array}$ \\
\hline Distance from Countryof Birth Sq. $\div 100$ & $\begin{array}{c}-.0898 \\
(1.93)\end{array}$ & $\begin{array}{c}.2198 \\
(14.66)\end{array}$ & $\begin{array}{r}.1546 \\
(12.84)\end{array}$ & $\begin{array}{c}.0816 \\
(3.58)\end{array}$ & $\begin{array}{c}-.2300 \\
(5.98)\end{array}$ & $\begin{array}{c}.1773 \\
(12.49)\end{array}$ & $\begin{array}{c}.1827 \\
(10.64)\end{array}$ & $\begin{array}{r}.0495 \\
(3.07)\end{array}$ \\
\hline Log(State Land Area) & $\begin{array}{c}-.0036 \\
(2.77)\end{array}$ & $\begin{array}{c}-.0039 \\
(8.58)\end{array}$ & $\begin{array}{c}-.0016 \\
(2.96)\end{array}$ & $\begin{array}{c}-.0067 \\
(8.43)\end{array}$ & $\begin{array}{c}-.0052 \\
(6.20)\end{array}$ & $\begin{array}{c}-.0020 \\
(4.91)\end{array}$ & $\begin{array}{c}-.0017 \\
(2.63)\end{array}$ & $\begin{array}{c}-.0037 \\
(8.43)\end{array}$ \\
\hline |State-Country of Birth Temp.| $\left({ }^{\circ} \mathrm{F}\right)$ & $\begin{array}{c}.0011 \\
(3.24)\end{array}$ & $\begin{array}{c}-.0005 \\
(3.88)\end{array}$ & $\begin{array}{c}-.0002 \\
(1.87)\end{array}$ & $\begin{array}{c}.0004 \\
(1.47)\end{array}$ & $\begin{array}{c}.0002 \\
(0.60)\end{array}$ & $\begin{array}{c}-.0004 \\
(2.75)\end{array}$ & $\begin{array}{c}-.0002 \\
(1.23)\end{array}$ & $\begin{array}{c}-.0008 \\
(4.55)\end{array}$ \\
\hline $\mid$ State-Country of Birth Temp. Sq. $\mid \div 100$ & $\begin{array}{c}-.0016 \\
(1.70)\end{array}$ & $\begin{array}{c}.0037 \\
(9.63)\end{array}$ & $\begin{array}{c}.0027 \\
(8.50)\end{array}$ & $\begin{array}{c}-.0005 \\
(0.65)\end{array}$ & $\begin{array}{c}-.0008 \\
(1.08)\end{array}$ & $\begin{array}{r}.0030 \\
(8.44)\end{array}$ & $\begin{array}{r}.0024 \\
(5.50)\end{array}$ & $\begin{array}{r}.0034 \\
(6.78)\end{array}$ \\
\hline |State-Country of Birth Precip.| (inches) & $\begin{array}{c}-.0009 \\
(6.22)\end{array}$ & $\begin{array}{l}-.0006 \\
(11.31)\end{array}$ & $\begin{array}{c}-.0004 \\
(11.05)\end{array}$ & $\begin{array}{l}-.0005 \\
(5.58)\end{array}$ & $\begin{array}{c}-.0008 \\
(6.67)\end{array}$ & $\begin{array}{c}-.0005 \\
(10.50)\end{array}$ & $\begin{array}{c}-.0003 \\
(6.68)\end{array}$ & $\begin{array}{c}-.0007 \\
(10.80)\end{array}$ \\
\hline $\mid$ State-Country of Birth Precip. Sq. $\mid \div 100$ & $\begin{array}{c}.0013 \\
(6.51)\end{array}$ & $\begin{array}{c}.0005 \\
(7.75)\end{array}$ & $\begin{array}{r}.0003 \\
(6.76)\end{array}$ & $\begin{array}{c}.0005 \\
(4.13)\end{array}$ & $\begin{array}{c}.0009 \\
(5.55)\end{array}$ & $\begin{array}{r}.0005 \\
(7.22)\end{array}$ & $\begin{array}{r}.0002 \\
(2.64)\end{array}$ & $\begin{array}{r}.0004 \\
(4.35)\end{array}$ \\
\hline Pseudo- $R^{2}$ & .437 & .510 & .466 & .435 & .407 & .472 & .455 & .433 \\
\hline Number of Indi & 1,508 & 9,087 & 11,043 & 2,959 & 2,388 & 9,500 & 6,015 & 7,451 \\
\hline Number of Observations & 72,384 & 436,176 & 530,064 & 142,032 & 114,624 & 456,000 & 288,720 & 357,648 \\
\hline
\end{tabular}

Source: Author's calculations using INS and Census data.

Note: Estimated via conditional logit with robust standard errors. Choice set is 48 contiguous U.S. states. 
Table 6

Determinants of Location Choice: Employment-Based Immigrants

(own-state marginal effects, $z$-ratios in parentheses)

\begin{tabular}{|c|c|c|c|c|c|c|c|c|}
\hline \multirow[b]{2}{*}{ Variable } & \multicolumn{4}{|c|}{ Men } & \multicolumn{4}{|c|}{ Women } \\
\hline & 1971 & 1980 & 1990 & 2000 & 1971 & 1980 & 1990 & 2000 \\
\hline Expected Log(Wage) & $\begin{array}{r}.0378 \\
(4.12)\end{array}$ & $\begin{array}{c}.0191 \\
(3.13)\end{array}$ & $\begin{array}{r}.0502 \\
(5.69)\end{array}$ & $\begin{array}{c}.0521 \\
(7.14)\end{array}$ & $\begin{array}{c}.0305 \\
(2.16)\end{array}$ & $\begin{array}{r}.0416 \\
(2.97)\end{array}$ & $\begin{array}{c}.1737 \\
(10.99)\end{array}$ & $\begin{array}{r}.0364 \\
(2.54)\end{array}$ \\
\hline Unemployment Rate (\% points) & $\begin{array}{c}-.0051 \\
(6.83)\end{array}$ & $\begin{array}{c}-.0020 \\
(5.01)\end{array}$ & $\begin{array}{c}-.0085 \\
(9.25)\end{array}$ & $\begin{array}{c}-.0104 \\
(10.10)\end{array}$ & $\begin{array}{c}-.0044 \\
(4.45)\end{array}$ & $\begin{array}{c}.0009 \\
\left(\begin{array}{c}1.34)\end{array}\right.\end{array}$ & $\begin{array}{c}-.0162 \\
(7.69)\end{array}$ & $\begin{array}{c}-.0011 \\
(0.65)\end{array}$ \\
\hline Region of Birth as $\%$ of State Pop. & $\begin{array}{r}.0122 \\
(3.35)\end{array}$ & $\begin{array}{r}.0102 \\
(4.32)\end{array}$ & $\begin{array}{c}-.0015 \\
(0.89)\end{array}$ & $\begin{array}{c}-.0028 \\
(1.93)\end{array}$ & $\begin{array}{r}.0166 \\
(1.90)\end{array}$ & $\begin{array}{c}.0217 \\
(7.08)\end{array}$ & $\begin{array}{c}-.0030 \\
(1.68)\end{array}$ & $\begin{array}{c}-.0046 \\
(2.04)\end{array}$ \\
\hline Region of Birth as $\%$ of State Pop. Sq. $\div 100$ & $\begin{array}{c}-.1438 \\
(1.63)\end{array}$ & $\begin{array}{c}-.1116 \\
(2.73)\end{array}$ & 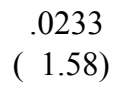 & $\begin{array}{c}.0049 \\
(0.53)\end{array}$ & $\begin{array}{c}-.2155 \\
(1.10)\end{array}$ & $\begin{array}{c}-.3795 \\
(7.93)\end{array}$ & $\begin{array}{r}.0652 \\
(4.31)\end{array}$ & $\begin{array}{r}.0320 \\
(2.46)\end{array}$ \\
\hline$\%$ of Region of Birth Pop. in State & $\begin{array}{c}.0027 \\
(8.04)\end{array}$ & $\begin{array}{c}-.0000 \\
(0.01)\end{array}$ & $\begin{array}{c}.0011 \\
(3.55)\end{array}$ & $\begin{array}{c}.0019 \\
(5.77)\end{array}$ & $\begin{array}{c}.0039 \\
(5.81)\end{array}$ & $\begin{array}{c}-.0021 \\
(5.51)\end{array}$ & $\begin{array}{c}.0007 \\
(2.15)\end{array}$ & $\begin{array}{r}.0026 \\
(4.99)\end{array}$ \\
\hline$\%$ of Region of Birth Pop. in State Sq. $\div 100$ & $\begin{array}{c}-.0049 \\
(6.98)\end{array}$ & $\begin{array}{c}-.0001 \\
(0.18)\end{array}$ & $\begin{array}{c}-.0007 \\
(1.29)\end{array}$ & $\begin{array}{c}-.0022 \\
(3.63)\end{array}$ & $\begin{array}{c}-.0085 \\
(6.18)\end{array}$ & $\begin{array}{c}.0042 \\
(6.08)\end{array}$ & $\begin{array}{c}-.0007 \\
(1.20)\end{array}$ & $\begin{array}{c}-.0036 \\
(3.99)\end{array}$ \\
\hline Foreign-Born $\%$ of State Pop. & $\begin{array}{c}.0031 \\
(3.86)\end{array}$ & $\begin{array}{c}.0006 \\
(1.10)\end{array}$ & $\begin{array}{c}.0047 \\
(10.02)\end{array}$ & $\begin{array}{c}.0022 \\
(7.25)\end{array}$ & $\begin{array}{c}.0061 \\
(4.77)\end{array}$ & $\begin{array}{c}-.0007 \\
(0.70)\end{array}$ & $\begin{array}{r}.0048 \\
(7.44)\end{array}$ & $\begin{array}{r}.0032 \\
(6.29)\end{array}$ \\
\hline Foreign-Born $\%$ of State Pop. Sq. $\div 100$ & $\begin{array}{c}-.0226 \\
(4.10)\end{array}$ & $\begin{array}{c}.0068 \\
\left(\begin{array}{c}1.92)\end{array}\right.\end{array}$ & $\begin{array}{c}-.0138 \\
(6.83)\end{array}$ & $\begin{array}{c}-.0062 \\
(5.13)\end{array}$ & $\begin{array}{c}-.0483 \\
(5.79)\end{array}$ & $\begin{array}{r}.0192 \\
(3.23)\end{array}$ & $\begin{array}{c}-.0197 \\
(6.85)\end{array}$ & $\begin{array}{c}-.0109 \\
(5.58)\end{array}$ \\
\hline Log (State Population) & $\begin{array}{c}.0192 \\
(16.27)\end{array}$ & $\begin{array}{c}.0250 \\
(22.71)\end{array}$ & $\begin{array}{c}.0231 \\
(13.93)\end{array}$ & $\begin{array}{c}.0219 \\
(18.12)\end{array}$ & $\begin{array}{c}.0310 \\
(15.40)\end{array}$ & $\begin{array}{c}.0410 \\
(18.13)\end{array}$ & $\begin{array}{r}.0432 \\
(11.61)\end{array}$ & $\begin{array}{c}.0199 \\
(10.41)\end{array}$ \\
\hline Distance from Country of Birth (1000 miles) & $\begin{array}{r}.0132 \\
(3.51)\end{array}$ & $\begin{array}{c}-.0109 \\
(5.10)\end{array}$ & $\begin{array}{l}-.0120 \\
(3.94)\end{array}$ & $\begin{array}{c}-.0039 \\
(1.39)\end{array}$ & $\begin{array}{r}.0236 \\
(3.16)\end{array}$ & $\begin{array}{c}-.0208 \\
(4.91)\end{array}$ & $\begin{array}{l}-.0213 \\
(5.25)\end{array}$ & $\begin{array}{c}-.0041 \\
(0.89)\end{array}$ \\
\hline Distance from Countryof Birth Sq. $\div 100$ & $\begin{array}{c}-.1781 \\
(6.15)\end{array}$ & $\begin{array}{c}.0367 \\
(2.18)\end{array}$ & $\begin{array}{c}.0664 \\
(2.67)\end{array}$ & $\begin{array}{c}.0035 \\
(0.16)\end{array}$ & $\begin{array}{c}-.2667 \\
(4.79)\end{array}$ & $\begin{array}{c}.0988 \\
(2.43)\end{array}$ & $\begin{array}{r}.1200 \\
(3.54)\end{array}$ & $\begin{array}{r}.0356 \\
(1.08)\end{array}$ \\
\hline Log(State Land Area) & $\begin{array}{c}-.0038 \\
(4.65)\end{array}$ & $\begin{array}{c}-.0002 \\
(0.37)\end{array}$ & $\begin{array}{c}-.0026 \\
(2.48)\end{array}$ & $\begin{array}{c}.0007 \\
(0.98)\end{array}$ & $\begin{array}{c}-.0089 \\
(6.37)\end{array}$ & $\begin{array}{c}-.0141 \\
(11.83)\end{array}$ & $\begin{array}{c}-.0016 \\
(1.21)\end{array}$ & $\begin{array}{c}-.0020 \\
(1.89)\end{array}$ \\
\hline |State-Country of Birth Temp.| $\left({ }^{\circ} \mathrm{F}\right)$ & $\begin{array}{l}-.0005 \\
(2.23)\end{array}$ & $\begin{array}{c}-.0003 \\
(1.63)\end{array}$ & $\begin{array}{c}-.0006 \\
(2.67)\end{array}$ & $\begin{array}{r}.0000 \\
(0.01)\end{array}$ & $\begin{array}{c}-.0014 \\
(3.15)\end{array}$ & $\begin{array}{c}.0008 \\
(2.66)\end{array}$ & $\begin{array}{c}-.0001 \\
(0.50)\end{array}$ & $\begin{array}{c}-.0004 \\
(1.33)\end{array}$ \\
\hline $\mid$ State-Country of Birth Temp. Sq. $\mid \div 100$ & $\begin{array}{c}.0019 \\
(3.28)\end{array}$ & $\begin{array}{c}.0023 \\
(4.70)\end{array}$ & $\begin{array}{c}.0021 \\
(2.77)\end{array}$ & $\begin{array}{c}-.0001 \\
(0.22)\end{array}$ & $\begin{array}{r}.0040 \\
(4.05)\end{array}$ & $\begin{array}{c}-.0004 \\
(0.49)\end{array}$ & $\begin{array}{c}.0008 \\
(0.90)\end{array}$ & $\begin{array}{r}.0010 \\
\left(\begin{array}{c}1.05)\end{array}\right)\end{array}$ \\
\hline |State-Country of Birth Precip.| (inches) & $\begin{array}{c}-.0009 \\
(6.96)\end{array}$ & $\begin{array}{c}-.0003 \\
(3.41)\end{array}$ & $\begin{array}{c}-.0001 \\
(1.60)\end{array}$ & $\begin{array}{l}-.0001 \\
(1.41)\end{array}$ & $\begin{array}{c}-.0006 \\
(2.62)\end{array}$ & $\begin{array}{c}-.0005 \\
(4.81)\end{array}$ & $\begin{array}{c}-.0004 \\
(4.19)\end{array}$ & $\begin{array}{c}-.0001 \\
(0.44)\end{array}$ \\
\hline $\mid$ State-Country of Birth Precip. Sq. $\mid \div 100$ & $\begin{array}{r}.0008 \\
(5.45)\end{array}$ & $\begin{array}{c}.0001 \\
\left(\begin{array}{c}1.03)\end{array}\right.\end{array}$ & $\begin{array}{c}-.0001 \\
(0.72)\end{array}$ & $\begin{array}{c}.0003 \\
(2.53)\end{array}$ & $\begin{array}{c}.0007 \\
(2.37)\end{array}$ & $\begin{array}{c}.0001 \\
(0.89)\end{array}$ & $\begin{array}{c}.0001 \\
(0.58)\end{array}$ & $\begin{array}{c}-.0001 \\
(0.38)\end{array}$ \\
\hline Pseudo- $R^{2}$ & .277 & .295 & .380 & .246 & .343 & .420 & .454 & .242 \\
\hline Number of Indi & 2,478 & 3,175 & 1,949 & 1,710 & 1,233 & 1,672 & 1,539 & 634 \\
\hline Number of Observations & 118,944 & 152,400 & 93,552 & 82,080 & 59,184 & 80,256 & 73,872 & 30,432 \\
\hline
\end{tabular}

Source: Author's calculations using INS and Census data.

Note: Estimated via conditional logit with robust standard errors. Choice set is 48 contiguous U.S. states. 
Table 7

Determinants of Location Choice: Western Hemisphere and Diversity Immigrants (own-state marginal effects, $z$-ratios in parentheses)

\begin{tabular}{|c|c|c|c|c|}
\hline \multirow[b]{3}{*}{ Variable } & \multicolumn{2}{|c|}{ Men } & \multicolumn{2}{|c|}{ Women } \\
\hline & $\begin{array}{c}\text { Western } \\
\text { Hemisphere }\end{array}$ & Diversity & $\begin{array}{c}\text { Western } \\
\text { Hemisphere }\end{array}$ & Diversity \\
\hline & 1971 & 2000 & 1971 & 2000 \\
\hline Expected Log(Wage) & $\begin{array}{c}.0096 \\
(1.54)\end{array}$ & $\begin{array}{c}.0366 \\
(5.07)\end{array}$ & $\begin{array}{c}.0510 \\
(8.41)\end{array}$ & $\begin{array}{c}.0650 \\
(5.72)\end{array}$ \\
\hline Unemployment Rate (\% points) & $\begin{array}{l}-.0097 \\
(11.39)\end{array}$ & $\begin{array}{l}-.0042 \\
(5.14)\end{array}$ & $\begin{array}{l}-.0017 \\
(3.46)\end{array}$ & $\begin{array}{l}-.0044 \\
(3.32)\end{array}$ \\
\hline Region of Birth as $\%$ of State Pop. & $\begin{array}{c}.0458 \\
(23.43)\end{array}$ & $\begin{array}{c}.0088 \\
(3.39)\end{array}$ & $\begin{array}{c}.0423 \\
(24.21)\end{array}$ & $\begin{array}{c}.0101 \\
(4.10)\end{array}$ \\
\hline Region of Birth as $\%$ of State Pop. Sq. $\div 100$ & $\begin{array}{r}-1.1533 \\
(23.07)\end{array}$ & $\begin{array}{l}-.0889 \\
(2.43)\end{array}$ & $\begin{array}{r}-1.0855 \\
(25.38)\end{array}$ & $\begin{array}{l}-.0775 \\
(2.80)\end{array}$ \\
\hline$\%$ of Region of Birth Pop. in State & $\begin{array}{l}-.0012 \\
(6.64)\end{array}$ & $\begin{array}{c}.0030 \\
(7.39)\end{array}$ & $\begin{array}{l}-.0005 \\
(3.83)\end{array}$ & $\begin{array}{c}.0026 \\
(5.28)\end{array}$ \\
\hline$\%$ of Region of Birth Pop. in State Sq. $\div 100$ & $\begin{array}{c}.0029 \\
(9.86)\end{array}$ & $\begin{array}{l}-.0041 \\
(5.59)\end{array}$ & $\begin{array}{c}.0011 \\
(5.22)\end{array}$ & $\begin{array}{l}-.0036 \\
(4.36)\end{array}$ \\
\hline Foreign-Born \% of State Pop. & $\begin{array}{c}.0062 \\
(10.91)\end{array}$ & $\begin{array}{c}.0028 \\
(9.39)\end{array}$ & $\begin{array}{c}.0058 \\
(12.84)\end{array}$ & $\begin{array}{c}.0021 \\
(5.86)\end{array}$ \\
\hline Foreign-Born $\%$ of State Pop. Sq. $\div 100$ & $\begin{array}{l}-.0086 \\
(2.20)\end{array}$ & $\begin{array}{l}-.0105 \\
(8.59)\end{array}$ & $\begin{array}{l}-.0129 \\
(4.12)\end{array}$ & $\begin{array}{l}-.0096 \\
(6.80)\end{array}$ \\
\hline Log (State Population) & $\begin{array}{c}.0196 \\
(21.81)\end{array}$ & $\begin{array}{c}.0199 \\
(16.91)\end{array}$ & $\begin{array}{c}.0193 \\
(23.56)\end{array}$ & $\begin{array}{c}.0234 \\
(14.53)\end{array}$ \\
\hline Distance from Country of Birth (1000 miles) & $\begin{array}{l}-.0243 \\
(8.75)\end{array}$ & $\begin{array}{l}-.0292 \\
(7.55)\end{array}$ & $\begin{array}{l}-.0342 \\
(12.12)\end{array}$ & $\begin{array}{l}-.0269 \\
(5.81)\end{array}$ \\
\hline Distance from Countryof Birth Sq. $\div 100$ & $\begin{array}{c}.1131 \\
(2.44)\end{array}$ & $\begin{array}{c}.1613 \\
(5.56)\end{array}$ & $\begin{array}{c}.0656 \\
(1.51)\end{array}$ & $\begin{array}{c}.1681 \\
(4.88)\end{array}$ \\
\hline Log(State Land Area) & $\begin{array}{c}.0073 \\
(14.25)\end{array}$ & $\begin{array}{c}.0005 \\
(0.53)\end{array}$ & $\begin{array}{c}.0050 \\
(11.51)\end{array}$ & $\begin{array}{r}.0018 \\
(1.43)\end{array}$ \\
\hline |State-Country of Birth Temp.| $\left({ }^{\circ} \mathrm{F}\right)$ & $\begin{array}{c}.0004 \\
(2.42)\end{array}$ & $\begin{array}{c}.0009 \\
(4.75)\end{array}$ & $\begin{array}{c}.0007 \\
(4.07)\end{array}$ & $\begin{array}{c}.0008 \\
(3.17)\end{array}$ \\
\hline $\mid$ State-Country of Birth Temp. Sq. $\mid \div 100$ & $\begin{array}{c}.0022 \\
(4.62)\end{array}$ & $\begin{array}{l}-.0008 \\
(1.54)\end{array}$ & $\begin{array}{c}.0004 \\
(0.89)\end{array}$ & $\begin{array}{l}-.0014 \\
(2.11)\end{array}$ \\
\hline |State-Country of Birth Precip.| (inches) & $\begin{array}{l}-.0005 \\
(8.68)\end{array}$ & $\begin{array}{c}-.0003 \\
(4.56)\end{array}$ & $\begin{array}{c}-.0004 \\
(7.29)\end{array}$ & $\begin{array}{l}-.0002 \\
(2.26)\end{array}$ \\
\hline $\mid$ State-Country of Birth Precip. Sq. $\mid \div 100$ & $\begin{array}{c}.0001 \\
\left(\begin{array}{c}1.61)\end{array}\right)\end{array}$ & $\begin{array}{c}.0002 \\
(2.16)\end{array}$ & $\begin{array}{c}.0003 \\
(3.74)\end{array}$ & $\begin{array}{c}.0001 \\
(0.89)\end{array}$ \\
\hline Pseudo- $R^{2}$ & .564 & .266 & .541 & .278 \\
\hline Number of Individuals & 7,851 & 3,049 & 9,913 & 2,029 \\
\hline Number of Observations & 376,848 & 146,352 & 475,824 & 97,392 \\
\hline
\end{tabular}

Source: Author's calculations using INS and Census data.

Note: Estimated via conditional logit with robust standard errors. Choice set is 48 contiguous U.S. states. 
Table 8

Determinants of Location Choice: Refugees

(own-state marginal effects, $z$-ratios in parentheses)

\begin{tabular}{|c|c|c|c|c|c|c|}
\hline \multirow[b]{2}{*}{ Variable } & \multicolumn{3}{|c|}{ Men } & \multicolumn{3}{|c|}{ Women } \\
\hline & 1971 & 1980 & 1990 & 1971 & 1980 & 1990 \\
\hline Expected Log(Wage) & $\begin{array}{c}.1585 \\
(8.81)\end{array}$ & $\begin{array}{c}.0355 \\
(6.13)\end{array}$ & $\begin{array}{c}.0398 \\
(9.13)\end{array}$ & $\begin{array}{c}.1300 \\
(8.13)\end{array}$ & $\begin{array}{c}.1359 \\
(13.23)\end{array}$ & $\begin{array}{c}.0401 \\
(4.30)\end{array}$ \\
\hline Unemployment Rate (\% points) & $\begin{array}{c}-.0016 \\
(1.37)\end{array}$ & $\begin{array}{c}-.0034 \\
(10.08)\end{array}$ & $\begin{array}{c}-.0019 \\
(5.42)\end{array}$ & $\begin{array}{c}-.0028 \\
(2.44)\end{array}$ & $\begin{array}{c}-.0086 \\
(19.52)\end{array}$ & $\begin{array}{c}-.0040 \\
(6.40)\end{array}$ \\
\hline Region of Birth as $\%$ of State Pop. & $\begin{array}{c}.0064 \\
(1.01)\end{array}$ & $\begin{array}{r}.0210 \\
(6.69)\end{array}$ & $\begin{array}{c}.0181 \\
(12.11)\end{array}$ & $\begin{array}{c}.0043 \\
(0.56)\end{array}$ & $\begin{array}{c}.0160 \\
(4.82)\end{array}$ & $\begin{array}{r}.0254 \\
(9.50)\end{array}$ \\
\hline Region of Birth as $\%$ of State Pop. Sq. $\div 100$ & $\begin{array}{c}.0069 \\
(0.06)\end{array}$ & $\begin{array}{c}-.3091 \\
(3.22)\end{array}$ & $\begin{array}{c}-.0440 \\
(2.12)\end{array}$ & $\begin{array}{c}.0672 \\
(0.51)\end{array}$ & $\begin{array}{c}-.0336 \\
(0.44)\end{array}$ & $\begin{array}{c}-.0990 \\
(2.91)\end{array}$ \\
\hline$\%$ of Region of Birth Pop. in State & $\begin{array}{c}.0040 \\
(5.34)\end{array}$ & $\begin{array}{c}.0040 \\
(16.20)\end{array}$ & $\begin{array}{c}.0000 \\
(0.20)\end{array}$ & $\begin{array}{c}.0034 \\
(3.99)\end{array}$ & $\begin{array}{c}.0025 \\
(6.96)\end{array}$ & $\begin{array}{r}.0009 \\
(2.58)\end{array}$ \\
\hline$\%$ of Region of Birth Pop. in State Sq. $\div 100$ & $\begin{array}{c}-.0093 \\
(5.34)\end{array}$ & $\begin{array}{c}-.0066 \\
(13.88)\end{array}$ & $\begin{array}{c}-.0006 \\
(1.94)\end{array}$ & $\begin{array}{c}-.0079 \\
(4.04)\end{array}$ & $\begin{array}{c}-.0037 \\
(5.84)\end{array}$ & $\begin{array}{c}-.0024 \\
(4.52)\end{array}$ \\
\hline Foreign-Born \% of State Pop. & $\begin{array}{c}.0009 \\
(0.48)\end{array}$ & $\begin{array}{c}.0004 \\
(0.87)\end{array}$ & $\begin{array}{c}-.0006 \\
(2.78)\end{array}$ & $\begin{array}{c}.0072 \\
(3.53)\end{array}$ & $\begin{array}{c}-.0017 \\
(2.76)\end{array}$ & $\begin{array}{c}-.0030 \\
(7.38)\end{array}$ \\
\hline Foreign-Born $\%$ of State Pop. Sq. $\div 100$ & $\begin{array}{c}.0058 \\
(0.46)\end{array}$ & $\begin{array}{c}-.0122 \\
(4.67)\end{array}$ & $\begin{array}{c}.0038 \\
(4.15)\end{array}$ & $\begin{array}{l}-.0419 \\
(3.02)\end{array}$ & $\begin{array}{c}-.0028 \\
(0.77)\end{array}$ & $\begin{array}{c}.0073 \\
(4.21)\end{array}$ \\
\hline Log (State Population) & $\begin{array}{c}.0125 \\
(6.41)\end{array}$ & $\begin{array}{c}.0149 \\
(22.97)\end{array}$ & $\begin{array}{r}.0160 \\
(26.66)\end{array}$ & $\begin{array}{c}.0157 \\
(7.58)\end{array}$ & $\begin{array}{c}.0125 \\
(14.04)\end{array}$ & $\begin{array}{c}.0195 \\
(17.51)\end{array}$ \\
\hline Distance from Country of Birth (1000 miles) & $\begin{array}{c}-.0711 \\
(4.08)\end{array}$ & $\begin{array}{c}.0561 \\
(12.93)\end{array}$ & $\begin{array}{c}-.0395 \\
(10.41)\end{array}$ & $\begin{array}{c}-.0596 \\
(3.42)\end{array}$ & $\begin{array}{r}.0284 \\
(4.56)\end{array}$ & $\begin{array}{c}-.0372 \\
(6.36)\end{array}$ \\
\hline Distance from Countryof Birth Sq. $\div 100$ & $\begin{array}{c}.5142 \\
(3.60)\end{array}$ & $\begin{array}{c}-.3935 \\
(13.26)\end{array}$ & $\begin{array}{c}.2652 \\
(9.57)\end{array}$ & $\begin{array}{c}.4065 \\
(2.88)\end{array}$ & $\begin{array}{c}-.2268 \\
(5.27)\end{array}$ & $\begin{array}{c}.2821 \\
(6.76)\end{array}$ \\
\hline Log(State Land Area $)$ & $\begin{array}{c}.0057 \\
(3.57)\end{array}$ & $\begin{array}{c}.0062 \\
(11.27)\end{array}$ & $\begin{array}{c}.0090 \\
(15.80)\end{array}$ & $\begin{array}{c}.0026 \\
(1.76)\end{array}$ & $\begin{array}{c}.0042 \\
(6.69)\end{array}$ & $\begin{array}{c}.0062 \\
(7.17)\end{array}$ \\
\hline |State-Country of Birth Temp.| $\left({ }^{\circ} \mathrm{F}\right)$ & $\begin{array}{c}-.0003 \\
(0.68)\end{array}$ & $\begin{array}{c}-.0007 \\
(4.35)\end{array}$ & $\begin{array}{c}-.0001 \\
(0.59)\end{array}$ & $\begin{array}{c}-.0006 \\
(1.47)\end{array}$ & $\begin{array}{l}-.0010 \\
(4.07)\end{array}$ & $\begin{array}{c}-.0008 \\
(2.80)\end{array}$ \\
\hline $\mid$ State-Country of Birth Temp. Sq. $\mid \div 100$ & $\begin{array}{r}.0000 \\
(0.01)\end{array}$ & $\begin{array}{c}.0021 \\
(4.99)\end{array}$ & $\begin{array}{c}-.0001 \\
(0.15)\end{array}$ & $\begin{array}{c}.0020 \\
(1.20)\end{array}$ & $\begin{array}{c}.0025 \\
(4.31)\end{array}$ & $\begin{array}{r}.0016 \\
(2.38)\end{array}$ \\
\hline |State-Country of Birth Precip.| (inches) & $\begin{array}{c}-.0000 \\
(0.24)\end{array}$ & $\begin{array}{c}-.0006 \\
(8.88)\end{array}$ & $\begin{array}{c}-.0002 \\
(2.51)\end{array}$ & $\begin{array}{c}-.0003 \\
(1.48)\end{array}$ & $\begin{array}{c}-.0007 \\
(8.01)\end{array}$ & $\begin{array}{c}-.0005 \\
(4.42)\end{array}$ \\
\hline $\mid$ State-Country of Birth Precip. Sq. $\mid \div 100$ & $\begin{array}{c}.0003 \\
(0.73)\end{array}$ & $\begin{array}{c}.0001 \\
(1.56)\end{array}$ & $\begin{array}{c}-.0002 \\
(1.72)\end{array}$ & $\begin{array}{c}.0007 \\
(2.05)\end{array}$ & $\begin{array}{c}.0002 \\
(1.93)\end{array}$ & $\begin{array}{r}.0002 \\
(1.22)\end{array}$ \\
\hline Pseudo- $R^{2}$ & .576 & .326 & .331 & .535 & .275 & .331 \\
\hline Number of Individuals & 2,283 & 7,477 & 8,790 & 1,432 & 4,199 & 8,790 \\
\hline Number of Observations & 109,584 & 358,896 & 421,920 & 68,736 & 201,552 & 421,920 \\
\hline
\end{tabular}

Source: Author's calculations using INS and Census data.

Note: Estimated via conditional logit with robust standard errors. Choice set is 48 contiguous U.S. states. 


\section{Appendix Table 1 \\ Skill Level Impuation \\ 1980-1990 Census Pooled Sample of Foreign-Born}

\begin{tabular}{|c|c|c|c|c|}
\hline \multirow[b]{2}{*}{ Variable } & \multicolumn{2}{|c|}{ Men } & \multicolumn{2}{|c|}{ Women } \\
\hline & Coeff. & Std. Err. & Coeff. & Std. Erro \\
\hline Southeast Asia & \multicolumn{2}{|c|}{ ref. } & \multicolumn{2}{|c|}{ ref. } \\
\hline Southwest Asia & 0.909 & 0.025 & 0.761 & 0.028 \\
\hline Africa & 0.686 & 0.032 & 0.220 & 0.032 \\
\hline East Asia & 0.260 & 0.019 & 0.147 & 0.017 \\
\hline Western Europe & 0.029 & 0.018 & -0.113 & 0.016 \\
\hline Eastern Europe & -0.177 & 0.017 & -0.233 & 0.015 \\
\hline Oceania & -0.300 & 0.044 & -0.392 & 0.038 \\
\hline Middle East & -0.325 & 0.026 & -0.436 & 0.030 \\
\hline North America & -0.385 & 0.019 & -0.392 & 0.019 \\
\hline South America & -0.387 & 0.021 & -0.434 & 0.018 \\
\hline Caribbean & -0.831 & 0.017 & -0.809 & 0.016 \\
\hline Southern Europe & -1.277 & 0.018 & -1.254 & 0.018 \\
\hline Mexico and Central America & -2.020 & 0.016 & -1.974 & 0.015 \\
\hline Writers, Artists, Entertainers and Athletes & \multicolumn{2}{|c|}{ ref. } & \multicolumn{2}{|c|}{ ref. } \\
\hline Physicians & 5.774 & 0.187 & 4.901 & 0.242 \\
\hline Lawyers & 4.728 & 0.256 & 3.373 & 0.197 \\
\hline Post-secondary teachers, Social Scientists, Librarians & 3.189 & 0.078 & 2.133 & 0.063 \\
\hline Mathematical, Computer, and Natural Scientists & 1.928 & 0.053 & 1.575 & 0.064 \\
\hline Teachers. except Post-secondary & 1.885 & 0.063 & 1.281 & 0.042 \\
\hline Engneers, Surveyors, and Archictects & 1.837 & 0.038 & 1.644 & 0.086 \\
\hline Nurses, Health Assessment, Diagnosing, and Treating & 1.605 & 0.066 & 0.574 & 0.037 \\
\hline Counselors, Social, Recreation and Religious Workers & 1.398 & 0.067 & 1.053 & 0.063 \\
\hline Executives, Administrative, and Managerial & 0.212 & 0.030 & -0.225 & 0.035 \\
\hline Technologists and Technicians & 0.192 & 0.034 & 0.026 & 0.039 \\
\hline Sales & -0.555 & 0.031 & -1.273 & 0.034 \\
\hline Administrative Support & -0.665 & 0.032 & -0.937 & 0.033 \\
\hline Precision Production, Craft, and Repair & -1.700 & 0.030 & -2.331 & 0.038 \\
\hline Service & -1.900 & 0.031 & -2.206 & 0.034 \\
\hline Laborers & -2.057 & 0.030 & -2.886 & 0.034 \\
\hline Unemployed, Out of Labor Force, Retired, Homemaker & -2.191 & 0.037 & -2.251 & 0.033 \\
\hline Farming, Forestry, and Fishing & -2.681 & 0.036 & -3.263 & 0.049 \\
\hline Age & 0.043 & 0.003 & 0.009 & 0.003 \\
\hline $\mathrm{Age}^{2}$ & -0.001 & 0.000 & -0.000 & 0.000 \\
\hline Married & -0.014 & 0.008 & 0.061 & 0.008 \\
\hline Cut Point 1 & -2.511 & 0.073 & -3.564 & 0.070 \\
\hline Cut Point 2 & 0.324 & 0.073 & -0.367 & 0.070 \\
\hline Pseudo- $R^{2}$ & \multicolumn{2}{|c|}{0.292} & \multicolumn{2}{|c|}{0.237} \\
\hline$N$ & \multicolumn{2}{|c|}{387,050} & \multicolumn{2}{|c|}{429,672} \\
\hline
\end{tabular}

Source: Authors tabulations of 1980 and 1990 IPUMS data.

Note: Estimated with ordered logit; sample limited to non-students aged 25-60. Entries in table are logit coefficients and standard errors. Dependent variable categories are: less than 12th grade, 12th-15th grade, 16th grade and higher. 